Prepared in cooperation with the National Park Service and

East Carolina University

\title{
Effect of Storms on Barrier Island Dynamics, Core Banks, Cape Lookout National Seashore, North Carolina, 1960-2001
}

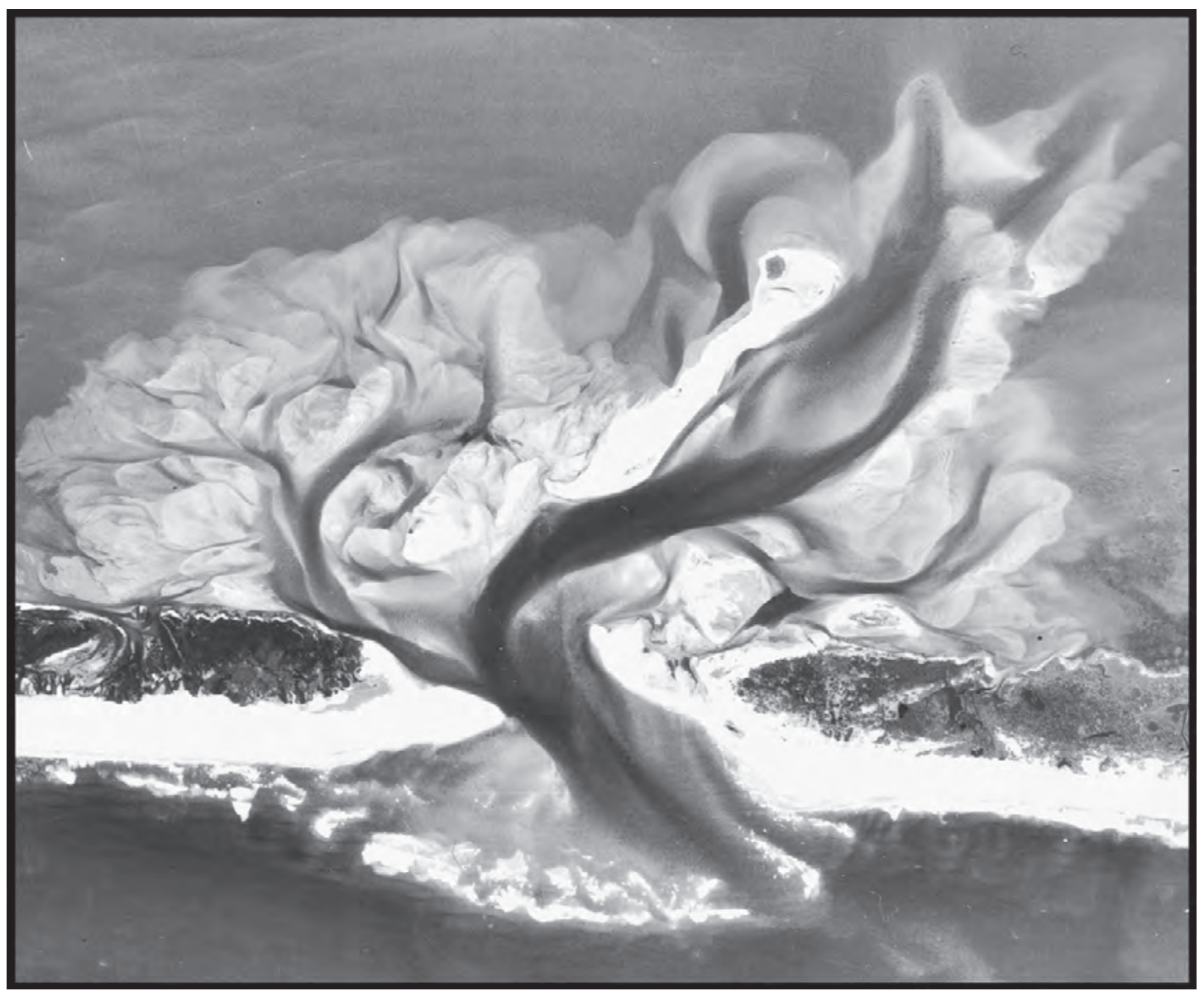

Scientific Investigations Report 2006-5309 
COVER: A 1943 aerial photograph showing Old Drum Inlet. The inlet separates North and South Core Banks and exhibits spectacular ebb- and flood-tidal deltas. This inlet provides an excellent example of island building, as the flood-tidal delta adds width and sediment volume to the back side of the barrier island. This is a crucial process for island evolution as sea-level rises and storms cause ongoing ocean shoreline recession. 
Department of Geology, East Carolina University, Greenville, NC 27858

Telephone: 252-328-6015

E-mail: riggss@ecu.edu 


\section{Effect of Storms on Barrier Island Dynamics, Core Banks, Cape Lookout National Seashore, North Carolina, 1960-2001}

By Stanley R. Riggs and Dorothea V. Ames

Prepared in cooperation with the

National Park Service and

East Carolina University

Scientific Investigations Report 2006-5309 


\section{U.S. Department of the Interior DIRK KEMPTHORNE, Secretary}

\section{U.S. Geological Survey \\ Mark D. Myers, Director}

\section{U.S. Geological Survey, Reston, Virginia: 2007}

For product and ordering information:

World Wide Web: http://www.usgs.gov/pubprod

Telephone: 1-888-ASK-USGS

For more information on the USGS — the Federal source for science about the Earth, its natural and living resources, natural hazards, and the environment:

World Wide Web: http://www.usgs.gov

Telephone: 1-888-ASK-USGS

Any use of trade, product, or firm names is for descriptive purposes only and does not imply endorsement by the U.S. Government.

Although this report is in the public domain, permission must be secured from the individual copyright owners to reproduce any copyrighted materials contained within this report.

Suggested citation:

Riggs, S.R., and Ames, D.V., 2007, Effect of storms on barrier island dynamics, Core Banks, Cape Lookout National Seashore, North Carolina, 1960-2001: U.S. Geological Survey Scientific Investigations Report 2006-5309, 73 p. 


\section{Contents}

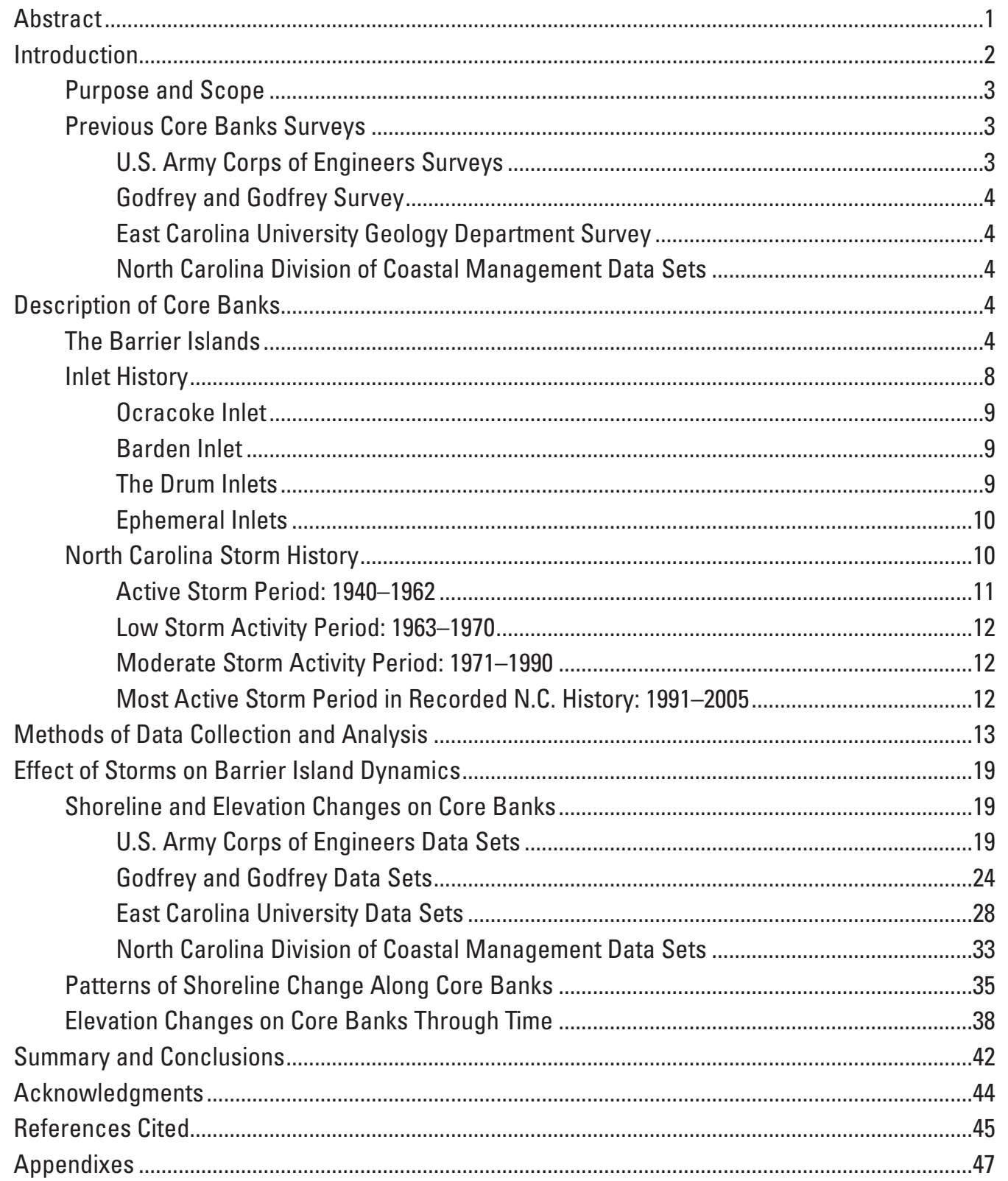




\section{Figures}

1. A regional satellite image showing the location of the Core Banks study area in the North Carolina coastal system.....

2-4 Aerial photos of-

2. A four-part, georeferenced aerial photograph time series (A, 1940; B, 1962; C, 1998; and D, 2003) showing the evolution of Old Drum Inlet, New Drum Inlet, and New-Old Drum Inlet, Cape Lookout National Seashore, North Carolina

3. A three-part aerial photograph time series (A, 1940; B, 1962; and C, 1983) showing the Portsmouth Village Overwash Plain with Whalebone and Swash Inlets on the southwestern part of the photographs, Core Banks, Cape Lookout National Seashore, North Carolina.

4. A five-part aerial photograph time series (A, 1866; B, 1933-1937; C, 1940; D, 1962; and $E$, 1998) showing Cape Lookout, Cape Lookout Bight, and Barden Inlet, North Carolina

5. Graph showing total number of hurricane strikes in North Carolina by decade for the period from 1900 to 1999 .

6. Diagrams showing the 77 profiles and associated topographic and bathymetric surveys done from 1960 to 1962 by the U.S. Army Corps of Engineers (USACE) on North Core Banks (A), and South Core Banks (B), Cape Lookout National Seashore, North Carolina .

7. Diagrams showing the layout of reference markers (RMs) developed for the (A) 1960 to 1962 surveys and (B) 2001 survey of North and South Core Banks, Cape Lookout National Seashore, North Carolina and the methods used in 2001 to determine shoreline and elevation changes.

8. Photographs showing relocated U.S. Army Corps of Engineers 1960-1962 reference markers (RM) on Core Banks, Cape Lookout National Seashore, North Carolina ..........16

9. Diagram showing the 57 profiles located by the 2001 East Carolina University survey of the original 77 profiles established by the U.S. Army Corps of Engineers on North and South Core Banks, Cape Lookout National Seashore, North Carolina

10. Schematic diagrams showing the method used by the U.S. Army Corps of Engineers, Godfrey and Godfrey, and East Carolina University to determine shoreline changes in their 1960 (A) 1961, 1962 (B) 1971, and 2001 (C), shoreline surveys, Core Banks, Cape Lookout National Seashore, North Carolina

11-16 Histograms showing-

11. Net shoreline change data for 77 profiles by the U.S. Army Corps of Engineers between the 1960 and 1961 surveys (blue) and the 1961 and 1962 surveys (red), Core Banks, Cape Lookout National Seashore, North Carolina .....

12. Average annual rate of shoreline change for the 77 profiles between the U.S. Army Corps of Engineers 1960 and 1961 surveys (blue) and the 1961 and 1962 surveys (red), Core Banks, Cape Lookout National Seashore, North Carolina.......22

13. Horizontal distance from the shoreline to the 6-, 12-, 18-, 24-, and 30-foot depth contours for alternate profiles from the U.S. Army Corps of Engineers 1961 survey, Core Banks, Cape Lookout National Seashore, North Carolina ...

14. Horizontal distance from the shoreline seaward to the 6-, 12-, 18-, 24-, and 30-foot depth contours for alternate profiles from the U.S. Army Corps of Engineers 1961 survey, plotted opposite the long-term NCDCM 1946-1998 average annual shoreline erosion rates in feet per year for Core Banks, Cape Lookout National Seashore, North Carolina. 
15. Average rate of shoreline change between the USACE 1962 survey and Godfrey and Godfrey 1971 survey for Core Banks, Cape Lookout National Seashore, North Carolina

16. Average annual rate of shoreline erosion and accretion from the U.S.

Army Corps of Engineers 1960-1962 survey data (red) and the Godfrey and Godfrey 1962-1971 survey data (blue), Core Banks, Cape Lookout National Seashore, North Carolina

17. Cross-sectional profile of South Core Banks at Codds Creek showing the shallow stratigraphic interpretation of the history of overwash fan deposition developed from a series of trenches dug across the island.

18-23 Histograms showing-

18. Net shoreline change (red) and average annual rate of change (blue) from the East Carolina University 1960-2001 survey for each profile where the U.S. Army Corps of Engineers reference markers were recovered, Core Banks, Cape Lookout National Seashore, North Carolina

19. Average annual rate of shoreline change from the U.S. Army Corps of Engineers 1960-1962 surveys for the 77 USACE profiles and the East Carolina University 1960-2001 survey for the 57 profiles where one or more of the U.S. Army Corps reference markers were recovered, Core Banks, Cape Lookout National Seashore, North Carolina

20. Average annual rate of shoreline change from the Godfrey and Godfrey 1962-1971 survey and the East Carolina University 1960-2001 survey, Core Banks, Cape Lookout National Seashore, North Carolina

21. Net increase in ground elevation at U.S. Army Corps of Engineers reference markers based on changes between the U.S. Army Corps of Engineers 1961 and East Carolina University 2001 surveys for each profile where U.S. Army Corps of Engineers reference markers were recovered, Core Banks, Cape Lookout National Seashore, North Carolina.

22. Shoreline change data from the North Carolina Division of Coastal Management 1940-1992 and 1946-1998 data sets, Core Banks, Cape Lookout National Seashore, North Carolina

23. Average annual rate of shoreline change from the long-term East Carolina University 1960-2001 data set and the long-term North Carolina Division of Coastal Management 1946-1998 data set, Core Banks, Cape Lookout National Seashore, North Carolina

24. Aerial photographs showing specific features that are relevant to the dynamics of shoreline change, Core Banks, Cape Lookout National Seashore, North Carolina ........37

25. Histogram showing elevation changes measured by the Godfrey and Godfrey 1970 and East Carolina University 2001 surveys as compared to the U.S. Army Corps of Engineers survey when the reference markers were installed on 77 profiles, Core Banks, Cape Lookout National Seashore, North Carolina..

26. A five-part, aerial photograph, time-slice sequence showing the Swash Inlet to Whalebone Inlet segment of North Core Banks, Cape Lookout National Seashore, North Carolina

27. Photographs showing changes with time on Core Banks, Cape Lookout National Seashore, North Carolina. 


\section{Tables}

1. Maximum and average annual rates of shoreline erosion and accretion for each of the shoreline survey data sets for North and South Core Banks combined, Cape Lookout National Seashore, North Carolina

2. Summary of the elevation data for 231 reference markers on 77 profiles from the 1961 U.S. Army Corps of Engineers survey for Core Banks, Cape Lookout National Seashore, North Carolina

3. Summary of the elevation data for 141 reference markers on 69 profiles from the 1970 Godfrey and Godfrey survey for Core Banks, Cape Lookout National Seashore, North Carolina

4. Summary of the elevation data for 83 reference markers on 57 profiles from the East Carolina University 2001 survey for Core Banks, Cape Lookout National Seashore, North Carolina ...... 33

5. Maximum and average annual rates of shoreline erosion and accretion for each of the shoreline surveys or data sets for North and South Core Banks, Cape Lookout National Seashore, North Carolina.

6. Summary of net ground elevation and percent change data for all reference markers from surveys by the U.S. Army Corps of Engineers, Godfrey and Godfrey, and East Carolina University for Core Banks, Cape Lookout National Seashore, North Carolina ....

\section{Appendixes}

1. Summary of the U.S. Army Corps of Engineers survey data developed in the 1960, 1961, and 1962 surveys on Core Banks, Cape Lookout National Seashore, North Carolina

2. Summary of the U.S. Army Corps of Engineers 1961 survey data of the shoreface bathymetry for Core Banks, Cape Lookout National Seashore, North Carolina

3. Summary of the Godfrey and Godfrey 1970 survey data of elevation change along 69 of the 77 U.S. Army Corps of Engineers profiles on Core Banks, Cape Lookout National Seashore, North Carolina.

4. Summary of the Godfrey and Godfrey 1971 survey data of shoreline change along 39 of the 77 U.S. Army Corps of Engineers profiles on Core Banks, Cape Lookout National Seashore, North Carolina

5. Latitude and longitude locations for the recovered U.S. Army Corps of Engineers reference markers that were located and surveyed in 2001 by East Carolina University for the present study on Core Banks, Cape Lookout National Seashore, North Carolina .

6. Summary of the East Carolina University survey data for 57 of the 77 U.S. Army Corps of Engineers profiles located in the 2001 survey on Core Banks, Cape Lookout National Seashore, North Carolina.

7. Summary of the North Carolina Division of Coastal Management shoreline recession data (1940-1992 and 1946-1998) for the average annual shoreline erosion rates on Core Banks, Cape Lookout National Seashore, North Carolina 


\title{
Conversion Factors and Datums
}

\begin{tabular}{|c|c|c|}
\hline Multiply & By & To obtain \\
\hline \multicolumn{3}{|c|}{ Length } \\
\hline inch (in.) & 25.4 & millimeter $(\mathrm{mm})$ \\
\hline foot $(\mathrm{ft})$ & 0.3048 & meter $(\mathrm{m})$ \\
\hline mile (mi) & 1.609 & kilometer $(\mathrm{km})$ \\
\hline \multicolumn{3}{|c|}{ Area } \\
\hline acre & 0.4047 & hectare (ha) \\
\hline square foot $\left(\mathrm{ft}^{2}\right)$ & 0.09290 & square meter $\left(\mathrm{m}^{2}\right)$ \\
\hline
\end{tabular}

Vertical coordinate information is referenced to the National Geodetic Vertical Datum of 1929 (NGVD 29).

Horizontal coordinate information is referenced to the World Geodetic System 1984 (WGS 84).

Altitude, as used in this report, refers to distance above the vertical datum.

\section{Abbreviations}

\author{
CAHA Cape Hatteras National Seashore \\ CALO Cape Lookout National Seashore \\ ECU East Carolina University \\ G\&G Godfrey and Godfrey \\ NCDCM North Carolina Division of Coastal Management \\ NPS U.S. National Park Service \\ NPS-GRI U.S. National Park Service-Geologic Resources Inventory \\ NCGS North Carolina Geological Survey \\ USACE U.S. Army Corps of Engineers \\ USGS U.S. Geological Survey \\ D000 Digital orthophoto quarter quadrangle \\ GIS Geographic Information Systems \\ MLW Mean low water \\ MSL Mean sea level \\ P Profile number (e.g., P17) \\ RM Reference marker number (e.g., RM-0)
}





\title{
Effect of Storms on Barrier Island Dynamics, Core Banks, Cape Lookout National Seashore, North Carolina, 1960-2001
}

\author{
by Stanley R. Riggs and Dorothea V. Ames
}

\section{Abstract}

The effect of storms on long-term dynamics of barrier islands was evaluated on Core Banks, a series of barrier islands that extend from Cape Lookout to Okracoke Inlet in the Cape Lookout National Seashore, North Carolina. Shoreline and elevation changes were determined by comparing 77 profiles and associated reference markers established by the U.S. Army Corps of Engineers (USACE) on Core Banks from June 1960 to July 1962 to a follow-up survey by Godfrey and Godfrey (G\&G) in 1971 and a survey by the Department of Geology at East Carolina University (ECU) in 2001, in which 57 of the original 77 profiles were located.

Evaluation of the baseline data associated with the USACE study supplies an important record of barrier island response to two specific storm events-Hurricane Donna in September 1960 and the Ash Wednesday extra-tropical cyclone in March 1962. The 1962 USACE survey was followed by 9 years characterized by no major storms; this low-energy period was captured by the G\&G survey in 1971 . The G\&G survey was followed by 22 years characterized by occasional small to moderate storms. Starting in 1993, however, and continuing through 1999, the North Carolina coast experienced a major increase in storm activity, with seven major hurricanes impacting Core Banks.

Both the USACE 1960-1962 and G\&G 1962-1971 surveys produced short-term data sets that reflected very different sets of weather conditions. The ECU 2001 survey data were then compared with the USACE 1960 survey data to develop a long-term (41 years) data set for shoreline erosion on Core Banks. Those resulting long-term data were compared with the long-term (52 years) data sets by the North Carolina Division of Coastal Management (NCDCM) from 1940-1992 and 1946-1998; a strong positive correlation and very similar rates of average annual erosion resulted. However, the ECU and NCDCM long-term data sets did not correlate with either of the USACE and G\&G short-term survey data and had very different average annual erosion rates.

The average annual long-term rate of shoreline erosion for all of Core Banks and for both the ECU 1960-2001 and the NCDCM 1946-1998 surveys was -5 feet per year (ft/yr).
These long-term rates of shoreline recession are in strong contrast with the short-term, storm-dominated rates of shoreline erosion for all of Core Banks developed by the USACE 1960-1961 and USACE 1961-1962 surveys, which have average annual erosion rates of $-40 \mathrm{ft} / \mathrm{yr}$ and $-26 \mathrm{ft} / \mathrm{yr}$, respectively, and range from -226 feet (ft) to $+153 \mathrm{ft}$. The combined shortterm, storm-dominated shoreline erosion rate for the USACE surveys (1960-1962) was - $36 \mathrm{ft} / \mathrm{yr}$. In contrast, the average annual short-term, non-stormy period G\&G 1962-1971 survey demonstrated shoreline accretion for all of Core Banks with an average annual rate of $+12 \mathrm{ft} / \mathrm{yr}$. In general, North Core Banks has higher erosion and accretion rates than South Core Banks.

In the 1961 survey, the USACE installed 231 reference markers (RM-0 is closest to the ocean and RM-2 is farthest from the ocean) along the 77 profiles, as well as 33 reference markers labeled RM-4, RM-6, and RM-8 in the wider portions of the islands. The G\&G survey recovered a total of 141 reference markers ( 61 percent), and the ECU survey recovered a total of 83 reference markers (36 percent) of the RM- 0 , RM-1, and RM-2 markers. The average ground elevation measured by the USACE in 1961 was RM- $0=+5.8 \mathrm{ft}$, RM- $1=$ $+5.2 \mathrm{ft}$, and $\mathrm{RM}-2=+4.8 \mathrm{ft}$. The G\&G 1970 survey measured average ground elevations of RM- $0=+6.7 \mathrm{ft}, \mathrm{RM}-1=+6.4$ $\mathrm{ft}$, and $\mathrm{RM}-2=+6.1 \mathrm{ft}$, and the average ground elevation measured by ECU in 2001 was RM- $0=+10.1 \mathrm{ft}, \mathrm{RM}-1=$ $+9.1 \mathrm{ft}$, and $\mathrm{RM}-2=+8.5 \mathrm{ft}$. The latter numbers represent approximately an overall 72-percent increase in island elevation from 1961 to 2001. Based on aerial photographic time-slice analyses, it is hypothesized that this increase in island elevation occurred during the post-1962 period with storm overwash systematically raising the island elevation through time, which in turn led to decreased numbers of overwash events. The latter processes and responses in turn led to a substantial increase in vegetative growth on the barrier island, as well as submerged aquatic vegetation on the backbarrier sand shoals.

Integration of the USACE, G\&G, ECU, and NCDCM shoreline erosion data for Core Banks shows several important points about shoreline recession. 


\section{Effect of Storms on Barrier Island Dynamics, Core Banks, Cape Lookout National Seashore, North Carolina, 1960-2001}

(1) The ECU and NCDCM data sets demonstrate that there is an ongoing net, long-term, but small-scale shoreline recession associated with Core Banks; (2) the USACE short-term data sets demonstrate that processes associated with individual storm events or sets of events produce extremely large-scale changes that include both erosion and accretion; (3) the shortterm, non-stormy period data set of G\&G demonstrates that if given enough time between storm events, barriers can rebuild to their pre-storm period conditions; and (4) the post-storm response generally tends to approach the pre-storm location, but rarely reaches it before the next storm or stormy period sets in. The result is the net long-term change documented by both the ECU 1960-2001 and NCDCM 1946-1998 Core Banks data sets that resulted in erosion rates ranging from 0 to $-30 \mathrm{ft} / \mathrm{yr}$ with net annual average recession rates of $-5 \mathrm{ft} / \mathrm{yr}$.

Analysis and comparison of these data sets supply important information for understanding the dynamics and responses of barrier island systems through time. In addition, the results of the present study on Core Banks supply essential process-response information that can be used to design and implement management plans for the Cape Lookout and Cape Hatteras National Seashores and for other seashores in the U.S. National Park Service system.

\section{Introduction}

A program to study the coastal geology of North Carolina was begun in 2000 as a cooperative effort between the U.S. Geological Survey (USGS), East Carolina University (ECU), and the North Carolina Geological Survey (NCGS). The program, known as the Coastal Geology Research Cooperative Program, covers the coastal region from Currituck County and Currituck Sound, south to Cape Lookout and Core Sound. The region extends from the inner shelf, across the barrier islands, and through the shallow back-barrier estuarine system. Primary goals of the program are to investigate the roles that the underlying geologic framework, climate change, and sealevel fluctuations play in the dynamics of coastal evolution and behavior. Field data collection includes seismic, sidescan, ground-penetrating radar and swath bathymetry surveys; vibracoring in marine and estuarine waters and conventional core drilling on the barrier islands and mainland; geologic and aerial photographic mapping of stratigraphic, sedimentologic, geomorphic, and ecologic data; textural and geochemical analyses of the sediment facies and depositional environments; and microfaunal and age-date analyses of the Holocene and Pleistocene lithofacies.

Concurrently, the Geologic Resources Division (GRD) and Inventory and Monitoring Program (I\&M), both programs of the U.S. National Park Service (NPS), are required to develop digital geologic map coverage for use in Geographic Information Systems (GIS). Cape Hatteras (CAHA) and Cape Lookout (CALO) National Seashores are two natural resource units in North Carolina for which this coverage, called the Geologic Resources Inventory (GRI), is required. Both of these seashores consist of a series of offshore barrier islands that constitute a major portion of North Carolina's Outer Banks. On April 3-5, 2000, the GRI team held a field trip and scoping meeting in Manteo, N.C., with members of the Coastal Geology Research Cooperative group to evaluate the two National Seashores. During the course of the meeting, NPS, USGS, ECU, and NCGS, along with other coastal experts, evaluated the parks and determined that existing geologic information was not suitable to meet future park needs nor to compile a GRI for these parks.

Previous work on Core Banks included surveys by the U.S. Army Corps of Engineers (USACE) and Godfrey and Godfrey (G\&G). The USACE surveyed Core Banks three times from 1960 to 1962. The first survey was done in June 1960, but many reference markers were destroyed by Hurricane Donna on September 12, 1960. The missing reference markers were replaced and resurveyed from September to December 1961. Many reference markers again were destroyed, this time by the Ash Wednesday extratropical cyclone in March 1962. The USACE re-established the missing reference markers, added an additional set of reference markers along each profile, and resurveyed all reference markers for the third time from June to July 1962. In 1970, G\&G located 141 of the USACE reference markers and measured the change in elevation since they were installed. G\&G also resurveyed the 1971 shoreline location along 39 of the original 77 USACE profiles. The G\&G surveys took place during the summers of 1970 and 1971.

According to Barnes (2001), no major storms directly impacted Core Banks between the USACE 1962 survey and the G\&G surveys; however, Hurricane Ginger made landfall near Cape Lookout in October 1971. Based partly upon this storm, Dolan and Godfrey (1973) and Godfrey and Godfrey (1976) determined that storm overwash was a critical process for both island migration in response to rising sea level, as well as a major control of the plant community structure. Today, Core Banks is no longer dominated by overwash processes such as those that occurred during the pre-1971 period. The islands are heavily vegetated, and there has been only partial island overwash in spite of seven hurricanes that made landfall in North Carolina during 1993-1999. Why has this major change taken place? Is this a response to a change in climate, sea level, sediment supply, human modification, NPS management policies, or some combination thereof?

Dr. Michael Rikard, Resource Management Specialist for Cape Lookout National Seashore, stated that "relocating and resurveying the 1960 to 1962 Core Banks reference markers and evaluating the morphological and ecological changes that have occurred since the initial USACE surveys represents an important research priority for Cape Lookout National Seashore." To evaluate the evolutionary changes happening on Core Banks since the USACE initial survey, and to generate 
information needed for the GRI, NPS contracted with the ECU Geology Department, in concert with the USGS and NCGS to undertake the Core Banks study. The primary objective was to carry out an evaluation of barrier island processes operating over a 41-year time period based on changes along the 77 permanent profiles established by the USACE on Core Banks between Cape Lookout and Ocracoke Inlet. The NPS research needs match the overall goals and objectives of the Coastal Geology Research Cooperative Program and represent an important component of the overall study of coastal systems in North Carolina.

\section{Purpose and Scope}

This report is a product of the Coastal Geology Research Cooperative Program and is designed to help meet the NPSGRI goal of obtaining digital geologic maps for the Core Banks part of the Cape Lookout National Seashore. The report describes the study by ECU and includes an evaluation of barrier island processes based on changes along 77 profiles and associated reference markers established by the USACE on Core Banks from June 1960 to July 1962. The study area extends from Cape Lookout to Ocracoke Inlet and includes both North and South Core Banks. The ECU Core Banks evaluation is built upon the initial surveys of the USACE (1964), the follow-up survey and ecological work by Godfrey and Godfrey (1976), and the ongoing study by the Department of Geology at ECU. The report includes results of the 2001 ECU field survey and the analysis of changes that have occurred through time on Core Banks since the initial USACE survey in 1960 .

\section{Previous Core Banks Surveys}

\section{U.S. Army Corps of Engineers Surveys}

In light of severe hurricane damage to coastal and tidal areas in the eastern and southern United States, the 84th Congress passed Public Law 71 on June 15, 1955 that gave the USACE the responsibility of undertaking the following studies on Portsmouth Island and Core Banks of North Carolina.

1. Hurricane Study to (a) analyze hurricane damage and the cause factors, (b) appraise hurricane effects in terms of preventable damages, and (c) develop practical solutions.

2. Beach Erosion Control Study to determine the feasibility of developing practical and economical means of (a) maintaining the shoreline, (b) rebuilding badly eroded areas, and (c) preventing further degradation of the existing Outer Banks topography.

In response to Congress, the USACE carried out three important shoreline surveys between Cape Lookout and Ocracoke Inlet, Cape Lookout National Seashore, in 1960, 1961, and 1962. In June 1960, the USACE established and surveyed 77 shore-perpendicular profiles along the length of
Core Banks; however, many profiles established in the first survey were destroyed by Hurricane Donna on September 12,1960 . The destroyed profiles were replaced, along with a series of reference markers established along the 77 profiles, and surveyed from September to December 1961. Both the profiles and reference markers were partially destroyed again by the Ash Wednesday extra-tropical cyclone in March 1962. The USACE replaced and resurveyed all destroyed profiles and reference markers for the third time from June to July 1962. The relevant USACE data are presented in appendixes 1 and 2.

Results of these surveys were published in two parts in the USACE (1964) report that included the Hurricane Survey Report from Ocracoke Inlet to Beaufort Inlet, North Carolina and the Beach Erosion Report from Ocracoke Inlet to Cape Lookout. The USACE (1964) study recommended the following shore- and hurricane-protection plan for 51.4 miles (mi) of the Core Banks ocean shoreline.

1. The beach fill would have a constructed berm that is 50 feet (ft) wide and $8 \mathrm{ft}$ above mean sea level (MSL) and a dune with a crest width of $25 \mathrm{ft}$ and elevation of $12 \mathrm{ft}$ above MSL.

2. The dune crest would be topped by a 4-ft sand fence.

3. The shoreline would be stabilized by periodic nourishment.

4. An estimated construction cost was $\$ 5.8$ million with an annual maintenance cost of $\$ 481,200$.

5. An adjunct portion of this plan was to evaluate the possibility of stabilizing, deepening, and widening the channel of Drum Inlet.

At the same time, the U.S. Congress (House Document 408, 86th Congress, 2d session) and the USACE were recommending that the Ocracoke Inlet channel be dredged to $18 \mathrm{ft}$ below MSL with a 400-ft width and provisions for construction of a jetty on the Ocracoke Island side to help maintain the channel. The USACE stated that these latter projects would have adverse erosion effects on the Portsmouth shoreline and therefore would require the proposed plan for the down-drift beaches of Core Banks be undertaken.

No portion of the USACE plan was ever implemented; however, from 1961 through at least 1964, experimental dune-building studies were carried out by the State of North Carolina and the USACE over $4 \mathrm{mi}$ of shore northeast of Old Drum Inlet. Subsequently, during the 1970s, NC State University carried out extensive sand fencing and grassplanting studies. Also, when Drum Inlet closed naturally in January 1971, the USACE artificially opened New Drum Inlet in December 1971 about $2.8 \mathrm{mi}$ southwest of the Old Drum Inlet site. Then, in September 1999, Hurricane Dennis came ashore across Core Banks and reopened Old Drum Inlet, which is now called New-Old Drum Inlet. 


\section{Godfrey and Godfrey Survey}

Godfrey and Godfrey were contracted by the National Park Service to resurvey the 1962 USACE profiles, as well as map the geomorphic features of Core Banks and determine the major plant communities and their distribution (1976). In 1970, they located 141 of the original 231 reference markers installed by the USACE in 1962 and measured the change in elevation (appendix 3). In 1971, they used 39 of the original 77 USACE profiles and surveyed the 1971 shoreline location. The G\&G shoreline recession data for 1962-1971 are presented in appendix 4.

\section{East Carolina University Geology Department Survey}

The 2001 ECU survey of Core Banks was conducted in partnership with the Coastal Geology Research Cooperative Program and is presented in this report. The ECU survey located 83 of the original 231 reference markers installed along 57 of the 77 USACE profiles. The latitude and longitude of the 83 reference markers are presented in appendix 5 . The change in ground elevation since their installation was measured and is recorded in appendix 6. Reference markers along 57 of the original 77 USACE profiles were used to survey the 2001 shoreline location (appendix 6). Twenty profiles had no data recovered because the reference markers were either eroded by the sea, deeply buried in sand, or destroyed by people. Physical surveys were integrated with time-slice aerial photographic analysis to provide understanding and interpretations of horizontal and vertical landscape change and vegetation community succession through time.

\section{North Carolina Division of Coastal Management Data Sets}

The North Carolina Division of Coastal Management (NCDCM) developed two long-term shoreline erosion data sets for the entire North Carolina ocean shoreline based on the "end-point" method of aerial photographic analysis (Benton and others, 1993; Benton and others, 1997). The Core Banks portion of the two long-term shoreline erosion data sets, NCDCM 1940-1992 and 1946-1998, are summarized in appendix 7 . This shoreline recession data set was obtained using a different method than the data sets based on the USACE, G\&G, and ECU surveys described in this report. The NCDCM long-term data are used as a cross check for the ECU 1960-2001 long-term data. Although they represent somewhat different time periods and different survey methods, the data produced similar results.

\section{Description of Core Banks}

\section{The Barrier Islands}

Core Banks, located in Raleigh Bay, extends about $45 \mathrm{mi}$ from Ocracoke Inlet on the northeast to Cape Lookout on the southwest and then $3.4 \mathrm{mi}$ northwest to Cape Lookout Bight and Barden Inlet (fig. 1). Core Banks is separated from the mainland by the narrow and shallow waters of Core Sound (fig. 1), which are named for the Coree Indians. At the time of English settlement in 1585, the Coree Indians lived on the mainland and used the Banks extensively to obtain food. Core Banks were described by Holland (1968) as "a thin strip of land, hardly more than an overgrown sandbar with marsh grass and some low-growing bushes." The USACE report (1964) described Core Banks as follows: "Most of the topography is unstable. Dunes form, only to be breached by storms; inlets open, migrate, and close; and both seasonal and long-term changes occur in the ocean shoreline."

The Banks form an arcuate coastal system that has a general northeast-southwest orientation and consists of North, Middle, and South Core Bank components (fig. 2). Middle Core Banks is a small island segment (about $2.5 \mathrm{mi}$ ) separated from the 20.3-mi long North Core Banks by New-Old Drum Inlet and the 22.2-mi long South Core Banks by New Drum Inlet (fig. 2). Both of these small inlets are open today, have an active tidal exchange, and have main channels that are up to $10 \mathrm{ft}$ deep and shallow bars adjacent to the berm crest on the adjoining islands that can be readily crossed during low tides. 


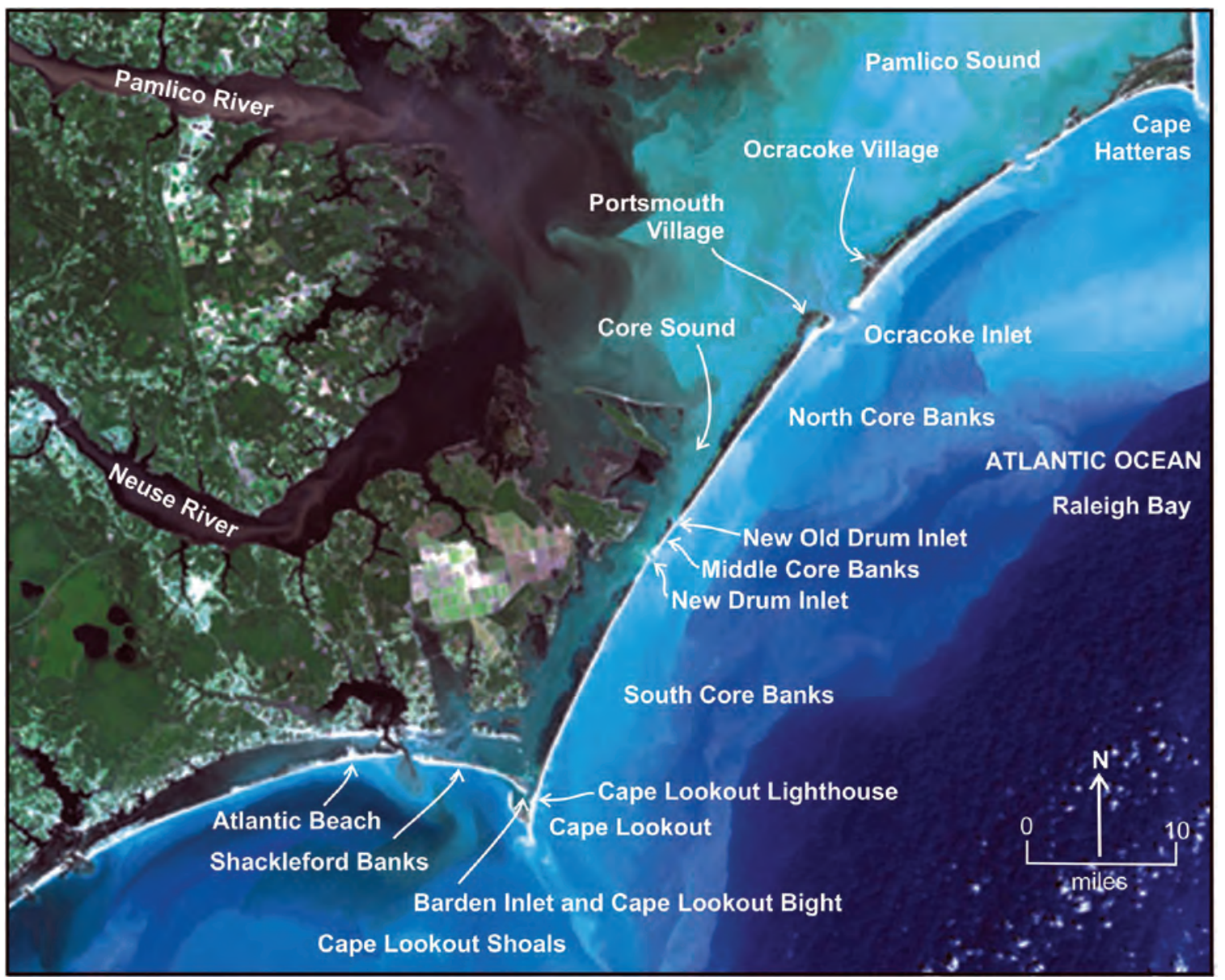

Figure 1. A regional satellite image showing the location of the Core Banks study area in the North Carolina coastal system. 

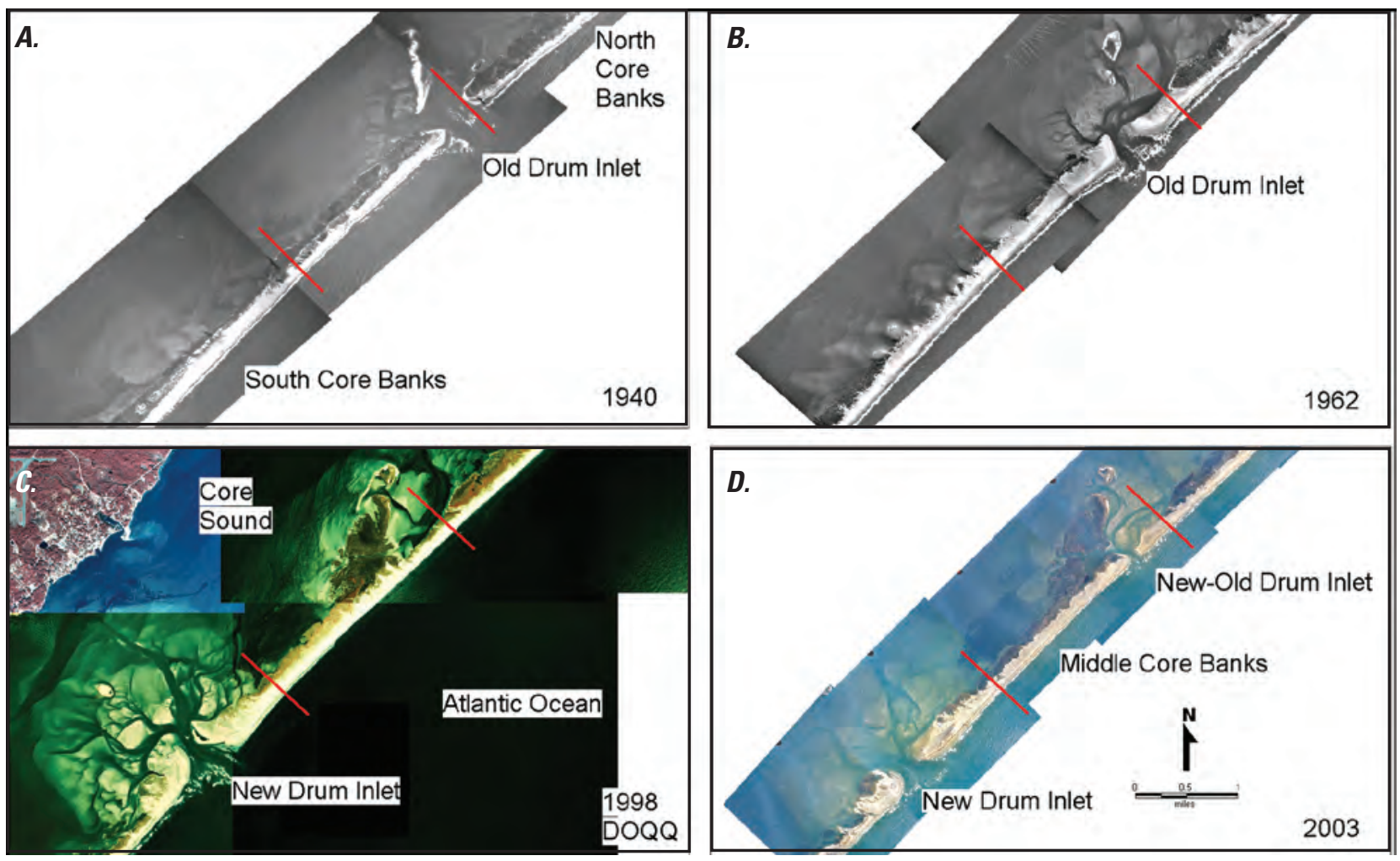

Figure 2. A four-part, georeferenced aerial photograph time series $(A, 1940 ; B, 1962 ; C, 1998$; and $D, 2003)$ showing the evolution of Old Drum Inlet, New Drum Inlet, and New-Old Drum Inlet, Cape Lookout National Seashore, North Carolina. The red reference lines represent two fixed positions associated with each of the inlet locations through time. The 1940 and 1962 panels show Old Drum Inlet that opened in a 1933 hurricane and built a flood-tide delta through time (see Cover Photo). The inner bar of Old Drum Inlet was dredged six times on an irregular basis beginning in 1939 until 1952. Notice the major dredge spoil island directly behind the throat of the inlet in 1940. The inlet narrowed significantly by 1957 and began a rapid southwestward migration as evidenced by the location of the channel relative to the remnant dredge spoil islands and the major development of a prograding spit on the northeast side of the inlet. The 1998 panel shows the Old Drum Inlet, which closed naturally in January 1971 with marsh now growing over much of the flood-tide delta sand shoals, and New Drum Inlet that was opened artificially by the USACE in December 1971. Notice the very extensive and beautifully developed flood-tide delta associated with New Drum Inlet. The 2003 post-Hurricane Isabel panel shows the southwest migration of New Drum Inlet and the New-Old Drum Inlet that was reopened by Hurricane Dennis in 1999. 


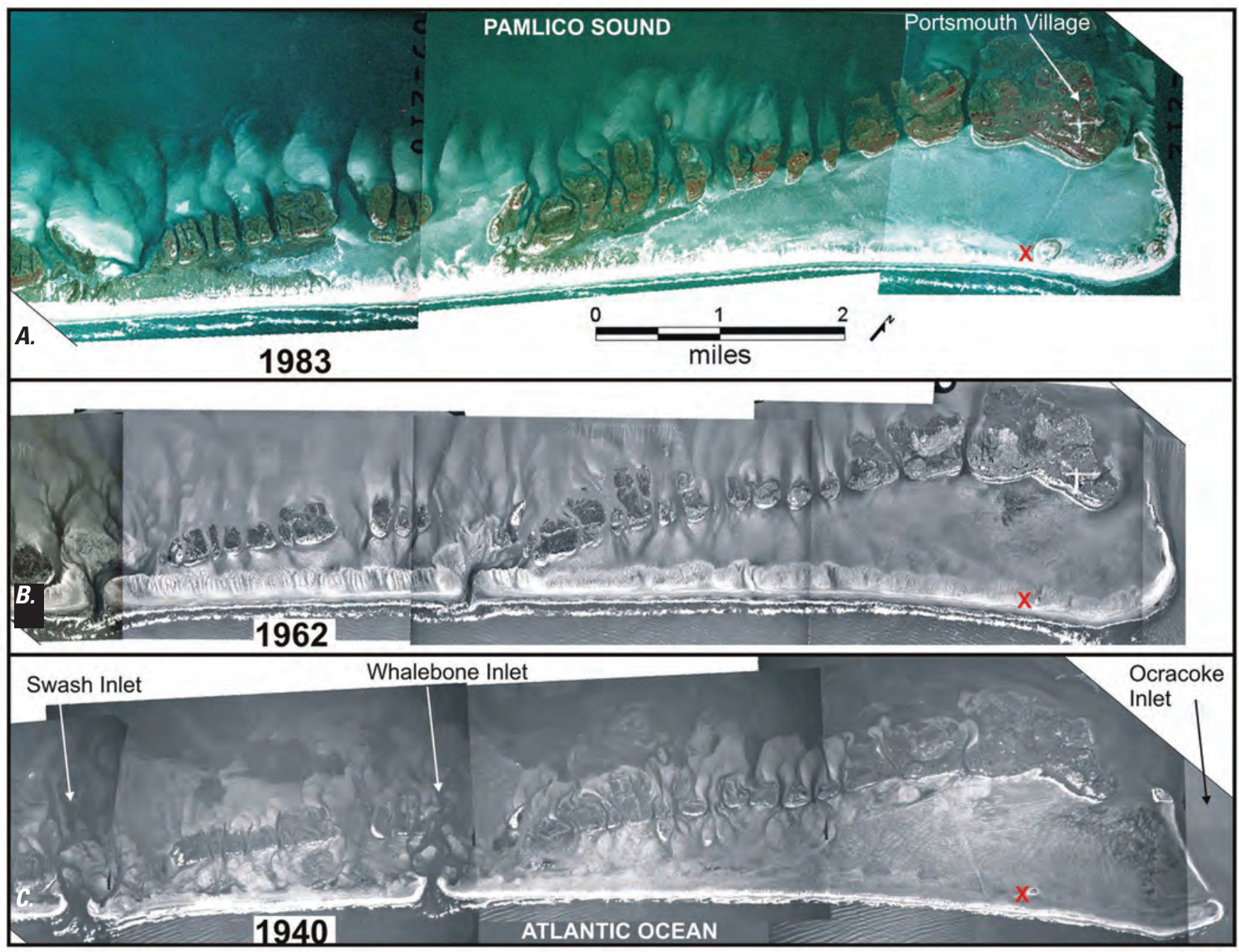

Figure 3. A three-part aerial photograph time series $(A, 1940 ; B, 1962$; and $C, 1983)$ showing the Portsmouth Village Overwash Plain with Whalebone and Swash Inlets on the southwestern part of the photographs, Core Banks, Cape Lookout National Seashore, North Carolina. The two small inlets were open and active in 1940, almost closed in 1962, and were closed in the 1983 aerial view. The $X$ on each of the photos marks an incipient foredune that grew vertically and horizontally from 1940 through 1983 as seen on the aerial photographs.

Portsmouth Village occupies the northern end of North Core Banks (fig. 1) and is adjacent to Ocracoke Inlet, the historically most stable and permanent of inlets within the northern Outer Banks. Portsmouth Village was a planned community authorized in 1753 by the Colonial Assembly and laid out with 0.5 -acre lots with streets (Stick, 1958). The town was located on the Portsmouth side of Ocracoke Inlet, rather than the Ocracoke Village side, because the main inlet channel was along the inlet's southwestern side. Portsmouth was to become the main trans-shipment point for goods coming into and going out of North Carolina. Southwest of Portsmouth, the island quickly narrows (fig. 3) and "assumes a character of isolation and sweet loneliness" (Holland, 1968).
South Core Banks is generally a very narrow ribbon of sand beach perched on the front of an extensive sequence of marsh platforms. At the southwestern end of the banks, the land widens quickly and hooks back on itself (fig. 4) "like a toggle hook on an old-time whaler's lampoon" and forms a bight of well-protected water that has been safe refuge for "storm-bedeviled" ships (Holland, 1968). Cape Lookout Bight has been a safe harbor for ships throughout historic times including the Revolutionary and Civil wars, as well as World Wars I and II. Fort Hancock was built by a Frenchman near the lighthouse during the American Revolution to protect the Cape Lookout Bight harborage. During the 1700s and 1800s, the Bight also formed harborage for New England whalers and local fishermen working the Carolina coast. 


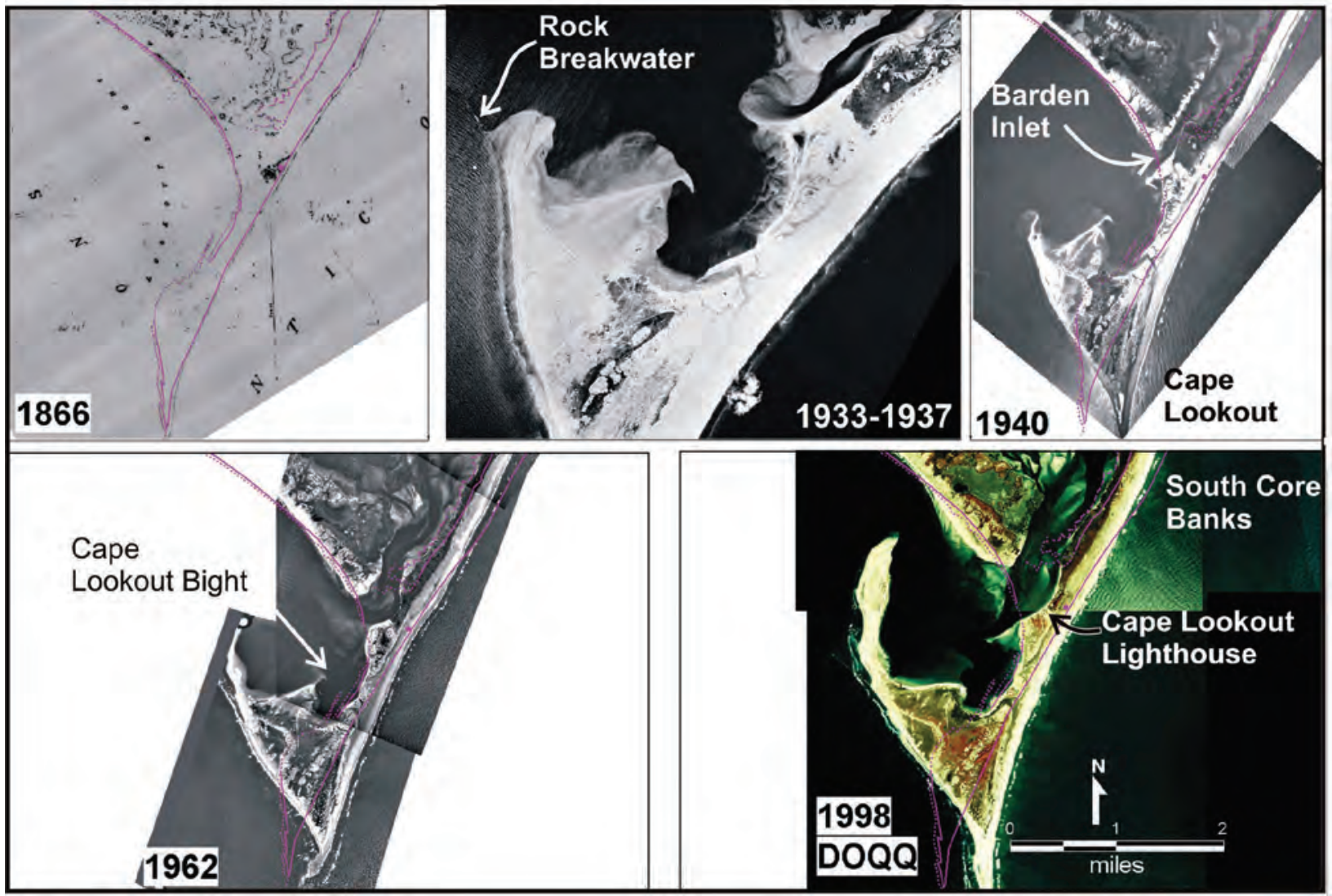

Figure 4. A five-part aerial photograph time series $(A, 1866 ; B, 1933-1937 ; C, 1940 ; D, 1962$; and $E$, 1998) showing Cape Lookout, Cape Lookout Bight, and Barden Inlet, North Carolina. $(A)$ The 1866 topographic survey shows Shackleford Banks connected to Cape Lookout with no inlet. $(B)$ This aerial photograph was taken sometime after 1933 when Barden Inlet opened in response to a hurricane as a small ephemeral inlet that was locally called "The Drain" and 1937 when the inlet was dredged for the first time. $(C, D$, and $E$ ) In 1937, the inlet was dredged producing the channel seen in the 1940 aerial photograph; it has been dredged irregularly ever since. By 1962, a distinct flood-tide delta had formed inside the inlet. Also, notice the change in geometry of the Cape after construction of a 4,800-foot long rock breakwater in 1914 in an effort to turn Cape Lookout Bight into a refuge harbor for ocean-going ships.

Cape Lookout is a prominent coastal landmark to the mariner with its infamous finger of shallow, shoreperpendicular sand shoal system (fig. 1). Cape Lookout Shoals extend south-southeast from the point of the Cape across the continental shelf for about $10 \mathrm{mi}$ with local water depths of 3 to $4 \mathrm{ft}$ and less. This feature is one of the major reasons why the North Carolina coast is known as the "Graveyard of the Atlantic." The 1590 map of coastal North Carolina by White and DeBry (Cumming, 1966), labeled the Cape Lookout as "promontorium tremendum" which translates to "horrible headland."

\section{Inlet History}

Ocean shoreline erosion patterns are influenced and controlled by the location, duration, type, physical dynamics, and history of any inlet system that either opens or closes during a given time period. Due to its location and orientation on the southeast facing side of the Cape Hatteras to Cape Lookout coastal compartment (fig. 1), Core Banks is greatly exposed to storms. There is a long history and high probability of tropical cyclones (hurricanes) moving up the east coast along the Gulf Stream and coming ashore in this coastal compartment.

The two main inlets that define the limits of Core Banks are Ocracoke Inlet on the northeast side of North Core Banks and Barden Inlet, or The Drain, on the west side of Cape Lookout (fig. 1). Ocracoke Inlet, separating Ocracoke Island from Portsmouth, was open when the Colonists arrived at Roanoke Island in 1584 and has been open ever since. It is the largest and most stable of the inlets north of Cape Lookout. Barden Inlet separates South Core Banks from Shackleford Banks (fig. 4). This inlet was originally open from about 1770 to about 1860 when it closed causing South Core and Shackleford Banks to become a single island (Payne, 1985). Barden Inlet opened again in the hurricane of 1933, which came ashore in the Cape Lookout area. It opened as a very minor inlet with minimal flow (fig. 4B) and was eventually dredged in 1937 by the USACE to produce a major channel (fig. 4C). 


\section{Ocracoke Inlet}

In 1715 Ocracoke Inlet was designated an official port of entry for Port Bath and required official harbor pilots. This was the beginning of the ascendancy of Ocracoke Inlet to the position of the most important entry port for North Carolina. Based on the USACE (1964) study, the width of Ocracoke Inlet varied from a maximum of 10,400 ft in 1856 to a minimum of 4,100 ft in 1943 and 1946. The average width was 7,300 ft, based on 17 data points from 1830 to 1962 . The area of the inlet below mean tide level averaged 103,570 square feet $\left(\mathrm{ft}^{2}\right)$, based on 10 data points from 1830 to 1962 , and ranged from $148,000 \mathrm{ft}^{2}$ to $48,000 \mathrm{ft}^{2}$. The northeastern side of Ocracoke Inlet was in a slight erosional mode from 1830 until 1865 , when it began accreting and migrating to the southwest, which it generally did from 1865 to 1961 . The southwestern side of Ocracoke Inlet has been more stable with only minor fluctuations in erosion and accretion until 1943. Between 1943 and 1961, the southwestern side generally eroded to the southwest. The channel thalweg depth, measured at a line drawn along the axis of the adjacent islands, averaged $47 \mathrm{ft}$ below mean low water (MLW) (based on 11 data points) and ranged from 30 to $62 \mathrm{ft}$ below MLW. The greatest depths generally were when the inlet was narrowest (1943-1958) and during the 1960-1962 stormy period.

Ocracoke Inlet has been maintained by dredging at various times in its past history (USACE, 1964). The USACE began an extensive dredging program for the main channel of Ocracoke Inlet in 1828 to 1835 and began construction of a jetty that was seriously damaged by a hurricane before construction was completed (Stick, 1958). The channel was finally reopened by dredging in 1895 to 1905 , when dredging was again abandoned (Stick, 1958). Another dredging program was begun in 1942 and continued irregularly through at least 1961 (USACE, 1964).

\section{Barden Inlet}

South Core Banks was initially connected to Shackleford Banks. Core Banks extended southwest beyond Shackelford Banks to form Cape Lookout. A major sand spit extended northwest to form a protected embayment called the Cape Lookout Bight (fig. 4A). "Beginning in 1912, there was an effort to turn this into a harbor of refuge for ocean-going ships in time of storms, and at the same time connecting Cape Lookout with the railroad at Beaufort" (Stick, 1958). Sand fencing was constructed on the Cape in 1913 and construction began in 1914 on a 7,050-ft long rock breakwater to protect the harbor. Only 4,800 ft was completed before the breakwater construction was terminated and the whole project was discontinued due to the start of WW I. This jetty caused a major accretion of sand that elongated the spit towards Shackleford Banks and significantly increased the areal extent of Cape Lookout Bight (figs. 4B and 4C). According to the USACE (1964), the minimum depth in Cape Lookout Bight was $30 \mathrm{ft}$.
Barden Inlet opened in the 1933 hurricane as a small and ephemeral inlet (figs. 4B and 4C) and was originally called Cape Inlet and The Drain (Stick, 1958). Barden Inlet separated Cape Lookout from Shackleford Banks. In 1937, the inlet was authorized to be dredged to a depth of $7 \mathrm{ft}$ and has been irregularly dredged ever since (figs. 4C, 4D, and 4E).

\section{The Drum Inlets}

Old Drum Inlet initially opened in about 1899 , separating North Core Banks from South Core Banks, and closed naturally in 1910. Old Drum Inlet (fig. 2A and 2B) was re-opened by a major hurricane that came ashore at Cape Lookout on September 16, 1933 and traveled just west of Core Banks into Pamlico Sound. The northeast winds, estimated to be about 125 miles per hour (mph), produced record high storm surges in the upper reaches of the Neuse and Pamlico Rivers, with low storm surge in Albemarle Sound as it moved northeastward towards the northern Outer Banks. As the storm passed, the northwest to southeast winds reversed the storm surge, which swept eastward, "overwashing Core Banks from west to east and opening Drum Inlet in the process" (Barnes, 2001).

Old Drum Inlet had to be dredged at least six times on an irregular basis from 1939 to 1952 in order to help keep it open. It finally closed naturally in January 1971 (fig. 2C). In response, the USACE artificially opened New Drum Inlet in December 1971 about $2.5 \mathrm{mi}$ to the southwest of the Old Drum Inlet site (fig. 2C). In September 1999, as the eye of Hurricane Dennis crossed Core Banks near Cape Lookout, Old Drum Inlet opened once again (fig. 2D). It is now called NewOld Drum Inlet and today is still an open and viable inlet.

In 1938, Congress authorized the USACE to dredge and maintain Drum Inlet, which opened in 1933, with a 200-ft wide and 12-ft deep channel (Stick, 1958). Based on the USACE (1964) study, the width of Old Drum Inlet varied from a maximum of $2,100 \mathrm{ft}$ in 1936 to a minimum of 300 $\mathrm{ft}$ in 1956 . The average width was $1,073 \mathrm{ft}$, based on 15 data points from 1935 to 1961 . The area of the inlet below mean tide level averaged 7,088 $\mathrm{ft}^{2}$, based on 8 data points from 1935 to 1957 , and ranged from $10,300 \mathrm{ft}^{2}$ to $5,400 \mathrm{ft}^{2}$. Drum Inlet was relatively constant in width and fixed in place from the time it opened until 1955. By 1956, the inlet had narrowed and shallowed and by 1957 had begun a rapid southwestward migration (fig. 2A and 2B). Prior to 1957, the channel thalweg depth (measured along a line drawn along the axis of the adjacent islands) averaged $14.5 \mathrm{ft}$ below MLW (based on 9 data points) and ranged from 10.5 to $22.4 \mathrm{ft}$ below MLW. By 1957, the minimum depth was listed as less than $1.5 \mathrm{ft}$. Thus, the cross-sectional area of Old Drum Inlet was more than an order of magnitude smaller than Ocracoke Inlet with about one-third the channel depth. 


\section{Ephemeral Inlets}

Numerous other smaller inlets that have opened and closed periodically during historic times in both South and North Core Banks include Cedar Inlet, Sand Island Inlet, New Inlet, Whalebone Inlet, and Swash Inlet (USACE, 1964; Fisher, 1962; Payne, 1985). On South Core Banks, Cedar Inlet was open from about 1725 to 1833 , and possibly until 1865 , and connected the Atlantic Ocean with Core Sound through Old Channel. New Inlet was located about $15.2 \mathrm{mi}$ southwest of New Drum Inlet and was open from about 1830 to about 1902. In the past, this latter inlet also was referred to as Old Drum Inlet, which is not to be confused with the Old Drum Inlet that separated North and South Core Banks prior to 1971 and reopened as New-Old Drum Inlet in 1999.

On North Core Banks, Sand Island Inlet was located $12 \mathrm{mi}$ southwest of Portsmouth Village and was open from about 1870 to at least 1961. Swash Inlet separated Portsmouth Island from Pilontary Island, and was located about $7.5 \mathrm{mi}$ southwest of Portsmouth Village. This inlet was open from 1585 through the early 18 th century. Whalebone Inlet was located about $4.7 \mathrm{mi}$ southwest of Portsmouth Village and to the southwestern side of the High Hills dunes (fig. 3). This inlet opened in 1865 and closed in the early 1900s. Swash and Whalebone Inlets reopened sometime around 1939 and were active but ephemeral inlets through 1962 (fig. 3). They were closed by 1983, and now are usually only open temporarily during major storms, when they act as overwash fans with very shallow channels that do not extend below MSL. These temporary features are referred to as overwash breaches rather than inlets, which, by definition, are required to have channels that extend well below MSL to remain open as viable inlets.

\section{North Carolina Storm History}

North Carolina has a long history with tropical storms and hurricanes. Since the Colonists first landed on Roanoke Island in 1584, storms have played a major role in both the processes of change within the natural coastal system, as well as in the lives of people living in the coastal zone. Classification of tropical cyclone intensity began in 1886 . Since then, 951 tropical cyclones were recorded in the Atlantic Ocean and Gulf of Mexico; approximately 166 or 17.5 percent of those tropical cyclones passed within $300 \mathrm{mi}$ of North Carolina (www.nc-climate.ncsu.edu/climates/hurricane.php). The geometry of North Carolina's coastline, in concert with the proximal location of the warm water Gulf Stream, makes the North Carolina coast, and particularly the three capes, favorable targets for tropical cyclones.

The actual number of hurricane strikes in North Carolina (fig. 5) is summarized by decade for the 20th century www.nc-climate.ncsu.edu/climates/hurricane.php). Based on these data, a total of 64 hurricanes of category 1 or greater made landfall from 1900 to 1999 (average $=6.4$ hurricanes/ decade). Some of these storms came ashore in South Carolina or southeastern North Carolina and traveled into the central and western part of the state with little impact on the northeastern coastal system. For the period of the present study (1960-2001), there is a strong pattern of increasing hurricane activity through time. The two decades just prior to the USACE surveys represent an active period followed immediately by a substantial decrease in storms during the 1960s and 1970s. This was followed by two decades (1980s and 1990s) of high hurricane landfall activity.

For the first 62 years of the 20th century, Core Banks experienced at least 36 hurricanes that directly affected its coastal system to some degree (USACE, 1964). Barnes (2001) described an additional 11 hurricanes that impacted Core Banks for the last 38 years of the 20th century. The 47 hurricanes do not include extra-tropical storms (such as the Ash Wednesday nor'easter) that commonly occur along the North Carolina coast during the winter season. Because of poor records for Core Banks, the USACE used data recorded at Ocracoke Village and Atlantic Beach (fig. 1) to estimate the storm surge for the hurricanes impacting Core Banks during the first 62 years of the 20th century. These surges ranged from +3 to $+10.6 \mathrm{ft}$ above MSL.

\section{Active Storm Period: 1940-1962}

The 22-year period from 1940, when the first major aerial photography was done for the entire Core Banks, through the first two USACE Core Banks surveys in 1960 and 1961, represents a time of high storm activity (fig. 5). Seventeen hurricanes impacted the North Carolina coastal system during this period, including two in 1944 and three each in 1954 and 1955 (USACE, 1964; Barnes, 2001). This stormy period culminated in Hurricane Donna in September 1960 and the Ash Wednesday storm of March 1962.

Hurricane Donna was the storm that occurred a few months after the first USACE Core Banks survey in 1960 and destroyed many of the reference markers. Hurricane Donna was a category 3 storm that moved into North Carolina over Topsail Island with a +10.6 -ft storm surge at Atlantic Beach (Barnes, 2001). The storm traveled northeast through Carteret County and Pamlico Sound, about $60 \mathrm{mi}$ west of Core Banks. The winds were up to $120 \mathrm{mph}$ along the Outer Banks; they first approached Core Banks from the south, and then slowly swung around to the southeast and finally the northeast (USACE, 1964; Barnes, 2001). Coastal communities throughout North Carolina received severe coastal erosion and extensive structural damage. Because Core Banks was on the eastern side of the storm, the Banks experienced severe flooding, overwash, and shoreline erosion. The second USACE survey took place at the end of the year (1961) following Hurricane Donna. 


\section{North Carolina Hurricane Strikes by Decade}

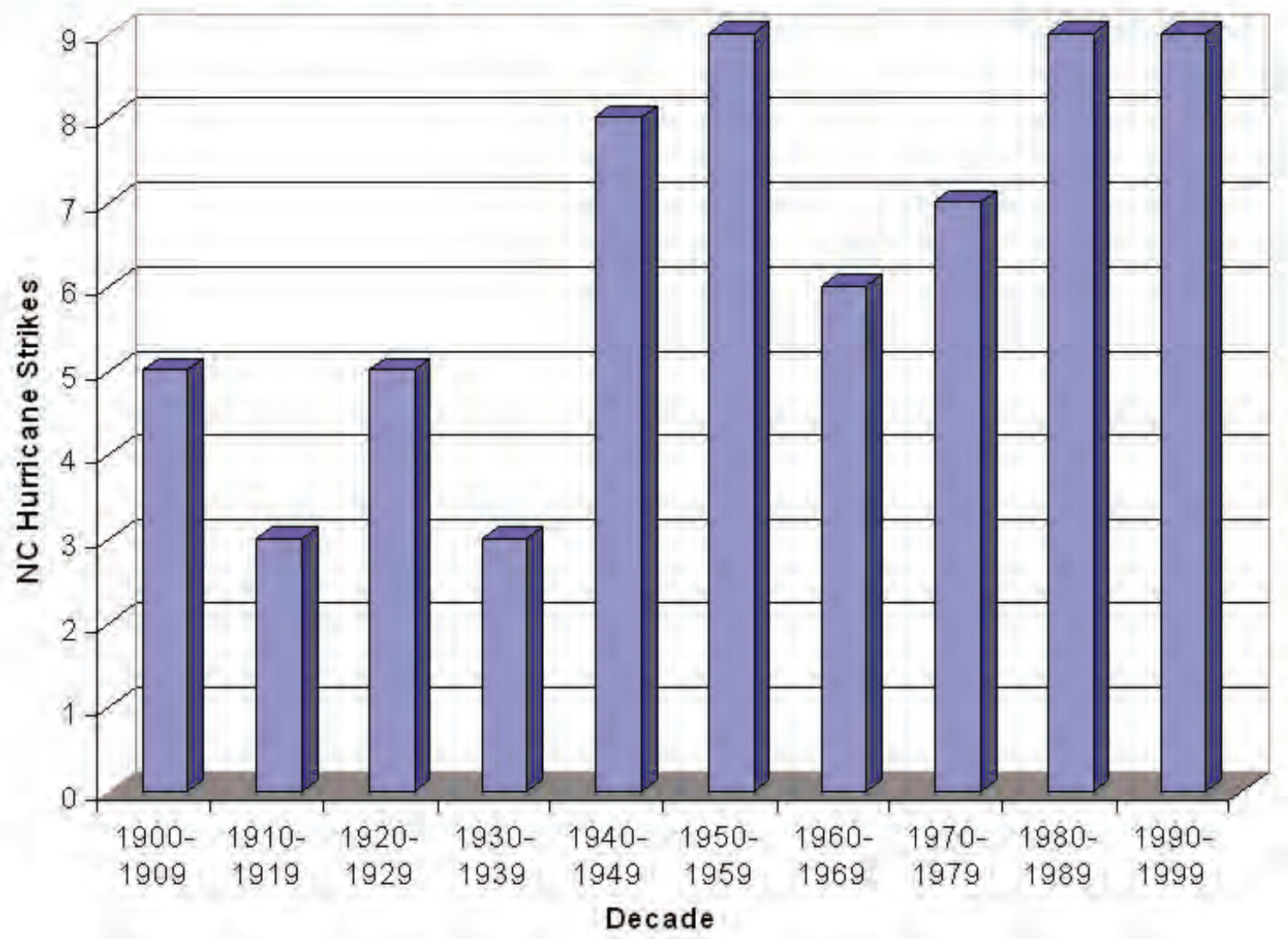

Figure 5. Total number of hurricane strikes in North Carolina by decade for the period from 1900 to 1999. (From www.nc-climate.ncsu.edu/images/climate/hurricane_by_decade_big.jpg.) 
The Ash Wednesday storm was an extra-tropical cyclone that pounded the North Carolina Outer Banks for 3 days from March 7 to 9, 1962. It lasted through a series of "near-record" spring high tides with northeast winds up to $60 \mathrm{mph}$ at Cape Hatteras (Barnes, 2001). The dominant northeast and northwest winds associated with this storm produced a +4-ft storm surge in Pamlico Sound at Ocracoke Village (USACE, 1964); however, the wind was largely offshore along Core Banks, causing a set-down of the water level on the ocean side of the barrier. As a result, the erosion was not as dominant a process as it is with most hurricanes that produce onshore winds and storm surge. The final USACE survey was conducted during the summer following the Ash Wednesday storm.

\section{Low Storm Activity Period: 1963-1970}

According to Barnes (2001) there were no major storms that directly impacted Core Banks between the USACE 1962 survey and the G\&G 1971 survey. Barnes described this as a time when the coastal waters of NC remained relatively quiet as a "mysterious period of calm." The initial G\&G 1971 survey was during the summers of 1970 and 1971 at the end of this quiescent period and prior to Hurricane Ginger.

\section{Moderate Storm Activity Period: 1971-1990}

Hurricane Ginger broke the calm as it crossed the North Carolina shoreline in the Cape Lookout area as a category 1 storm on September 30, 1971, having spent several weeks developing in the Bermuda area, east of North Carolina (Barnes, 2001). This resulted in a strong wind field with large waves up to $14 \mathrm{ft}$ high that pounded the Core Banks shoreline for many days before the storm made landfall. The storm came ashore with a surge of about $8 \mathrm{ft}$ above MSL that drove water completely across Core Banks between Cape Lookout and Portsmouth (Dolan and Godfrey, 1973). Because of the nature of this storm, there was a significant geological impact on Core Banks (Dolan and Godfrey, 1973). Hurricane Ginger broke the quiescent period and occurred while Godfrey and Godfrey (1976) were in the middle of mapping overwash fans and vegetation communities; consequently, it was a very important event captured by their cross-island profile mapping.

During the 19-year period from late 1971 to 1990 , Barnes (2001; www.nc-climate.ncsu.edu/climates/hurricane.php) recorded only four minor hurricanes that directly impacted the North Carolina coastal system.

- Hurricane Ginger: September 30-October 1, 1971 (category 1)

- Hurricane Diana: September 9-14, 1984 (category 1)

- Hurricane Gloria: September 26-27, 1985 (category 2)

- Hurricane Charley: August 17-18, 1986 (category 1)
The first two of these storms tracked across North Carolina on the westernmost side of the Pamlico Sound estuarine system. The third storm paralleled the coast and came directly over Cape Hatteras. The fourth hurricane was a weak category 1 storm that came ashore in the PortsmouthOcracoke area. A major nor'easter, the Lincoln Day Storm, occurred in February 1973.

\section{Most Active Storm Period in Recorded N.C. History: 1991-2005}

This 14-year period had 13 hurricanes that directly impacted the North Carolina coastal system, along with several major nor'easters, including the Halloween Day Storm (what is now called the "Perfect Storm") of October 1991.

- Hurricane Bob: August 19, 1991 (category 3)

- Hurricane Emily: August 31, 1993 (category 3)

- Hurricane Gordon: November 1994 (category 1)

- Hurricane Bertha: July 12-13, 1996 (category 2)

- Hurricane Fran: September 5-6, 1996 (category 3)

- Hurricane Bonnie: August 26-28, 1998 (category 3)

- Hurricane Dennis: August 30-September 5, 1999 (category 1)

- Hurricane Floyd: September 16, 1999 (category 2)

- Hurricane Irene: October 17, 1999 (category 1)

- Hurricane Isabel: September 18, 2003 (category 2)

- Hurricane Alex: August 3, 2004 (category 1)

- Hurricane Charley: August 14, 2004 (category 1)

- Hurricane Ophelia: September 14-16, 2005 (category 1)

The first nine of these hurricanes occurred prior to the ECU 2001 survey with the results factored into the long-term erosion rates. All of these storms either came directly ashore with varying impacts on Core Banks or traveled along the shoreline just east of Core Banks. The latter shore-parallel storms (i.e., Bob, Emily, Gordon, Dennis, Irene, Alex, and Ophelia) built significant sea states and storm surges. Each storm had major impacts on Core Banks shoreline erosion with small, but variable amounts of overwash as it passed offshore. In contrast, Hurricane Isabel came directly onshore at North Core Banks with a 6- to 10-ft storm surge and produced overwash fans that were deposited across the entire island in many localities. 


\section{Methods of Data Collection and Analysis}

Core Banks covers portions of nine USGS topographic quadrangles: Cape Lookout, Horsepen Pt., Harkers Is., Davis, Styron Bay, Atlantic, Wainright Is., Portsmouth, and Ocracoke. The 1998 color infrared, digital orthophoto quarter quadrangles (DOQQs) were used as base maps for the present study. The DOQQ images are in North Carolina State Plane 1983 (meter) coordinate system and MrSID format. Each DOQQ image covers the area of a quarter of a USGS 7.5minute topographic quadrangle with a spatial resolution of 1 meter. Where needed, 7.5-minute topographic maps or other map bases were used to supplement the aerial photographic coverage. All line work was digitized and manipulated in the following software programs: MapInfo Professional 6.5, ArcView GIS 3.2a, ArcGIS 8.3, and Microsoft Excel 2000. The data are stored on CD-ROMs in the Geology Department at East Carolina University, Greenville, North Carolina.

USACE (1964) established and surveyed 77 shoreperpendicular profiles $(\mathrm{P})$ on North and South Core Banks numbered P1 (at Cape Lookout) through P77 (at Ocracoke Inlet) as indicated on figure 6 . The profiles were spaced at 3,000-ft intervals, except for profiles P1 and P77, which were about 2,400 ft from P2 and the Ocracoke Inlet shoreline, respectively. The odd-numbered profiles on North Core Banks and the even-numbered profiles on South Core Banks were short and only extended across the seaward portion of the barrier islands (fig. 6). The opposite-numbered profiles were long and extended into the estuary to -10-ft water depths and seaward into the ocean to depths of $-30 \mathrm{ft}$ below MSL (fig. 6).

Each profile has three or more reference markers (RM) located $100 \mathrm{ft}$ apart along the shore-perpendicular profile line (fig. 7). RM-0 is closest to the ocean and constitutes the baseline monument for all 77 profiles. Each reference marker consists of a 1.5-inch (in.) steel pipe with a threaded cap on top (fig. 8A) with the profile and reference marker numbers stamped in the top. Each reference marker was set at least $4 \mathrm{ft}$ in the sand with about 8 in. of pipe rising above a 1 - to $2-\mathrm{ft}$ diameter concrete collar (fig. 8B). The top of the concrete also contains the profile and reference marker numbers and represents the sediment surface at the time of installation in 1960-62 (fig. 8B). A 4 X 4-in. by 7-ft wooden marker post was initially installed $3 \mathrm{ft}$ into the ground adjacent to each RM-0 with a 2 X 4-in. cross member below the sediment surface to resist withdrawal. Today, many of the pipes are deeply buried in sand, highly rusted (fig. 8B), or severely eroded (fig. 8C). Most of the original wooden guard posts are gone; Cape Lookout personnel have placed new wooden posts adjacent to many of the relocated reference markers (fig. 8C).

USACE survey data on Core Banks for each profile and associated reference markers included elevation above MSL (based on the 1929 datum) and distance to the shoreline of the 1929 datum. Bathymetric profiles run into the estuary and seaward into the ocean also are based on the 1929 datum. The initial USACE (1964) survey took place in June 1960. Many reference markers from the first survey were destroyed by Hurricane Donna on September 12, 1960. The destroyed reference markers were replaced and resurveyed in September to December 1961, only to be destroyed by the Ash Wednesday extra-tropical cyclone in March 1962. The USACE re-established and resurveyed the reference markers for the third time during June to July 1962. At that time additional reference markers were installed landward of the surviving reference markers along the existing 76 profiles. Profile P1 was found to be unusable so a new profile, A1, was set $400 \mathrm{ft}$ north of P1.

A schematic diagram that shows the methods used by the USACE (1964) to determine the shoreline changes in their 1960, 1961, and 1962 surveys is shown in figure 7. The USACE datum was the 1929 MSL. In order to adequately determine the shoreline change through time, it was necessary for the G\&G 1971 (Godfrey and Godfrey, 1976) and ECU 2001 (this report) shoreline surveys to use the 1929 MSL datum as demonstrated in figure 7. However, because sea level has been steadily rising in coastal North Carolina since 1929 (Riggs and Ames, 2003), the 1929 shoreline is now some distance seaward of the modern shoreline. The control is the known elevation of the reference markers surveyed by the USACE. Consequently, the procedure used by both the 1971 and 2001 surveys involved level lines shot from a reference marker onto a stadia rod that was moved seaward down the beach face until the elevation on the stadia rod was equal to the elevation of the reference marker. The horizontal distance between the reference marker and the stadia rod represents the 1971 and 2001 shorelines, respectively.

As an integral part of the 1961 survey, the USACE ran a series of bathymetric profiles on both the Atlantic Ocean and Core Sound sides of the barrier islands (USACE, 1964). The shoreface bathymetric survey data for Core Banks is summarized in appendix 2. The USACE 1961 bathymetric survey data represent the horizontal distance obtained along alternate profiles (fig. 6) and measured from the MSL shoreline, based on the 1929 datum, out to the 6-, 12-, 18-, 24-, and 30-ft submarine contours, respectively.

The general procedure used in the ECU 2001 survey by Mr. Robert White with substantial help from Dr. Michael Rikard and other CALO personnel, was as follows. 
A.

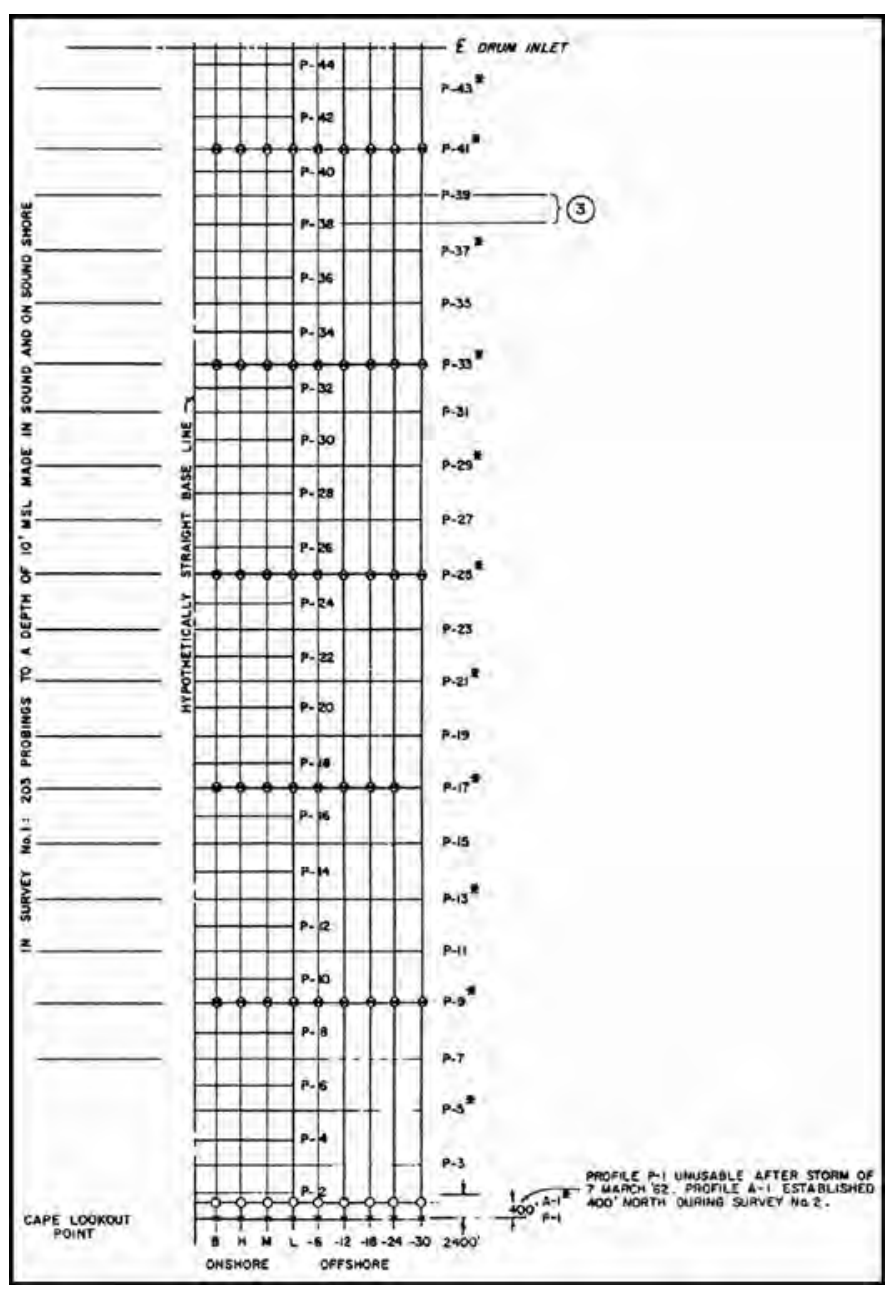

B.

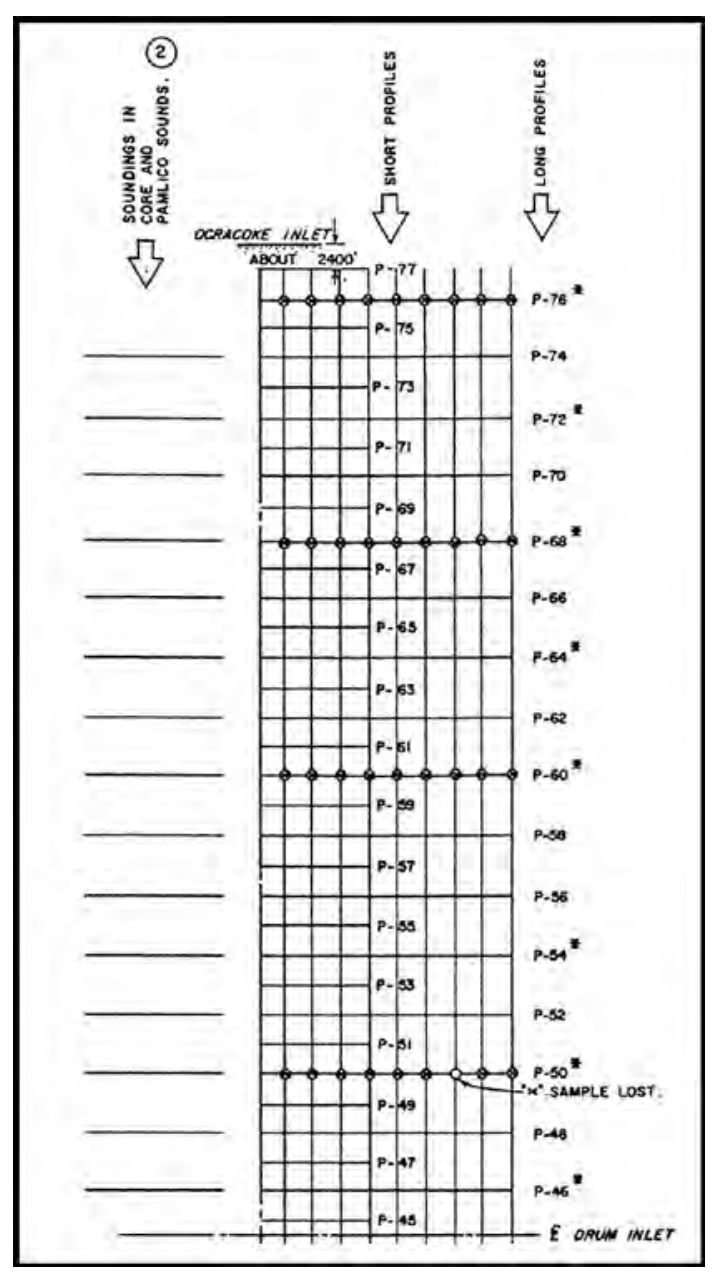

Figure 6. The 77 profiles and associated topographic and bathymetric surveys done from 1960 to 1962 by the U.S. Army Corps of Engineers (USACE) on North Core Banks $(A)$, and South Core Banks $(B)$, Cape Lookout National Seashore, North Carolina. (From USACE,1964.) 


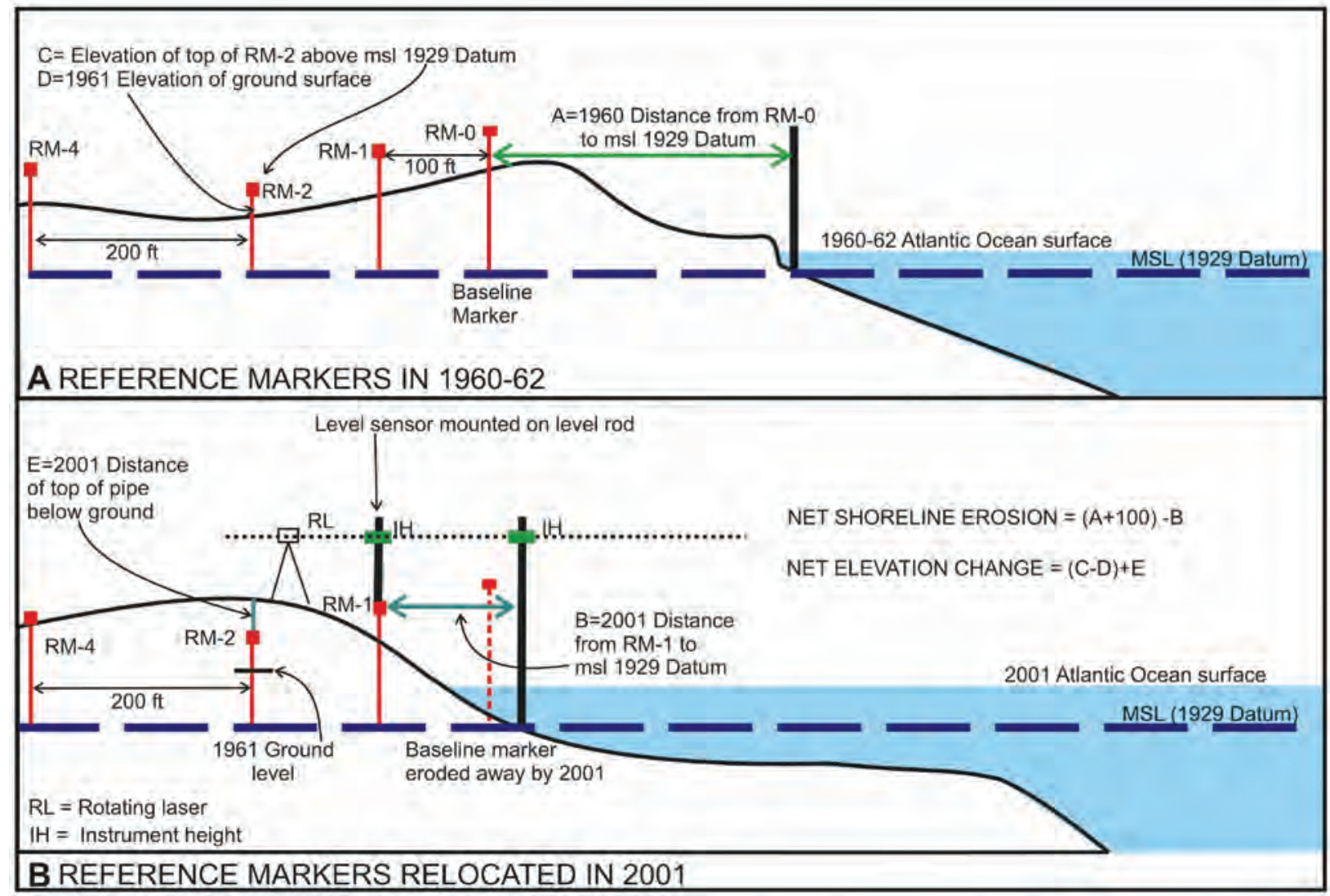

Figure 7. (A) One profile line with reference markers (RMs) developed for the 1960 to 1962 surveys of North and South Core Banks, Cape Lookout National Seashore, North Carolina. This panel also shows the method used by the USACE (1964) survey to measure the horizontal distance to the shoreline and vertical elevation change. $(B)$ The same profile surveyed in 2001 and the method for determining net change in shoreline location and elevation. 

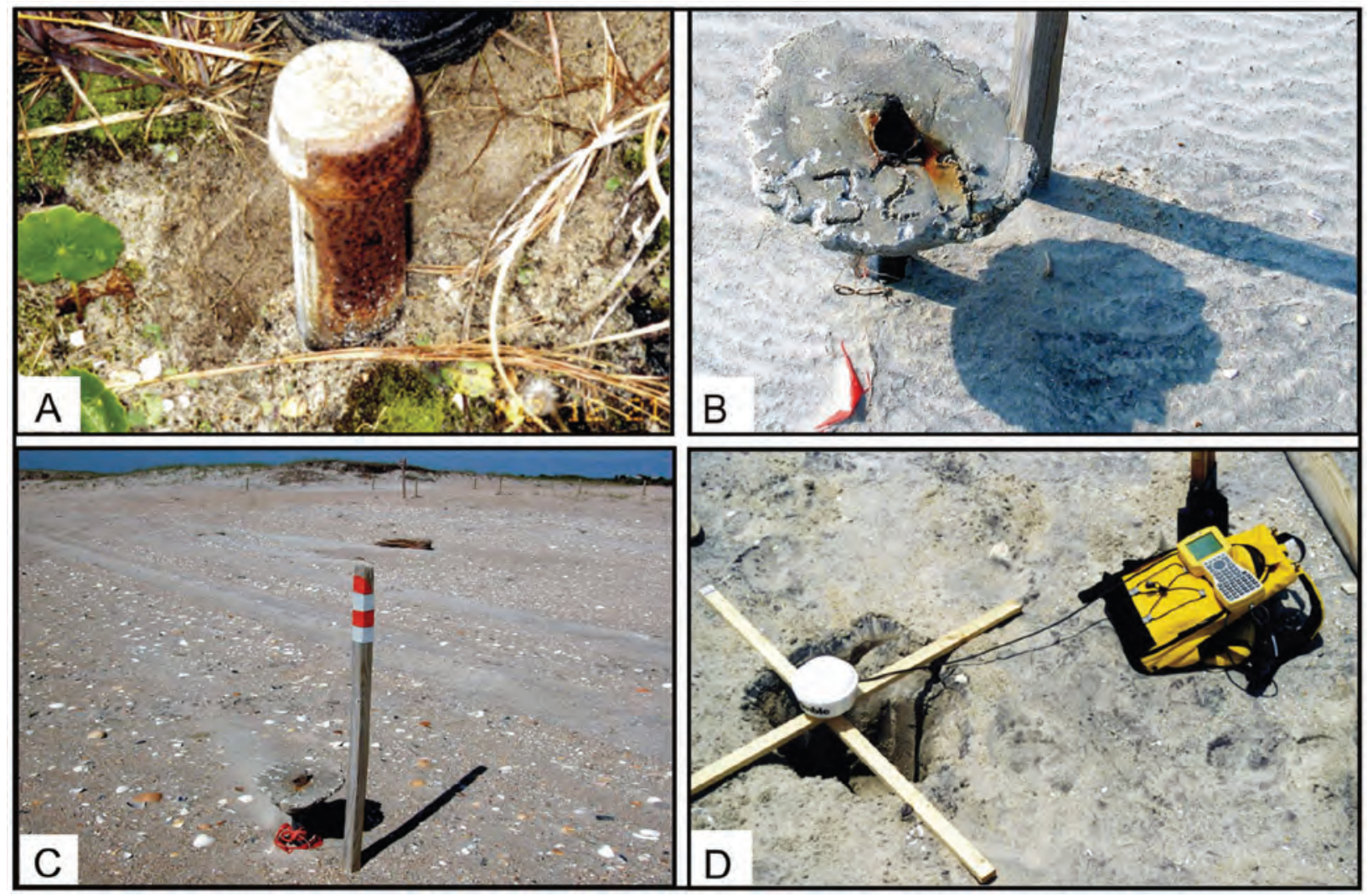

Figure 8. Relocated U.S. Army Corps of Engineers 1960-1962 reference markers (RM) on Core Banks, Cape Lookout National Seashore, North Carolina. (A) Photograph taken in 2001 of the top of a reference marker that was not totally buried. (B) Photograph shows RM 32-1, which has been eroded, exposing the cement collar that was poured with the top at ground surface. Notice that the pipe above the concrete has totally rusted away. $(C)$ Photograph taken in March 2004 near Drum Inlet on South Core Banks. Hurricane Isabel (9-18-2003) eroded the shoreline and exposed this reference marker on the active beach. $(D)$ Photograph shows the ECU 2001 method for surveying the latitude and longitude of each relocated reference marker using a Trimble Global Positioning System unit.

1. The search to locate and recover as many reference markers as possible along the 77 profiles began from a known USACE profile with one or more exposed reference markers.

2. Using the known 100-ft distance between reference markers and the known 3,000-ft distance between profiles, the theoretical locations of adjacent reference markers and profiles were determined using a Trimble ProXRS Global Positioning System (GPS) unit.

3. If no reference markers were exposed, a ferrous iron "Ferro-Trak" metal detector was used to locate the existing buried reference markers along that profile. If it was obvious that the reference marker had been lost to erosion, the search shifted to the next landward reference marker along that profile.

4. Once a buried reference marker was located and uncovered, the horizontal location was determined by collecting 180 to 300 data points using the GPS unit with the antenna located on top of the reference marker, as indicated in figure $8 \mathrm{D}$. The relevant data were transferred to a personal computer and differentially corrected by post-processing with software version 2.80 of GPS Pathfinder Office. The horizontal accuracy is better than $+/-1$ meter. The location data are presented in appendix 5 .

5. Work proceeded along the islands until all possible reference markers were located and their horizontal location mapped with the GPS unit. The locations were plotted along the 1998 DOQQ mosaic.

6. One or more reference markers were recovered from 57 of the total 77 profiles (fig. 9). No locatable reference markers were found for 20 profiles due to one or more of the following reasons: (a) the reference markers were eroded by the sea either as the shoreline receded or by inlet dynamics, 
(b) the reference markers were rusted away or buried too deeply for the metal detector to pick up, or (c) the reference markers were destroyed by human activity.

7. The amount of elevation change was measured from the top of the metal pipe to the present sediment surface (appendix 6) and compared to the original elevation data as recorded by the USACE (appendix 1) to determine the amount of accretion if the reference marker was buried or deflation if the reference marker was exposed.

8. At each relocated profile, the recovered reference marker closest to the ocean was used to gather the 2001 shoreline change data. The procedure for measuring the distance from a surviving reference marker to the 2001 shoreline based on the 1929 MSL datum is shown in figure 7. A TOPCON Marksman RL-50A rotating laser was used for the survey with a Level Sensor LS-50B mounted to a wooden Philadelphia Level Rod.

9. The rotating laser was set up near the reference marker, the level rod was placed on the reference marker (of known elevation based on the 1929 datum), and the level sensor mounted on the rod was placed in line with the laser beam. The elevation of the level sensor on the level rod was recorded as the "instrument height." With the level sensor still in place on the level rod, the level rod was extended and moved seaward along a straight line perpendicular to the shore until the laser beam hit the level sensor at the instrument height. The horizontal distance from the reference marker to that position was the distance to the 2001 shoreline based on the 1929 MSL datum and is reported in appendix 6.

10. The difference between the 2001 distance from the reference marker to the 1929 MSL and the distance as previously determined by the USACE in the 1960 survey, is the net change in shoreline that has occurred over the 41-year time period. These data are listed in appendix 6 . The net shoreline change that has occurred during the other time periods is the difference between the ECU 2001 survey distance and the distance obtained by the USACE 1961, 1962, and the G\&G 1971 surveys, respectively.

11. The ECU survey data were tabulated, calculated for the different time periods (appendix 6), and statistically compared with the data sets of USACE 1960-1961, 19611962, 1960-1962 (appendixes 1 and 2); G\&G 1962-1971 (appendixes 3 and 4); and NCDCM 1946-1992, and 1946-1998 (appendix 7). Simple statistics (averages, etc.) and correlation coefficients were determined using statistical functions in Microsoft Excel 2000.

12. The net shoreline change and the average rate of change for each profile along Core Banks were graphed and plotted along the 1998 DOQQ mosaic for Core Banks to facilitate correlation of shoreline change with barrier island processes.
13. The net elevation change was calculated for the different sets of the RM- 0 , RM-1, and RM-2 relocated reference markers.

14. The net shoreline change data were plotted against the USACE 1961 shoreface slope data (appendix 2) to determine the relationship of erosional processes to shoreface geometry.

The shoreline recession data used by NCDCM, as well as many other shoreline recession studies, are based on a different method from that used by USACE. NCDCM data (Benton and others, 1993; 1997) are based on differences between two end-point sets of georeferenced aerial photographs. The $\mathrm{X}$ located on the schematic drawings in figure 10 is the location of a theoretical wet-dry line and demonstrates the theoretical difference in results produced by the NCDCM method as compared to the USACE method. Thus, shoreline erosion data obtained by these two different methods should not be exactly the same; however, the two methods should approximate each other and show similar patterns of shoreline change through time.

The NCDCM developed two long-term shoreline erosion data sets for the entire North Carolina ocean shoreline based on the "end-point" method of aerial photographic analysis (Benton and others, 1993; 1997). This method uses sets of georeferenced aerial photographs and measures the location of the wet-dry line on the beach between the earliest and the most recent aerial photographs. The distance between the two wetdry lines is measured along previously established transects that are perpendicular to the shoreline. The total distance of change is then divided by the number of years between the two end points to obtain the average annual rate of shoreline change.

The NCDCM procedures for data presentation subdivide the shoreline into segments with similar erosion rates. Each segment is at least 0.25 -mi long and consists of grouped consecutive shoreline change rates that differ by $1 \mathrm{ft} / \mathrm{yr}$ or less. The erosion rate, or erosion factor, appears on each segment on the aerial photographs in the report. Segments that have accreted or eroded less than $-2 \mathrm{ft} / \mathrm{yr}$ are automatically assigned an erosion factor of $-2 \mathrm{ft} / \mathrm{yr}$ for regulatory purposes. The Core Banks portion of the two long-term shoreline erosion data sets, NCDCM 1940-1992 and 1946-1998, are summarized in appendix 7. The NCDCM long-term data were used primarily as a cross check for the ECU 1960-2001 long-term data. Although they represent somewhat different time periods and different survey methods, the data produced similar results. 


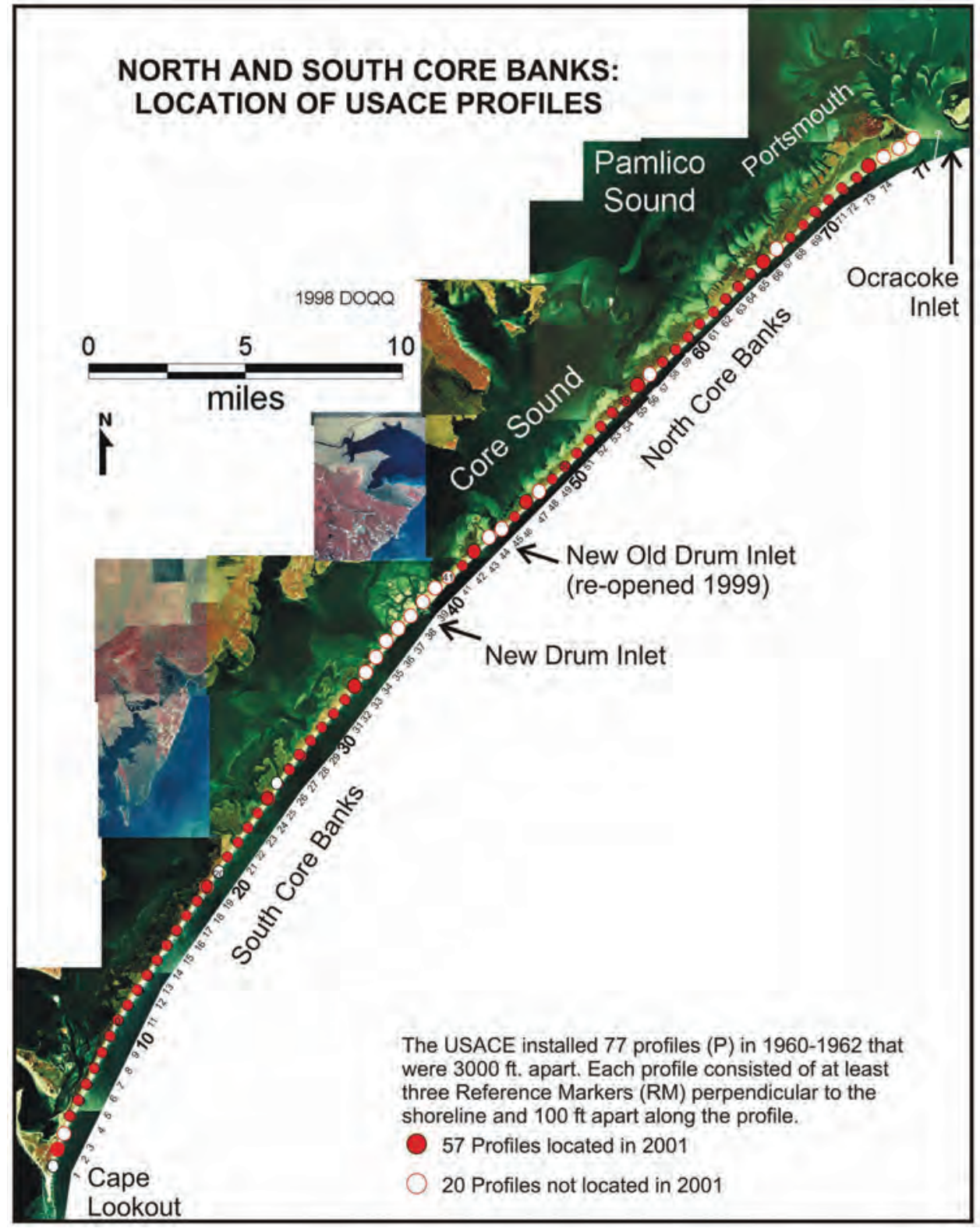

Figure 9. The 57 profiles located by the 2001 East Carolina University survey of the original 77 profiles established by the U.S. Army Corps of Engineers on North and South Core Banks, Cape Lookout National Seashore, North Carolina. Data are listed in appendix 5. Data are plotted along the $1998 \mathrm{DO00}$ mosaic for Core Banks. The red circles show the 57 profiles with one or more reference markers that were relocated in the 2001 ECU survey. No reference markers were located along the 20 profiles marked with white circles. 

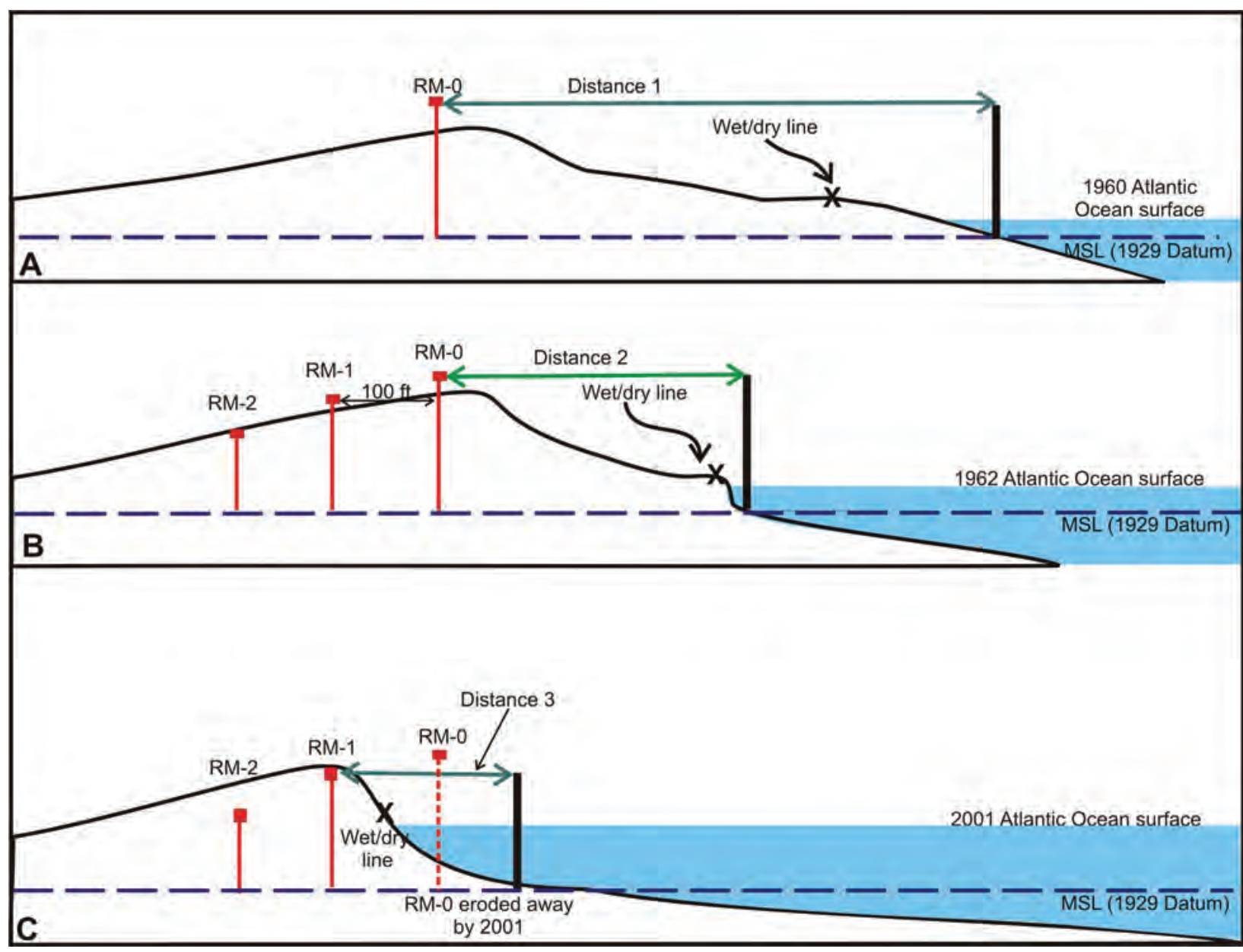

Figure 10. The method used by the U.S. Army Corps of Engineers, Godfrey and Godfrey, and East Carolina University to determine shoreline changes in their $1960(A), 1961,1962(B), 1971$, and $2001(C)$ shoreline surveys, Core Banks, Cape Lookout National Seashore, North Carolina. All these surveys used a mean sea level based on the 1929 datum. The X on the diagrams represents the wet-dry line that is used in many aerial photograph analyses of shoreline erosion, including the method used by the North Carolina Division of Coastal Management. Notice the potentially different results obtained by using the two different methods.

\section{Effect of Storms on Barrier Island Dynamics}

Coastal storms have a substantial effect on the geomorphology of barrier islands and inlets on North Carolina's Core Banks. Changes in shoreline geometry and island elevation were determined by comparing five survey data sets of 77 shore-perpendicular profiles and associated reference markers, in concert with the analysis of georeferenced aerial photographs. The results document the historical pattern of shoreline and elevation changes through time and demonstrate the importance of storms in the evolution of barrier islands; these processes have significant implications for the coastal management of barrier islands.

\section{Shoreline and Elevation Changes on Core Banks}

\section{U.S. Army Corps of Engineers Data Sets}

Data from the three surveys by the USACE are presented in appendix 1. Columns E, F, and $\mathrm{G}$ record the distances from the baseline reference marker (RM-0) to mean sea level (MSL 1929 datum) along each profile for the 1960, 1961, and 1962 surveys, respectively. Because the reference markers are 100 $\mathrm{ft}$ apart, adding 100 to the distance measured for RM-0 yields the distance of RM-1 to the shoreline (MSL 1929 datum).

Data from the 1961 survey also record the elevation at the top of the reference markers and at ground elevation (appendix 1, columns $\mathrm{C}$ and $\mathrm{D}$ ). 
A histogram plot (fig. 11) shows the net shoreline change data for the 77 profiles on Core Banks for the USACE 19601961 survey (blue) and the USACE 1961-1962 survey (red). The initial survey was carried out in June 1960 with many of the reference markers being destroyed by Hurricane Donna on September 12, 1960. The reference markers were replaced and resurveyed in September to December 1961 only to be partially destroyed by the Ash Wednesday nor'easter in March 1962. Thus, a third survey was undertaken in June to July 1962. This plot shows the patterns of shoreline erosion and accretion associated with three surveys and two major storms. Comparison of these data sets demonstrates that profiles experiencing erosion in one storm, generally exhibit accretion during a second storm and vice versa.

These data sets captured the impact of a major, but different kind of storm event (fig. 12). The 1960-1961 data set captured the severe erosional impact of Hurricane Donna, a category 3 cyclonic storm that moved through North Carolina about 60 mi west of Core Banks. The subsequent September to December 1961 resurvey by the USACE (1964) took place more than 1 year after Hurricane Donna. In spite of the long time period between the storm and resurvey, the shoreline change data along Core Banks ranged from a maximum erosion rate of $-164 \mathrm{ft} / \mathrm{yr}$ to a maximum accretion rate of $+112 \mathrm{ft} / \mathrm{yr}$ with an overall average annual erosion rate of -40 ft/yr for all of Core Banks (table 1).

The 1961-1962 data set (fig. 13) captured the impact of the Ash Wednesday extra-tropical cyclone or nor'easter. The subsequent June-July 1962 resurvey by the USACE (1964) represents only a 3- to 4-month post-storm period. The shoreline response data ranged from a maximum erosion rate of $-226 \mathrm{ft} / \mathrm{yr}$ to a maximum accretion rate of $+153 \mathrm{ft} / \mathrm{yr}$ with an overall average annual erosion rate of $-26 \mathrm{ft} / \mathrm{yr}$ for all of Core Banks (table 1). Larger maximum erosion and maximum accretion numbers are shown on figure 12; however, these large numbers are related to the opening and/or migration of inlet channels and spits and have been removed from the calculations concerning shoreline recession (tables 1 and 5).

The maximum erosion and accretion and average annual rate of erosion and accretion resulting from the two storms and determined by the three USACE surveys for Core Banks are summarized in table 1 . The overall average annual erosion rate for this 3-year period (1960-1962) was -36 ft/yr with a net maximum erosion of $-97 \mathrm{ft} / \mathrm{yr}$ and net maximum accretion of $+45 \mathrm{ft} / \mathrm{yr}$. Table 1 also summarizes the net impact of both these storm-dominated survey sets combined as a net shoreline change for the USACE 1960-1962 data set. The net average annual erosion rate for all of Core Banks is $-36 \mathrm{ft} / \mathrm{yr}$. This demonstrates a general smoothing out of the maximum erosion and accretion rate data to smaller numbers of $-97 \mathrm{ft} / \mathrm{yr}$ and +45 ft/yr, respectively.

Because there are no weather instruments on Core Banks or in the surrounding areas and no people live on these islands, absolute weather conditions during these two storms cannot be determined. However, these two types of storms produce very different coastal conditions, in terms of storm surge, wave setup, wind direction, wind velocity, and duration, and would probably cause the different responses displayed in the two data sets. For example, Hurricane Donna was a fast (1 day), northward-moving category 3 hurricane that produced direct onshore winds along Core Banks with possibly a $+10-\mathrm{ft}$ storm surge. In comparison, the Ash Wednesday nor'easter was of long duration (3 days) through numerous high-tide cycles, with lower wind velocities (up to $60 \mathrm{mph}$ ) that were dominantly shore parallel and possible storm surges up to $+4 \mathrm{ft}$ above MSL. These storm differences probably are the cause for the inverse relationship of these two data sets.

The initial ground elevation data for all 264 reference markers installed and surveyed by the USACE in 1961 are listed in appendix 1 (column D). The USACE installed 77 reference markers at RM-0, RM-1, and RM-2, respectively along each of the 77 profiles. In addition they installed 33 reference markers that were labeled RM-4, RM-6, and RM-8 in a few wide portions of Core Banks (see appendix 1, column B). The ground elevation data for the USACE 1961 survey are summarized in table 2.

During the USACE 1961 survey, the horizontal distances and water depths for all alternate profiles were measured from the shoreline seaward to the 6-, 12-, 18-, 24-, and 30-ft depth contours. Water depth was based on the 1929 MSL datum. The horizontal distance data from RM-0 on alternate profiles to the sequential bathymetric contours out to the $30-\mathrm{ft}$ water depth contour are listed in appendix 2. The 1961 data are plotted as histograms in figure 13 along the 1998 DOQQ mosaic to allow comparison of shoreface slope with the shoreline erosion processes on Core Banks.

The horizontal distance seaward from the shoreline of Core Banks to the 30-ft bathymetric contour surveyed in 1961 by the USACE is plotted on figure 14. The lowest slope occurs along profiles P1 to P15 adjacent to Cape Lookout and along P74 to P77 adjacent to Ocracoke Inlet. Between these two end points, the slope increases to its steepest point between P19 and P31, which is just southwest of New Drum Inlet. P31 is approximately where the major bend is in South Core Banks (see oblique aerial photograph; fig. 24A). This is also the area where the 6- and 12-ft bathymetric contours have steep slopes. 


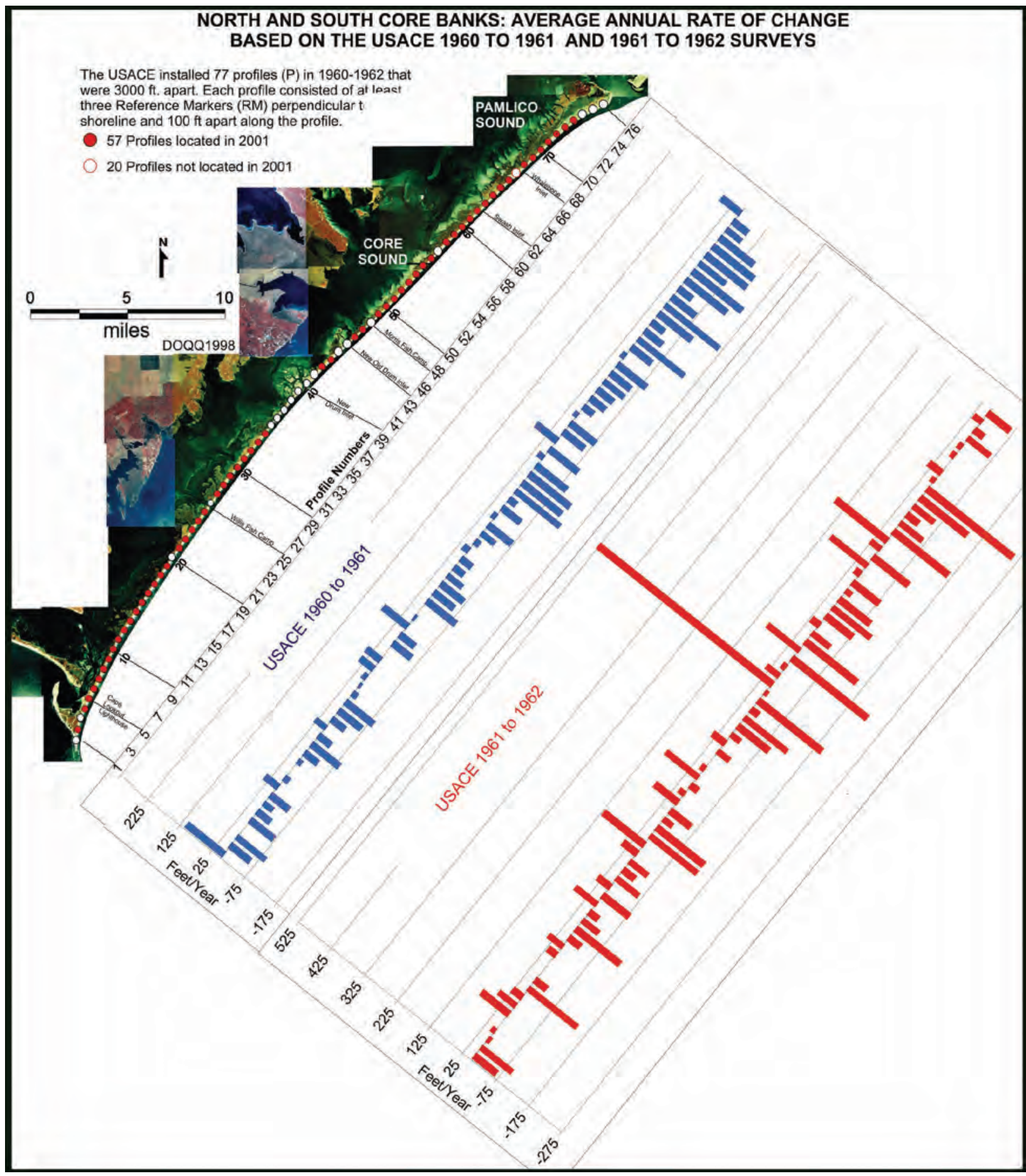

Figure 11. Net shoreline change data for 77 profiles between the U.S. Army Corps of Engineers between the 1960 and 1961 surveys (blue) and the 1961 and 1962 surveys (red), Core Banks, Cape Lookout National Seashore, North Carolina. Data are listed in appendix 1. These plots show the patterns of shoreline erosion and accretion associated with three surveys and two major storms. The initial survey was conducted in June 1960 with many of the reference markers destroyed by Hurricane Donna on September 12, 1960. The reference markers were replaced and resurveyed in September to December 1961 only to be partially destroyed by the Ash Wednesday nor'easter in March 1962. A third survey was conducted in June to July 1962. The data are plotted along the 1998 D000 mosaic for Core Banks. 


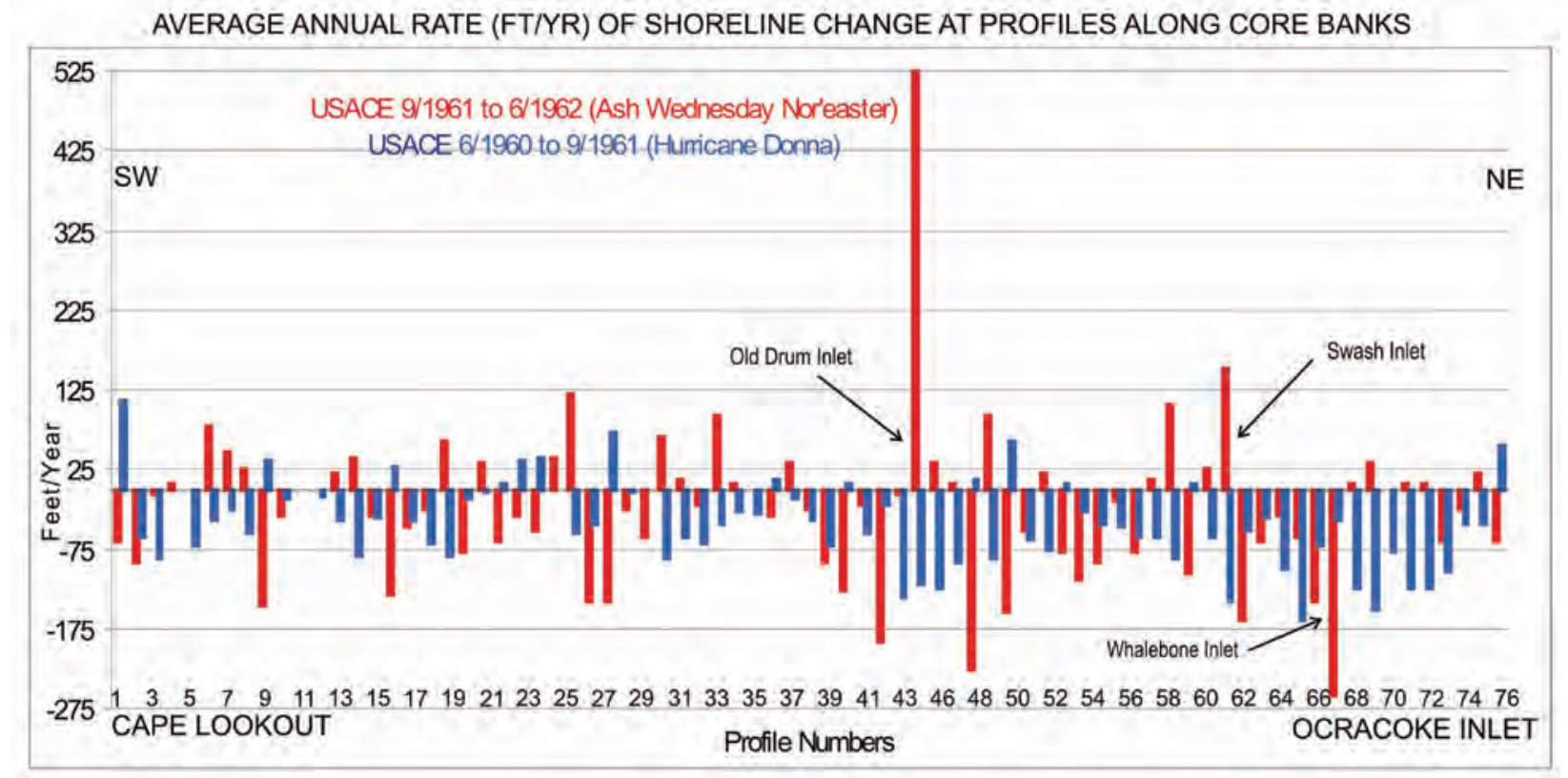

Figure 12. Average annual rate of shoreline change for the 77 profiles between the U.S. Army Corps of Engineers 1960 and 1961 surveys (blue) and the 1961 and 1962 surveys (red), Core Banks, Cape Lookout National Seashore, North Carolina. Data are listed in appendix 2. This plot shows the generally inverse pattern of shoreline erosion and accretion resulting from the two different types of storms.

Table 1. Maximum and average annual rates of shoreline erosion and accretion for each of the shoreline survey data sets for North and South Core Banks combined, Cape Lookout National Seashore, North Carolina.

[The three U.S. Army Corps of Engineers (USACE) data sets represent short-term surveys that bracketed two major storms. The Godfrey and Godfrey $(G \& G)$ data set is the short-term, non-storm period that followed the USACE surveys. The East Carolina University (ECU) and North Carolina Division of Coastal Management (NCDCM) data sets represent long-term shoreline erosion rates]

\begin{tabular}{|c|c|c|c|}
\hline Data sets & $\begin{array}{c}\text { Average erosion } \\
\text { (ft/yr) }\end{array}$ & $\begin{array}{c}\text { Maximum erosion } \\
(\mathrm{ft} / \mathrm{yr})\end{array}$ & $\begin{array}{c}\text { Maximum accretion } \\
\text { (ft/yr) }\end{array}$ \\
\hline USACE $1960-61^{1}$ & -40 & -164 & +112 \\
\hline USACE $1961-62^{1}$ & -26 & -226 & +153 \\
\hline USACE 1960-621 & -36 & -97 & +45 \\
\hline G\&G 1962-71 & +12 & -11 & +55 \\
\hline ECU 1960-2001 & -5 & -19 & 0 \\
\hline NCDCM 1946-982 & -5 & -30 & \\
\hline
\end{tabular}

\footnotetext{
${ }^{1}$ The extremely high erosion and accretion numbers associated with the opening, migration, and closing of inlets on North Core Banks resulting
} from the two storms have been eliminated from this analysis (i.e., profiles P44, P45, P62, P66, P67, and P68).

${ }^{2} \mathrm{NCDCM}$ data does not recognize accretion. 


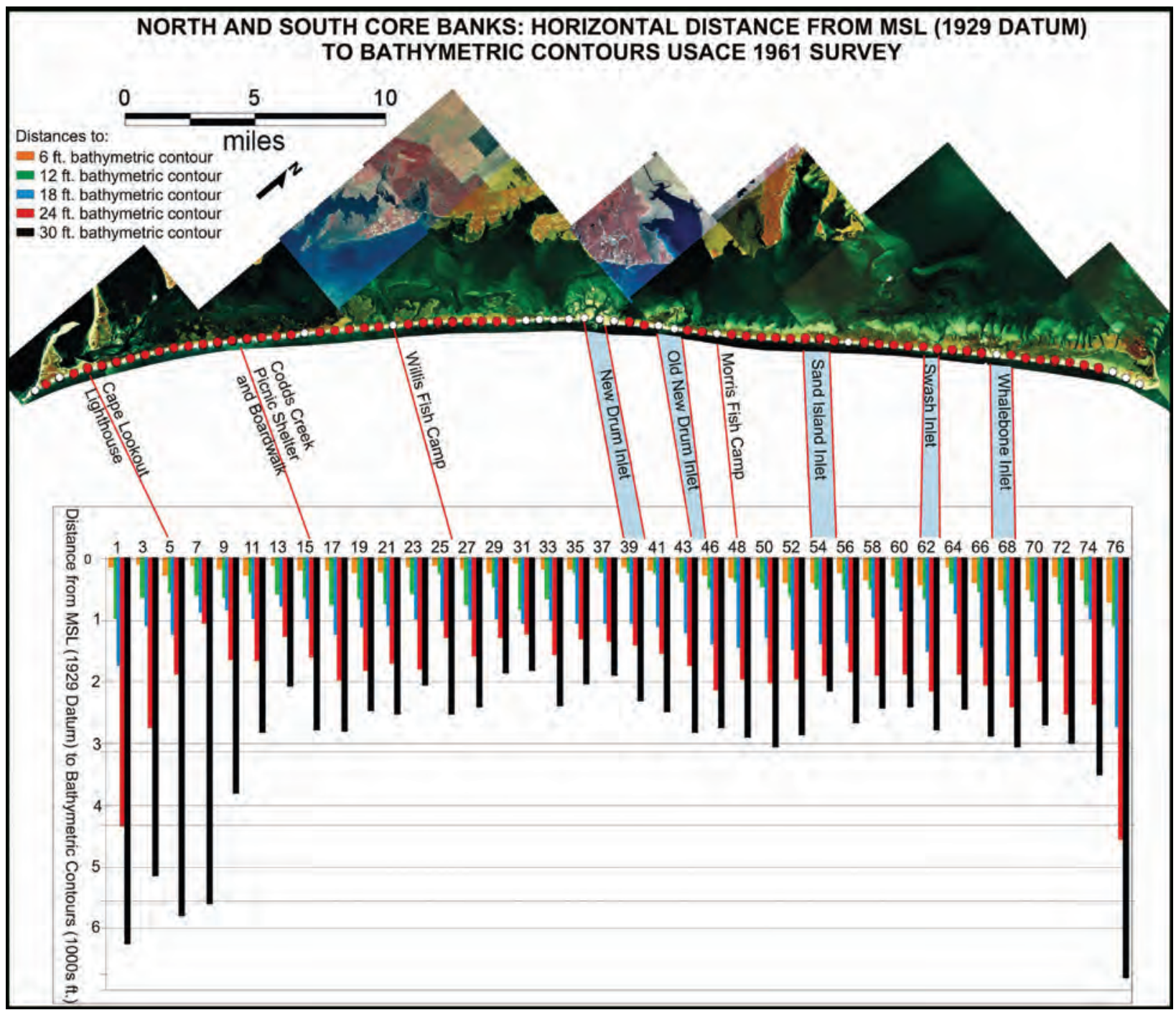

Figure 13. Horizontal distance from the shoreline to the 6-, 12-, 18-, 24-, and 30-foot depth contours for all alternate profiles from the U.S. Army Corps of Engineers 1961 survey, Core Banks, Cape Lookout National Seashore, North Carolina. Data are listed in appendix 2. The data are plotted along the $1998 \mathrm{D000}$ mosaic to relate the shoreface slope to the general shoreline features and associated erosion rates on Core Banks. Water depth is based on the 1929 MSL datum.

Table 2. Summary of the elevation data for 231 reference markers on 77 profiles from the 1961 U.S. Army Corps of Engineers survey for Core Banks, Cape Lookout National Seashore, North Carolina.

[USACE, U.S. Army Corps of Engineers; see appendix 1 for data. All elevations are in relation to mean sea level (1929 datum)]

\begin{tabular}{lcccc}
\hline \multicolumn{1}{c}{ Reference markers } & RM-0s & RM-1s & RM-2s & $\begin{array}{c}\text { All reference } \\
\text { markers }\end{array}$ \\
\hline USACE 1961 Total number of reference markers & 77 & 77 & 77 & 264 \\
\hline USACE 1961 Average ground elevation (in feet) & +5.8 & +5.2 & +4.8 & +5.0 \\
USACE 1961 Maximum ground elevation (in feet) & +9.2 & +8.8 & +11.6 & +11.6 \\
USACE 1961 Minimum ground elevation (in feet) & +2.3 & +2.1 & +2.1 & -1.3 \\
\hline
\end{tabular}

'Includes all reference markers from RM-0 through RM-2 plus all others through RM-8 that were established by the USACE in 1961. 


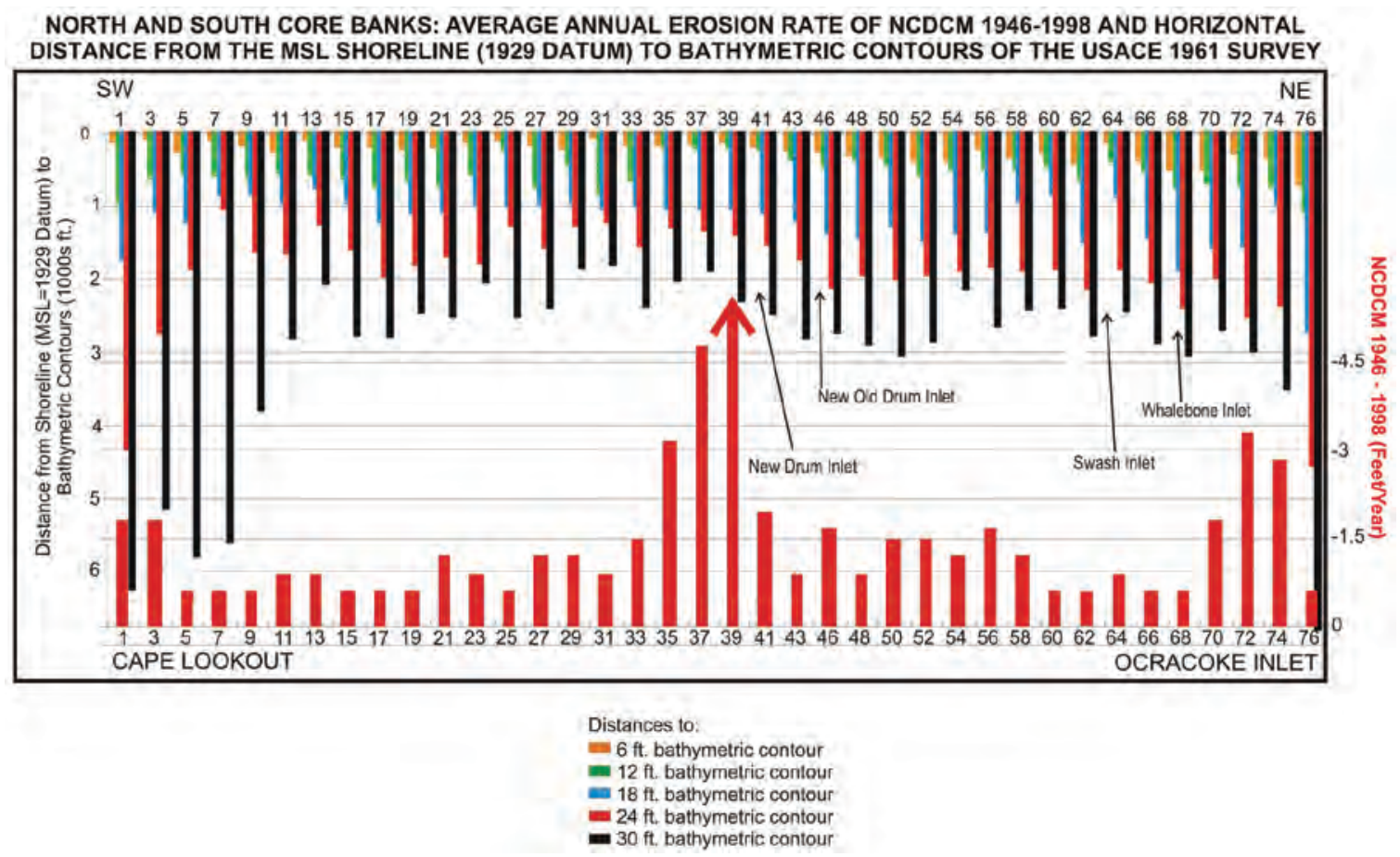

Figure 14. Horizontal distance from the shoreline seaward to the 6-, 12-, 18-, 24-, and 30-foot depth contours for all alternate profiles from the U.S. Army Corps of Engineers 1961 survey, plotted opposite the long-term NCDCM 1946-1998 average annual shoreline erosion rates in feet/year, (bottom panel and right-hand axis) for Core Banks, Cape Lookout National Seashore, North Carolina. Water depth is based on the 1929 MSL datum.

\section{Godfrey and Godfrey Data Sets}

The shoreline erosion data from the G\&G 1971 survey are listed in appendix 4. The G\&G 1971 survey only measured the horizontal shoreline change on 39 selected profiles (fig. 15). Because the original G\&G 1971 survey data are not available in the public domain, the G\&G 1971 data were interpreted from a graphic plot (Godfrey and Godfrey, 1976, fig. 37). The interpreted data are presented as approximate erosion rates for 1962-1971 in figure 15. The overall error in interpreting the graphic plot to obtain a numerical data set (appendix 4) was statistically determined to be $+/-0.6$ percent. The maximum and average annual rates of erosion and accretion from the G\&G 1962-1971 survey are summarized in table 1 . The average annual accretion rate for the 9-year period (1962-1971) was $+12 \mathrm{ft} / \mathrm{yr}$, with a maximum erosion of $-11 \mathrm{ft} /$ $\mathrm{yr}$ and a maximum accretion of $+55 \mathrm{ft} / \mathrm{yr}$.

A histogram of shoreline change that compares the difference between the G\&G 1971 survey data (blue) and the USACE 1960-1962 survey data (red) is shown in figure 16. The USACE 1960-1962 shoreline change data (USACE, 1964) are overwhelmingly dominated by erosion in response to Hurricane Donna in 1960 and the Ash Wednesday nor'easter in 1962. In comparison, the shoreline change data for the G\&G 1962-1971 survey are overwhelmingly dominated by shoreline accretion.

Statistical comparison between the G\&G and the USACE survey data suggest very poor to no correlation. The G\&G 1962-1971 survey represents a time of low storm activity. According to Barnes (2001), low storm activity began after the Ash Wednesday Storm of 1962 and concluded when Hurricane Ginger came ashore in late 1971. These data suggest that 1963-1970 was generally an accretionary period for Core Banks with an average annual accretion rate of $+12 \mathrm{ft} / \mathrm{yr}$ (table 1). Thus, the Core Banks shoreline was generally accreting the beaches following the severe impacts of the 1960 and 1962 storms that dominated the USACE surveys. 


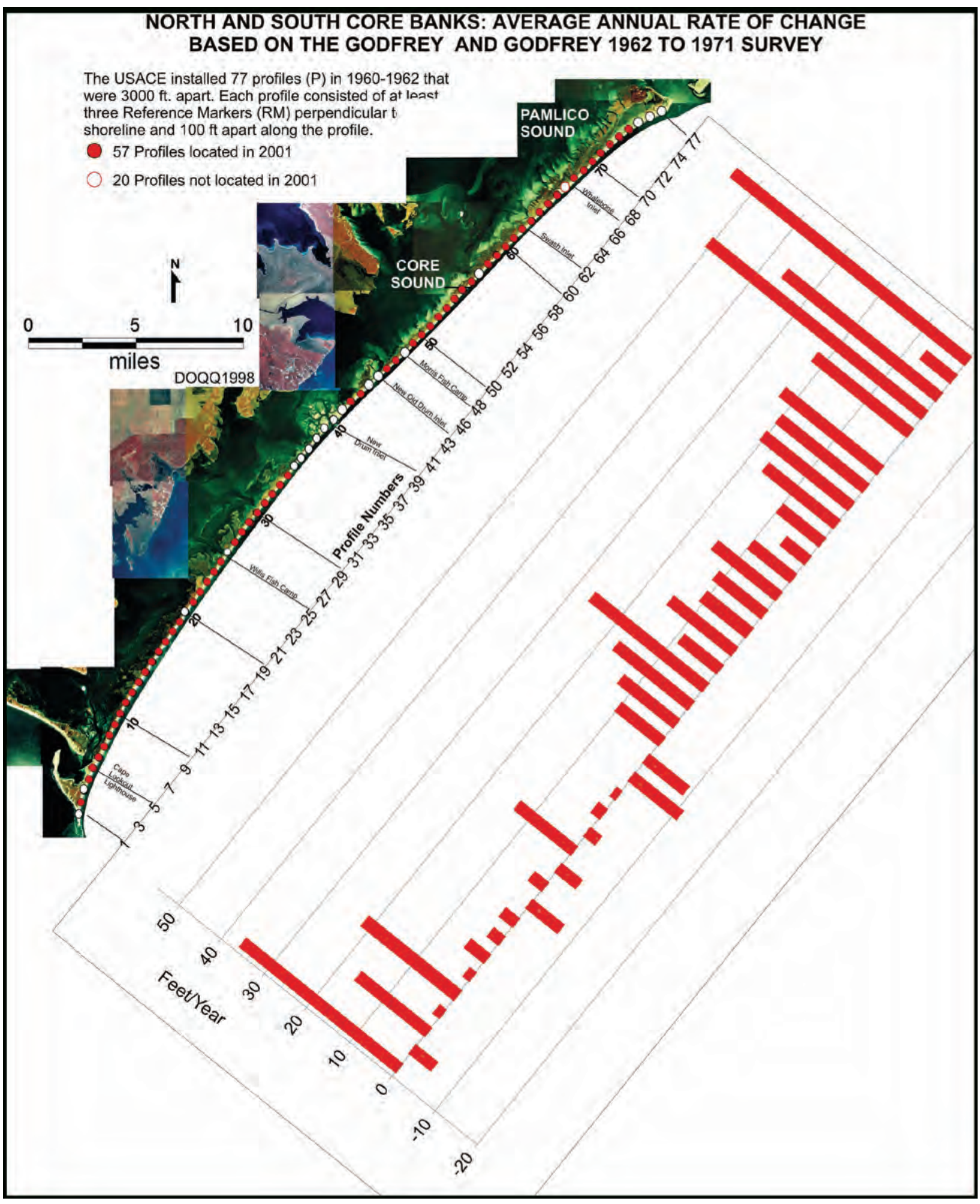

Figure 15. The average rate of shoreline change between the USACE 1962 survey and the Godfrey and Godfrey 1971 survey for Core Banks, Cape Lookout National Seashore, North Carolina. Data are listed in appendix 4. Because the original survey data of Godfrey and Godfrey are not available in the public domain, the data presented here are interpreted from a graphic plot (Godfrey and Godfrey,1976, fig. 37). 


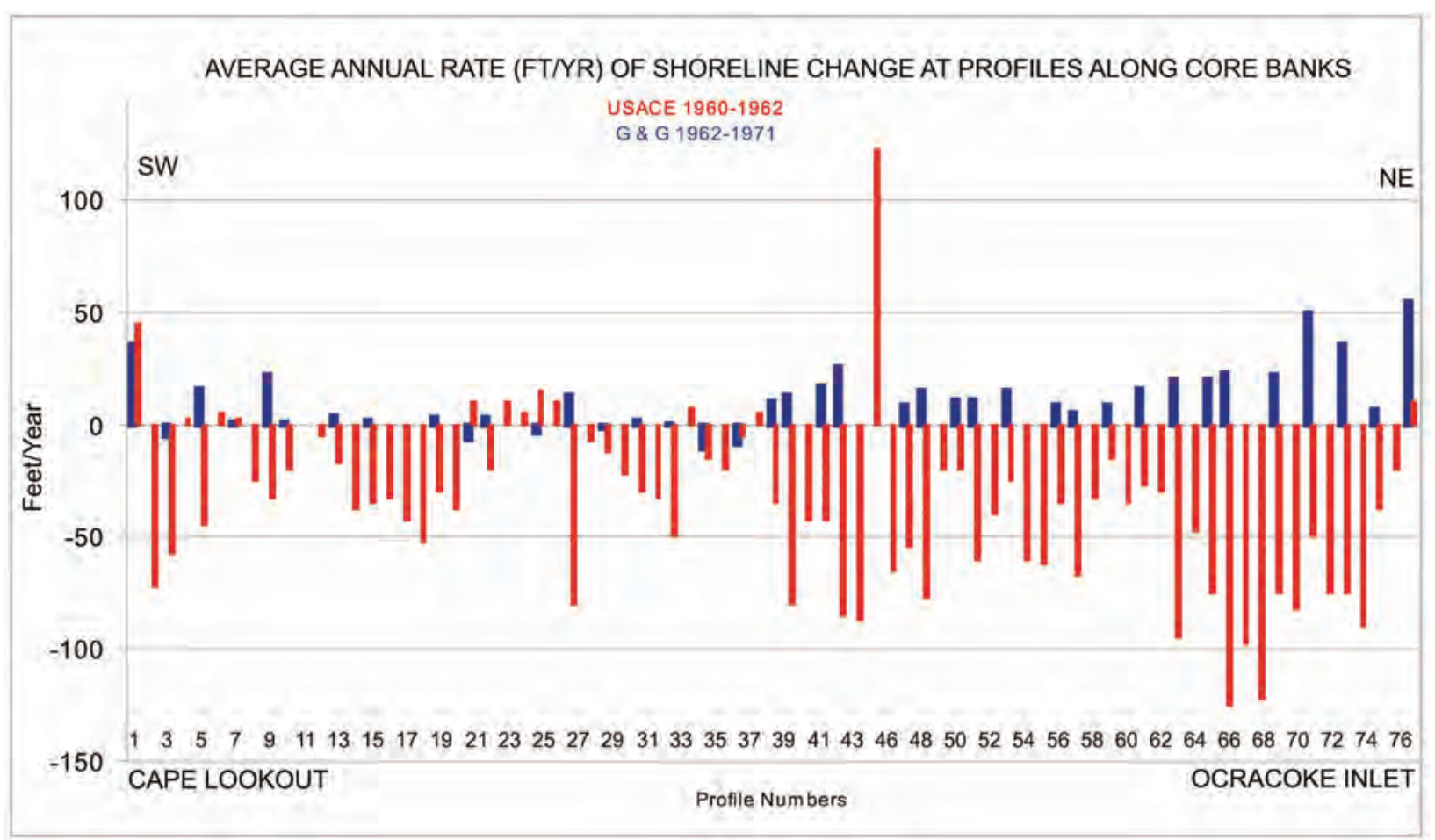

Figure 16. Average annual rate of shoreline erosion and accretion from the U.S. Army Corps of Engineers 1960-1962 survey data (red) and the Godfrey and Godfrey 1962-1971 survey data (blue), Core Banks, Cape Lookout National Seashore, North Carolina. Data are listed in appendix 1 and appendix 4, respectively. The short-term data of the USACE 1960-1962 survey reflects two very large storms with major shoreline changes that were dominantly erosional. In contrast, the G\&G 1962-1971 survey was a period of little to no storm activity and thus the shoreline demonstrates a pattern of mostly accretion. The gaps in the $G \& G$ survey do not mean that these profiles were destroyed or lost, rather, their survey only measured 39 of the USACE profiles. Because the original survey data of Godfrey and Godfrey are not available in the public domain, the data presented here are interpreted from a graphic plot (Godfrey and Godfrey,1976, fig. 37).

The elevation change data from the reference markers located by the G\&G survey are listed in appendix 3 . According to figure 20 in Godfrey and Godfrey (1976), the elevation data were obtained in 1970 and compared to the elevation data resulting from the 1960 USACE survey. Because the elevation data from the G\&G survey are presented only as a graphic plot (Godfrey and Godfrey, 1976, fig. 20), the numerical data presented here are approximations developed from these plots. The overall error in interpreting the graphic plot to obtain a numerical data set (appendix 3 ) was statistically determined to be $+/-0.6$ percent. The G\&G 1970 survey located 141 reference markers on 69 of the original 77 profiles and measured the vertical change in elevation of the sediment relative to the USACE reference markers. Elevation change results are summarized in table 3.
The period of low storm activity from 1962 to 1971 was broken shortly after the G\&G 1971 summer survey was completed. Hurricane Ginger came ashore at Core Banks on September 30, 1971 with substantial shoreline recession and vertical accretion. The post-storm accretionary response suggested by the G\&G 1962-1971 survey data, is strongly supported on a smaller time scale by a series of cross-island topographic profiles produced by Godfrey and Godfrey (1976). The topographic profile at Codds Creek on South Core Banks (fig. 17) shows the pre-Ginger geomorphic profile surveyed in August 1971, the post-Ginger profile from October 1971, and the later post-Ginger profile from July 1972. Hurricane Ginger caused the upper beach face to recede landward about $127 \mathrm{ft}$. Ten months later, the upper beach face had accreted about $157 \mathrm{ft}$ seaward with the shoreline building about $12 \mathrm{ft}$ seaward of the original August 1971 shoreline. 
Table 3. Summary of the elevation data for 141 reference markers on 69 profiles from the 1970 Godfrey and Godfrey survey for Core Banks, Cape Lookout National Seashore, North Carolina.

[G\&G, Godfrey and Godfrey. Number of reference markers and profiles in the G\&G survey is out of the original 231 RM-0s, RM-1s, and RM-2s that the U.S. Army Corps of Engineers installed on 77 profiles. All elevations are in relation to mean sea level (1929 datum). See appendix 3 and fig. 20 (Godfrey and Godfrey, 1976) for data]

\begin{tabular}{|c|c|c|c|c|c|c|c|c|}
\hline Reference markers & \multicolumn{2}{|c|}{ RM-0s } & \multicolumn{2}{|c|}{ RM-1s } & \multicolumn{2}{|c|}{ RM-2s } & \multicolumn{2}{|c|}{$\begin{array}{l}\text { All reference } \\
\text { markers } \mathbf{R M s}^{1}\end{array}$} \\
\hline G\&G 1970 Total number of reference markers located & 36 & 47 & 46 & 60 & 59 & 77 & 158 & 60 \\
\hline G\&G 1970 Reference markers with accretion or no change & 19 & 53 & 37 & 80 & 51 & 86 & 109 & 69 \\
\hline G\&G 1970 Reference markers with deflation & 17 & 47 & 9 & 18 & 8 & 14 & 49 & 31 \\
\hline G\&G 1970 Average ground elevation (in feet) & \multicolumn{2}{|c|}{+6.7} & \multicolumn{2}{|c|}{+6.4} & \multicolumn{2}{|c|}{+6.1} & \multicolumn{2}{|c|}{+6.1} \\
\hline G\&G 1970 Maximum ground elevation (in feet) & \multicolumn{2}{|c|}{+9.9} & \multicolumn{2}{|c|}{+10.0} & \multicolumn{2}{|c|}{+10.5} & \multicolumn{2}{|c|}{+10.5} \\
\hline
\end{tabular}

${ }^{1}$ Includes all reference markers located by G\&G in 1970 from RM-0 through RM-2 plus others through RM- 8 of the 264 RMs established by the USACE in 1961 (see appendixes 1 and 3).

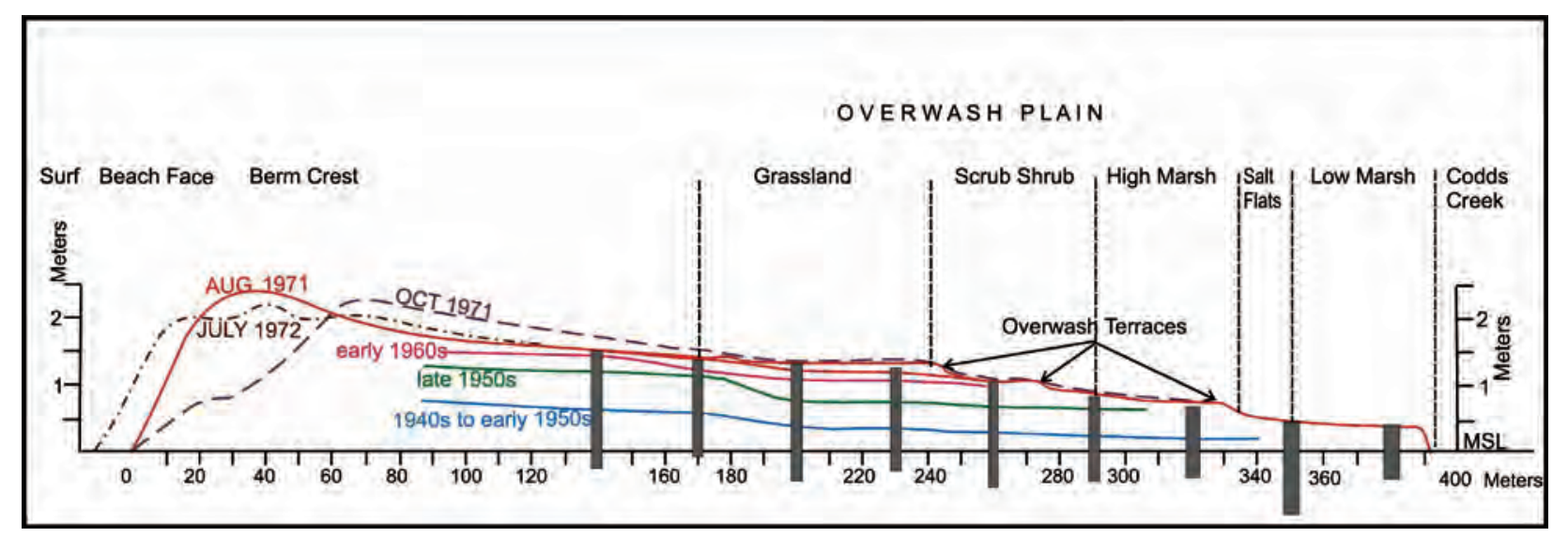

Figure 17. Cross-sectional profile of South Core Banks at Codds Creek showing the shallow stratigraphic interpretation of the history of overwash fan deposition developed from a series of trenches dug across the island (Godfrey and Godfrey, 1976). The initial topographic profile survey was in August 1971. Hurricane Ginger came ashore in October 1971 and severely eroded the upper beach face of the beach profile. A third profile (July 1972) demonstrates the post-storm recovery-the upper beach face and shoreline is located seaward of the pre-Hurricane Ginger profile in August 1971. (Modified from Godfrey and Godfrey, 1976.) 


\section{East Carolina University Data Sets}

Data from the ECU 2001 survey are presented in appendixes 5 and 6 . All reference markers located in the ECU 2001 survey, along with their latitude and longitude are shown in appendix 5. Appendix 6, column I lists the ECU 2001 survey data obtained for the recovered reference markers as part of the present study. Column J lists the net shoreline change between the USACE 1960 and ECU 2001 surveys based on the MSL 1929 datum. Column K lists the ECU 2001 sediment surface height above or below the reference marker datum of the USACE. Column L lists the corrected height above the MSL 1929 datum. Column M lists the net change in surface elevation (accretion versus deflation) between the USACE 1961 and ECU 2001 surveys relative to the MSL 1929 datum.

Figure 18 shows the net shoreline erosion in feet (red) and average annual rate of erosion in feet per year (blue) based on the ECU 1960-2001 survey (appendix 6). These data were developed for 57 profiles where the USACE (1964) reference markers were recovered and are plotted on the 1998 DOQQ aerial photograph mosaic as red circles (fig. 9). Profiles that were not located in the 2001 survey are marked with white circles. The maximum and average annual rates of erosion and accretion resulting from the ECU 1960-2001 survey are shown in table 1 . The average annual erosion rate for the 41-year period (1960-2001) was -5 ft/yr, with a maximum annual erosion rate of $-19 \mathrm{ft} / \mathrm{yr}$ and a maximum annual accretion rate of $0 \mathrm{ft} / \mathrm{yr}$ (fig. 18).

Following the Godfrey and Godfrey survey of 1971, the North Carolina coastal area experienced a moderate degree of storminess through 1990 (Barnes, 2001) with four hurricanes and one major nor'easter storm that impacted the shoreline along Core Banks. This was followed by an intense period of storminess that began in 1991 with 13 minor hurricanes that impacted the net shoreline recession of the North Carolina Outer Banks; 9 of these storms occurred before the ECU 2001 survey.

The relationship of the average annual shoreline change rates between the USACE 1960-1962 data set and the ECU 1960-2001 data set is presented in figure 19. The correlation coefficient for these two data sets is +0.55 suggesting a positive correlation between the net short-term, erosiondominated USACE data and longer-term, erosion-dominated ECU data. The USACE short-term data set directly reflects the mitigating forces of two very different types of storm influences, whereas the long-term ECU data set consists of periods of low and high storm activity. Both the USACE 1960-1962 and ECU 1960-2001 data sets are overwhelmingly dominated by shoreline erosion (fig. 19).
The scale of the USACE and ECU data sets is very different. As indicated in table 1, the short-term USACE data (1960-1962) show average annual rates of shoreline change that range from $-97 \mathrm{ft} / \mathrm{yr}$ erosion to $+45 \mathrm{ft} / \mathrm{yr}$ accretion, with an average net change of $-36 \mathrm{ft} / \mathrm{yr}$. In comparison, the longterm ECU data (1960-2001) suggest average annual rates of shoreline change that range from $0 \mathrm{ft} / \mathrm{yr}$ to $-19 \mathrm{ft} / \mathrm{yr}$ erosion, with an average net change rate of $-5 \mathrm{ft} / \mathrm{yr}$. In order to show these data on the same plot in figure 19, the long-term scale is different for each plot.

A histogram of the shoreline change data from the ECU 1960-2001 data set and the G\&G 1962-1971 survey demonstrates the difference between these two data sets (fig. 20). The ECU 1960-2001 data set is characterized by average annual rates of shoreline change that range from a low of $0 \mathrm{ft} / \mathrm{yr}$ to a high of $-19 \mathrm{ft} / \mathrm{yr}$, with an average annual net change of $-5 \mathrm{ft} /$ yr. This is compared to the G\&G 1962-1971 data set with an average annual rate of shoreline change that ranges from a maximum erosion rate of $-11 \mathrm{ft} / \mathrm{yr}$ to a maximum accretion rate of $+55 \mathrm{ft} / \mathrm{yr}$, with an average annual net change of $+12 \mathrm{ft} / \mathrm{yr}$. The long-term, higher-storm period of the ECU 1960-2001 data are dominated by erosion, whereas the shorter-term, low storm period of the G\&G 1962-1971 data are dominated by accretion. The correlation coefficient between these two data sets is -0.68 , which supports this interpretation.

The net increase in elevation between the USACE 1961 and the ECU 2001 surveys is shown in figure 21. Elevations at the top of each reference marker and at the ground surface were measured by the USACE in 1961 (appendix 1, columns $\mathrm{C}$ and D, respectively). The ECU 2001 survey measured the ground height above or below the top of each reference marker (appendix 6, column K). From these data, 2001 ground elevations were determined (appendix 6, column L). The difference between ground elevation in 2001 and 1961 is the net change in ground elevation and is shown in appendix 6 (column M). Figure 21 shows net elevation change for three reference markers $(\mathrm{RM}-0=$ blue, $\mathrm{RM}-1=$ red, and $\mathrm{RM}-2=$ green $)$ along profiles where they were located. The graph is plotted along the 1998 DOQQ mosaic to allow comparison of elevation change to processes occurring on Core Banks.

The fewest number of reference markers located by the ECU 2001 survey was for the ocean front row of markers; 15 RM-0s were located, as compared to 33 RM-1s and 35 RM-2s (table 4). All located reference markers accreted sand; the greatest amount of accretion was closest to the ocean shoreline and generally decreased inland. The average ground elevation for the different sets of reference markers is as follows: RM-0 $=+10.1 \mathrm{ft}, \mathrm{RM}-1=+9.1 \mathrm{ft}$, and $\mathrm{RM}-2=+8.5 \mathrm{ft}$. 


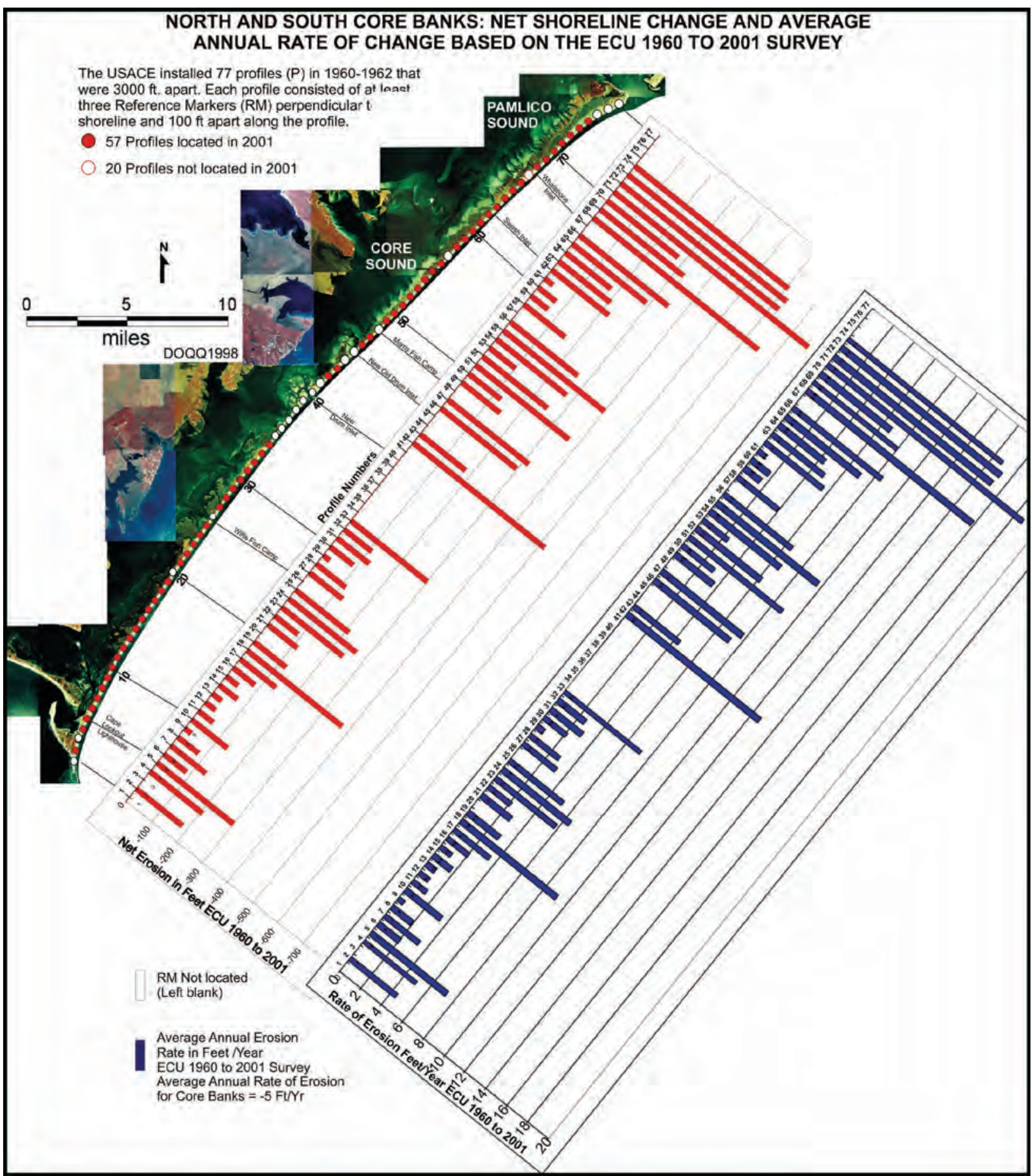

Figure 18. Net shoreline change (red) and average annual rate of change (blue) from the East Carolina University 1960-2001 survey for each profile where the U.S. Army Corps of Engineers reference markers were recovered, Core Banks, Cape Lookout National Seashore, North Carolina. Data are listed in appendix 6. Profiles with USACE reference markers that were located in the ECU 2001 survey are marked with red circles. Profiles that were not located are marked with white circles. The data are plotted along the 1998 D000 mosaic for Core Banks. 
AVERAGE ANNUAL RATE OF SHORELINE CHANGE AT PROFILES ALONG CORE BANKS

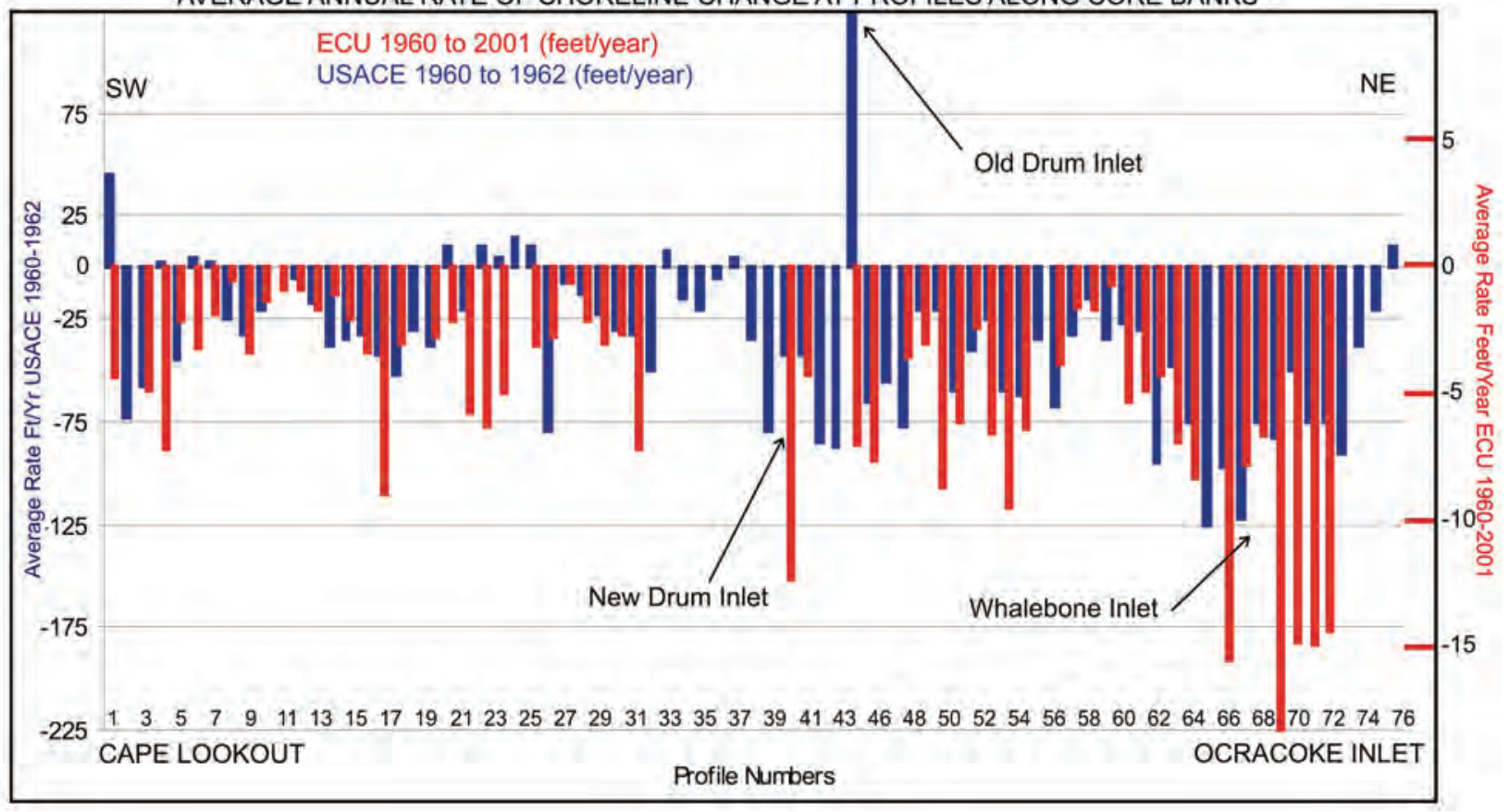

Figure 19. Average annual rate of shoreline change from the U.S. Army Corps of Engineers 1960-1962 surveys (blue) for the 77 USACE profiles and the East Carolina University 1960-2001 survey (red) for the 57 profiles where one or more of the U.S. Army Corps of Engineers reference markers were recovered, Core Banks, Cape Lookout National Seashore, North Carolina. Data are listed in appendix 1 and appendix 6, respectively. The short-term data of the USACE 1960-1962 survey reflect two very large storms with major shoreline changes and are plotted in feet per year. In contrast, the long-term data of the ECU 1960-2001 survey include extended periods of little to no storm activity. This caused erosion rates to be substantially decreased, and reflects the contrasting responses to different types and intensities of storms. Notice the two $y$-axes have different scales. 


\section{AVERAGE ANNUAL RATE (FT/YR) OF SHORELINE CHANGE AT PROFILES ALONG CORE BANKS}

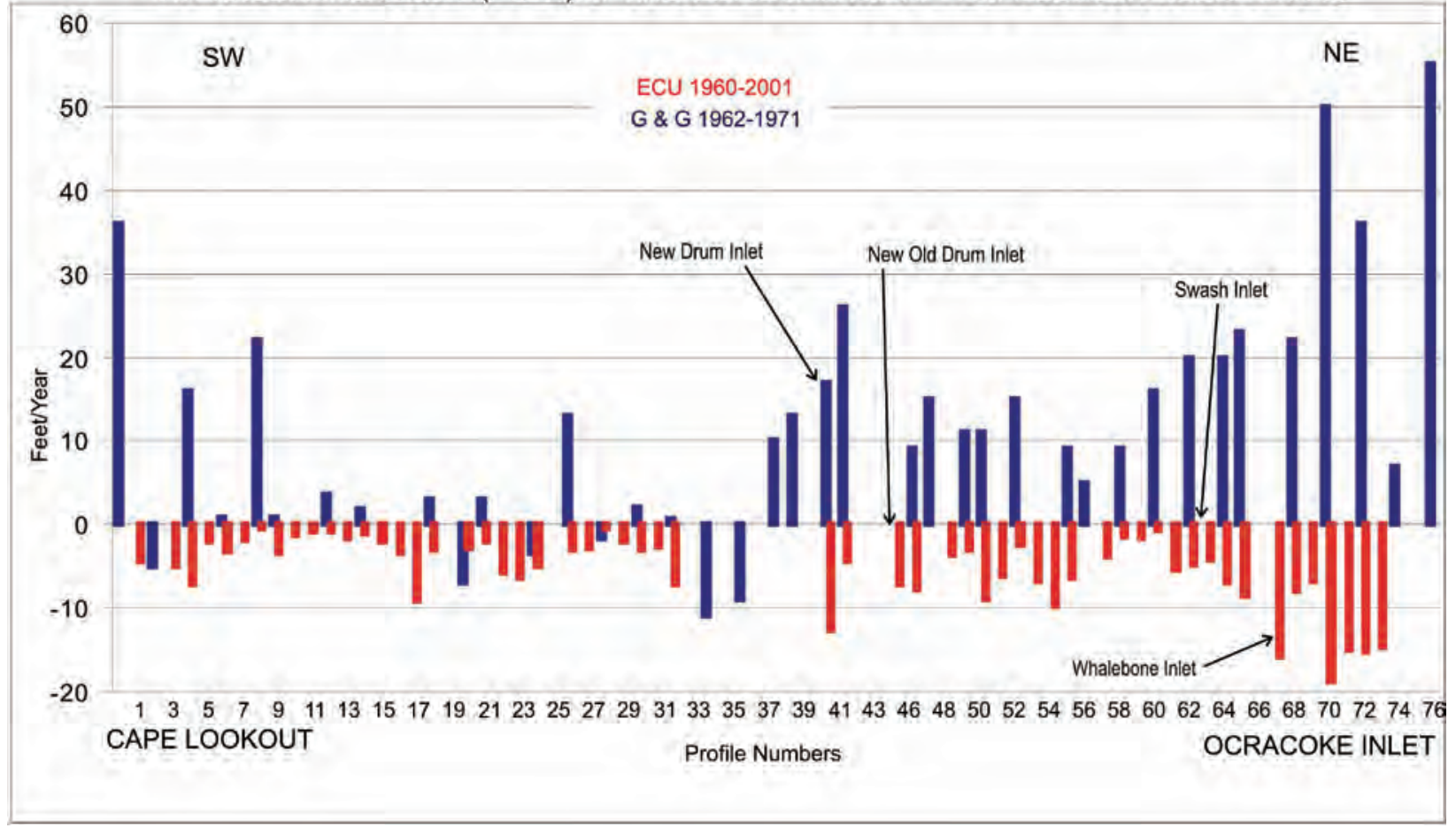

Figure 20. Average annual rate of shoreline change from the Godfrey and Godfrey 1962-1971 survey (blue) and the East Carolina University 1960-2001 survey (red), Core Banks, Cape Lookout National Seashore, North Carolina. Data are listed in appendix 4 and appendix 6, respectively. The short-term data of the G\&G 1962-1971 survey represents mainly accretion during a period of low storm activity following the two very large storms in 1960 and 1962. In contrast, the long-term data of the ECU 1962-2001 survey include both non-stormy and stormy periods and therefore, show small net rates of shoreline erosion. The G\&G survey only included 39 selected profiles of the original 77 USACE profiles, whereas the ECU 1960-2001 survey located 57 of the original 77 profiles. 


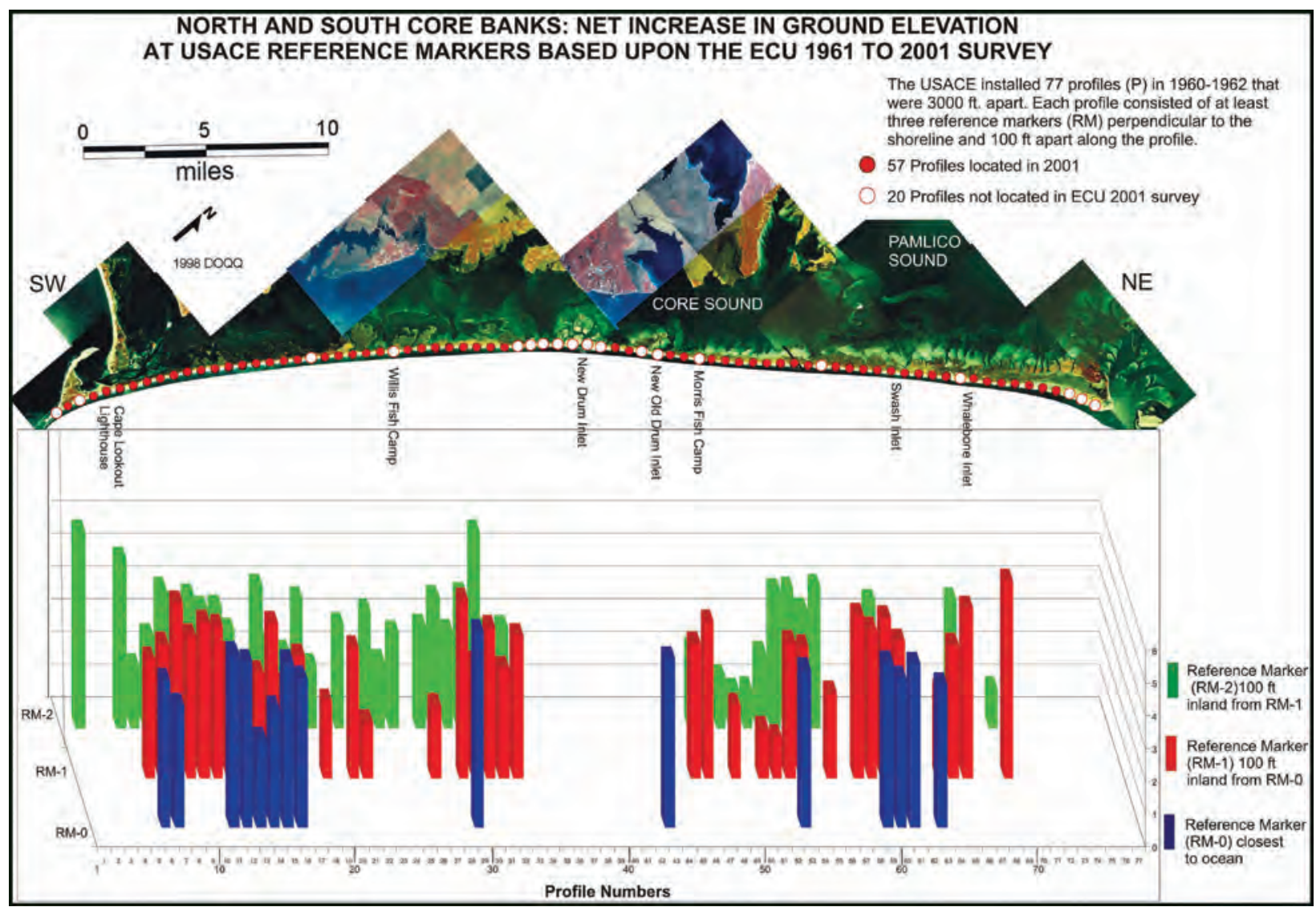

Figure 21. Net increase in ground elevation at U.S. Army Corps of Engineers (USACE) reference markers (RM-0 = blue, $\mathrm{RM}-1$ = red, and RM-2 = green) based on changes between the USACE 1961 and East Carolina University 2001 surveys for each profile where USACE reference markers were recovered, Core Banks, Cape Lookout National Seashore, North Carolina. Data are listed in appendix 2 and appendix 6, respectively. Profiles with USACE reference markers that were located in the ECU 2001 survey are marked with red circles. Profiles that were not located are marked with white circles. Data are plotted along the 1998 D000 mosaic for Core Banks. 
Table 4. Summary of the elevation data for 83 reference markers on 57 profiles from the East Carolina University 2001 survey for Core Banks, Cape Lookout National Seashore, North Carolina.

[ECU, East Carolina University. Number of reference markers and profiles in the ECU survey is out of the original 77 RM-0s, 77 RM-1s, and 77 RM-2s that the U.S. Army Corps of Engineers installed on 77 profiles. All elevations are in relation to mean sea level (1929 datum). See appendix 6 for data]

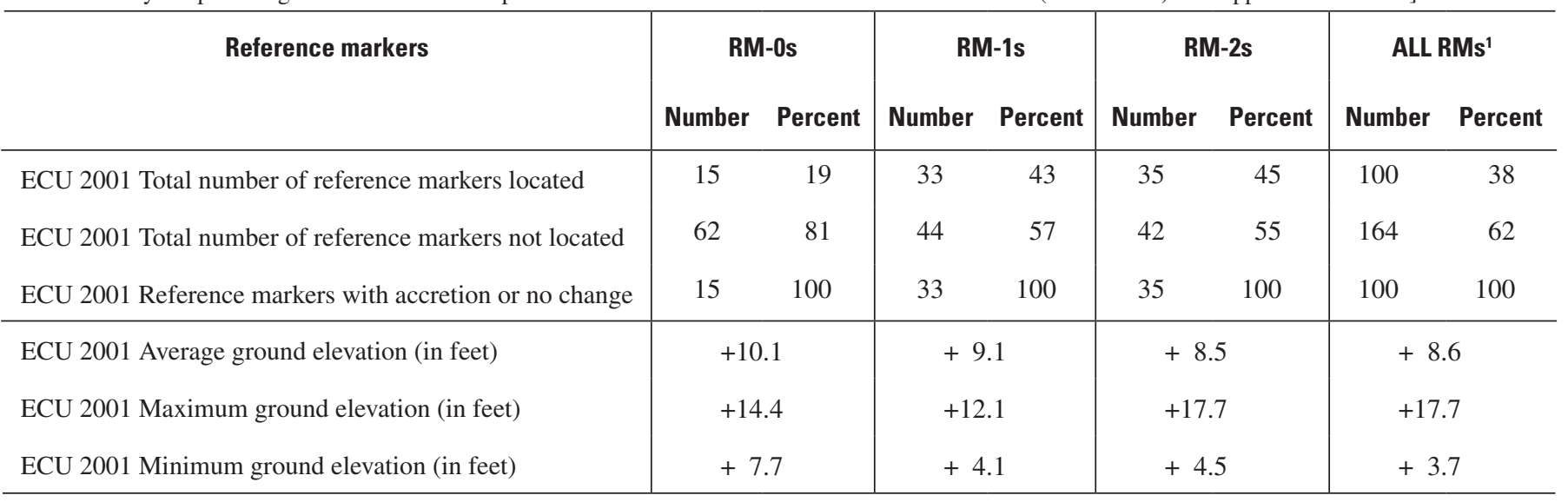

${ }^{1}$ Includes all reference markers from RM-0 through RM-2 plus all others through RM-8 that were established by the USACE in 1961 (total RMs $=264$ ) (see appendixes 1 and 6).

\section{North Carolina Division of Coastal Management Data Sets}

Data for the average annual rate of shoreline erosion from the North Carolina Division of Coastal Management (NCDCM 1940-1992 and NCDCM 1946-1998 data sets) for Core Banks (Benton and others, 1993; 1997; 2004) is summarized in appendix 7. NCDCM subdivided the coast into segments of similar erosion rates and labeled each segment with its long-term average annual erosion rate factor. To correlate the NCDCM data to the USACE profiles on Core Banks, the 77 USACE profiles were superimposed on the appropriate coastal segments to obtain the NCDCM average annual erosion rate factor for each profile. The resulting two NCDCM data sets are plotted as histograms on figure 22 .

The maximum and average annual rates of erosion and accretion from the most recent NCDCM 1946-1998 survey are summarized in table 1 . The average annual erosion rate for the 52-year period was $-5 \mathrm{ft} / \mathrm{yr}$, with a maximum annual erosion rate of $-30 \mathrm{ft} / \mathrm{yr}$ and a minimum annual erosion rate of $<-2 \mathrm{ft} / \mathrm{yr}$ (fig. 22).

The NCDCM data set for 1946-1998 (52 years) is the longest data set in the present study. The average annual erosion rate for all of Core Banks in the NCDCM data set ranges from maximum erosion of $-30 \mathrm{ft} / \mathrm{yr}$ to a minimum of $<-2 \mathrm{ft} / \mathrm{yr}$ with an average annual erosion rate of $-5 \mathrm{ft} / \mathrm{yr}$ (table 1). This compares well with the average annual erosion rate for the ECU data set, which ranges from a maximum erosion rate of $-19 \mathrm{ft} / \mathrm{yr}$ to a minimum of $0 \mathrm{ft} / \mathrm{yr}$ and an average annual erosion rate of $-5 \mathrm{ft} / \mathrm{yr}$ (table 1). All 57 of the 77 profiles located by the ECU survey showed net long-term shoreline erosion (fig. 23), and it appears that the NCDCM data are similar. On the NCDCM maps, however, no segments have an average annual erosion rate of less than $-2 \mathrm{ft} / \mathrm{yr}$. This is based on the assumption that the entire shoreline is eroding. The NCDCM regulations for oceanfront development require using a minimum of $-2 \mathrm{ft} / \mathrm{yr}$ erosion rate for house construction setback rules (Benton and others, 1993; 1997). The close similarity between the ECU and NCDCM long-term data sets, using different survey methods, corroborates the general overall erosion rates for the North Carolina ocean shoreline.

Statistical comparison of the NCDCM 1946-1998 survey data with the ECU 1960-2001 long-term (41-year) data set (fig. 23), produces a moderately good positive correlation of +0.62 . This correlation occurs even though the NCDCM data are based on different survey methods from those used by USACE and ECU and demonstrates that erosion dominated the Core Banks shoreline during the long-term time frame (fig. 23). 


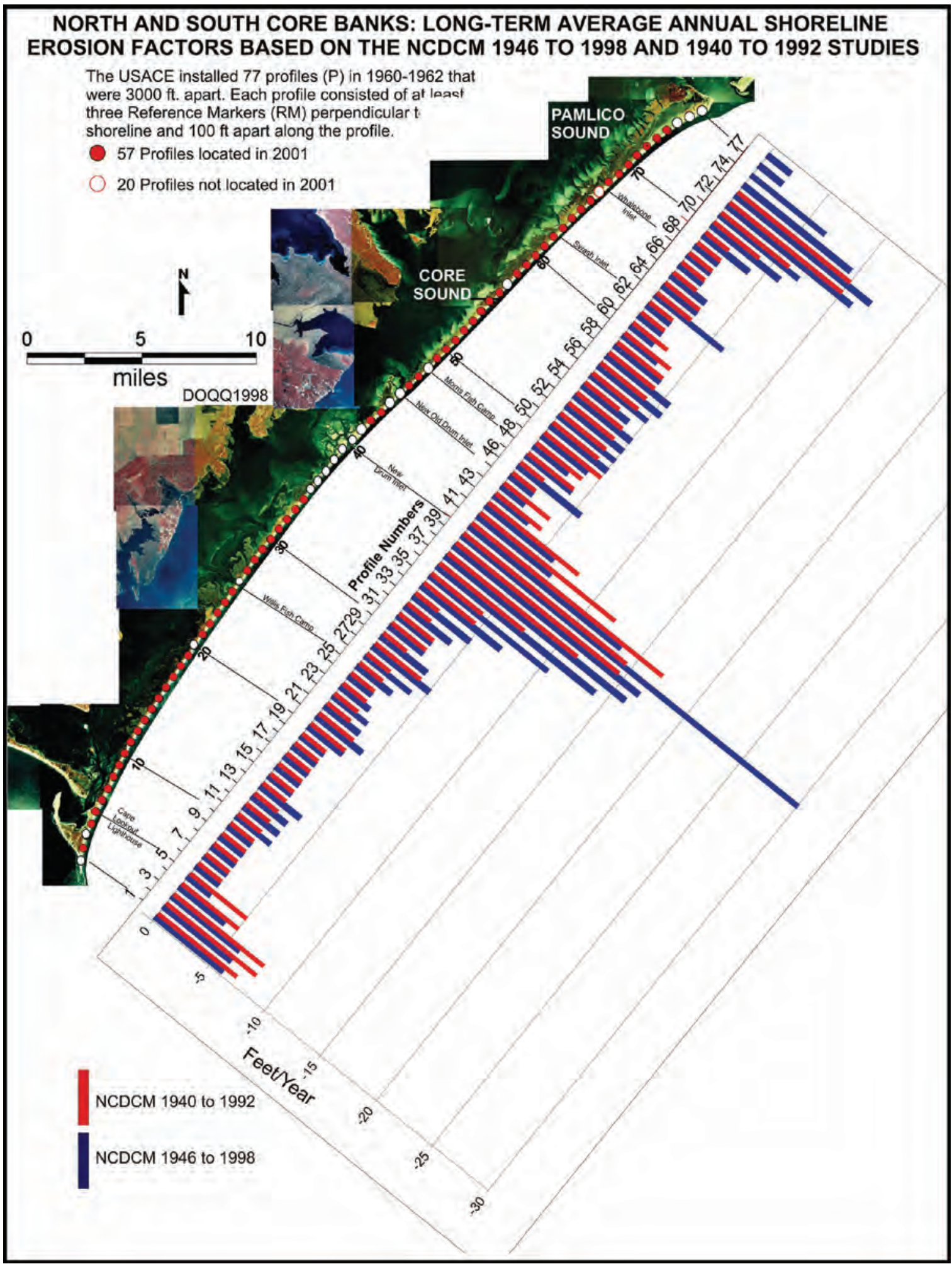

Figure 22. Shoreline change data from the North Carolina Division of Coastal Management 1940-1992 and 1946-1998 data sets, Core Banks, Cape Lookout National Seashore, North Carolina. Data are listed in appendix 7. Data for the 1940-1992 period are from Benton and others (1993) and the 1946-1998 period are from Benton and others (1997). The straight line data at the $-2 \mathrm{ft} / \mathrm{yr}$ level are based on the assumption that all shorelines are receding over the long term. This is the number used by NCDCM as the minimum rate of shoreline recession for their regulatory program. 


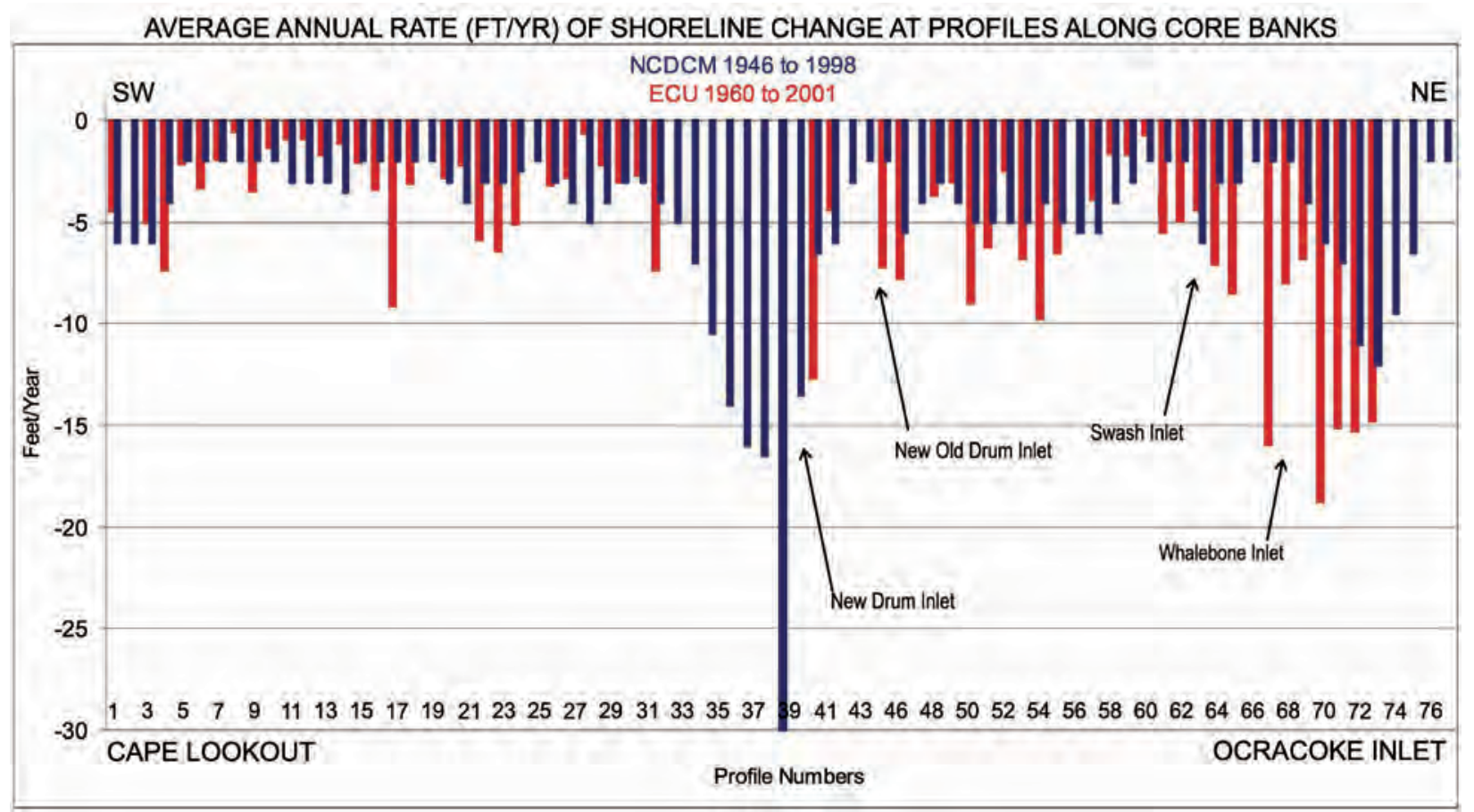

Figure 23. Average annual rate of shoreline change from the long-term East Carolina University 1960-2001 data set (red) and the long-term North Carolina Division of Coastal Management (1946-1998 data set (blue), Core Banks, Cape Lookout National Seashore, North Carolina. Data are listed in appendix 6 and appendix 7, respectively. Gaps in the ECU 1960-2001 plot represent profiles where no reference markers were located. The straight line data at the $-2 \mathrm{ft} / \mathrm{yr}$ level is based on the assumption that all shorelines are receding over the long term. This is the number used by NCDCM as the minimum rate of shoreline recession for their regulatory program.

\section{Patterns of Shoreline Change Along Core Banks}

The opening, migration, and closing of inlets plays an extremely important role in determining the erosion and accretion patterns of sediments in the adjacent shoreline segments. Three distinctive patterns are seen in all shoreline change data sets used in this study.

1. At the large scale of the entire Core Banks, erosion and accretion rates are greatest near Ocracoke Inlet and generally decrease southwestward towards the Cape Lookout Lighthouse. The rates then increase to intermediate levels towards Cape Lookout. Both Ocracoke Inlet and Cape Lookout play major but different roles in controlling the overall barrier island response.

2. The general cuspate pattern of Core Banks (fig. 1) is broken in the middle by the two small, but semi-permanent Drum Inlets (fig. 2). Erosional and accretional processes are generally high adjacent to New Drum and New-Old Drum Inlets and fluctuate as a direct function of inlet dynamics (opening, migration, and closing) in direct response to specific weather patterns and storm events (figs. 12, 15, 18, and 22).

3. Superimposed on top of the large-scale, cuspate erosion pattern is a series of smaller-scale features that are characterized by higher or lower erosion rates.

These local features are related to one of several specific shoreline characteristics.
A. Changes in shoreline and shoreface geometry often reflect changes in the geologic materials underlying the barrier island. Figures 24A and 24B are oblique aerial photographs that show significant bends in the shoreline near P34-P35 and P57-P58, respectively. Each of these areas represents the steepest shoreface profiles measured by the USACE survey (fig. 13). The P34-P35 area of South Core appears to be located on the axis of the Cape Lookout High, an upper Tertiary paleotopographic limestone ridge that separated the Onslow Embayment from the Aurora Embayment (Snyder and others, 1990). Preliminary analysis of nearshore, side-scan sonar and high-resolution seismic data suggest that this area may be dominated by hard bottoms that extend up into the shallow shoreface (E.R. Thieler, U.S. Geological Survey oral comm., 2005). The P57-P58 area of North Core is probably characterized by peat outcrops of the back-barrier marsh platforms that have been overridden by the shoreline as the barrier island recedes (fig. 13). Both of these areas are characterized today by generally low rates of long-term erosion (fig. 23).

B. Low and narrow barrier island segments are weak spots that are often characterized by major overwash events or the frequent opening and closing of ephemeral inlets such as Whalebone, Swash, and Sand 
Inlets on North Core Banks (fig. 3). These areas need overwash and inlets to build both elevation and width to the barrier island and adjacent back-barrier areas. As these ephemeral inlets open and close, the adjacent areas are characterized by periods of major erosion or accretion, respectively (figs. 12 and 23).

The average annual shoreline erosion and accretion data for all data sets used in the present study are summarized in table 5 for North and South Core Banks. The average annual rates of erosion are substantially higher for North Core Banks relative to South Core Banks in most data sets, by a factor from 2 to 5 . In general, the highest rates of erosion are on North Core Banks near P69 (fig. 23) at the southwestern end of the Portsmouth Overwash Plain and northeast of Whalebone Inlet. The erosion rates rapidly decrease to the northeast towards the road to Portsmouth Village (X on figs. 3 and $24 \mathrm{C}$ ), where the shoreline becomes strongly accretionary in response to wave refraction around the Ocracoke Inlet ebbtide delta (Hayes, 1976).

High erosion rates occur near the two Drum Inlets that separate North Core Banks from South Core Banks. The average annual rates of erosion decrease southwest of the two Drum Inlets to the generally lowest erosion rates in the P5-P20 part of South Core Banks (fig. 23). Within this area of lowest erosion rates, many of the RM-0, RM-1, and RM-2 reference markers that were recovered by the ECU 2001 survey were buried by 3 to $5 \mathrm{ft}$ of sand (fig. 25). Towards Cape Lookout, southwest of P5, the shoreface slope decreases dramatically as the shoreline approaches Cape Lookout Shoals (fig. 12) and the erosion rates generally increase to intermediate levels (fig. 23) in response to the severe waves around the Cape and associated Cape Lookout Shoals (fig. 1).
None of the reference markers associated with the last three profiles adjacent to Ocracoke Inlet (P75-P77) were recovered in the ECU 2001 survey. It is believed that this end of Portsmouth Island is accretionary in both the horizontal and vertical directions. This accretion is in direct response to the wave refraction around the ebb-tide delta of Ocracoke Inlet-the resulting depositional pattern is generally called the "drumstick effect" (Hayes, 1976) and can be seen in figure 3. Deposition of the massive field of foredunes that formed along the eastern edge of the Portsmouth Overwash Plain (fig. 24C) would have buried the reference markers beneath a thick sequence of new dune sand. Based on aerial photograph timeslice analysis of the Portsmouth area (figs. 3B and 3C) and the 2001 oblique aerial photograph (fig. 24C), these foredunes have been accreting since the 1962 Ash Wednesday storm.

To the southwest of P74, the shoreline changes from accretional to erosional; the rate of erosion increases rapidly to a maximum around P71 and then declines to a minimum erosion rate around P59 (fig. 23). This erosional minimum is in the general location of a series of smaller, ephemeral inlets in North Core Banks, including Whalebone and Swash Inlets (fig. 3). The moderate amounts of accretion near P62 and erosion near P68 are associated with the ephemeral Swash and Whalebone Inlets, respectively (fig. 23). The erosion rate generally increases in the area near P59 to a maximum rate in the area near P51. The rate then decreases in the area near P43, which is the site of New-Old Drum Inlet, characterized by very low recession rates (fig. 23).

The two Drum Inlets play a major role in the patterns of shoreline erosion and accretion in the central Core Banks area (fig. 2). New Drum Inlet (fig. 24A) was opened in December 1971 by the USACE, and Old Drum Inlet, which closed naturally in January 1971, was reopened by Hurricane Dennis

Table 5. Maximum and average annual rates of shoreline erosion and accretion for each of the shoreline surveys or data sets for North and South Core Banks, Cape Lookout National Seashore, North Carolina.

[USACE, U.S. Army Corps of Engineers; G\&G, Godfrey and Godfrey; ECU, East Carolina University; NCDCM, North Carolina Division of Coastal Management; ft/yr, feet per year]

\begin{tabular}{|c|c|c|c|c|c|c|}
\hline \multirow{3}{*}{$\begin{array}{c}\text { Surveys } \\
\text { or data sets }\end{array}$} & \multicolumn{6}{|c|}{ Averaged rates of erosion and accretion } \\
\hline & \multicolumn{3}{|c|}{ North Core Banks } & \multicolumn{3}{|c|}{ South Core Banks } \\
\hline & $\begin{array}{c}\text { Average } \\
\text { (ft/yr) }\end{array}$ & $\begin{array}{c}\text { Maximum } \\
\text { erosion } \\
\text { (ft/yr) }\end{array}$ & $\begin{array}{c}\text { Maximum } \\
\text { accretion } \\
\text { (ft/yr) }\end{array}$ & $\begin{array}{c}\text { Average } \\
\text { (ft/yr) }\end{array}$ & $\begin{array}{c}\text { Maximum } \\
\text { erosion } \\
\text { (ft/yr) }\end{array}$ & $\begin{array}{c}\text { Maximum } \\
\text { accretion } \\
\text { (ft/yr) }\end{array}$ \\
\hline USACE $1960-61^{1}$ & -65 & -164 & +60 & -23 & -88 & +112 \\
\hline USACE $1961-62^{1}$ & -36 & -226 & +153 & -17 & -146 & +120 \\
\hline USACE 1960-62 & -52 & -125 & +123 & -21 & -80 & +45 \\
\hline G\&G 1962-71 & +20 & +5 & +55 & +4 & -11 & +36 \\
\hline ECU 1960-2001 & -8 & -19 & -1 & -3 & -9 & -1 \\
\hline NCDCM 1946-98 & -5 & -12 & $<-2$ & -5 & -30 & $<-2$ \\
\hline
\end{tabular}

${ }^{1}$ The extremely high erosion and accretion numbers associated with the opening, migration, and closing of inlets on North Core Banks resulting from the two storms have been eliminated from this analysis (i.e., profiles P44, P45, P62, P66, P67, and P68). 


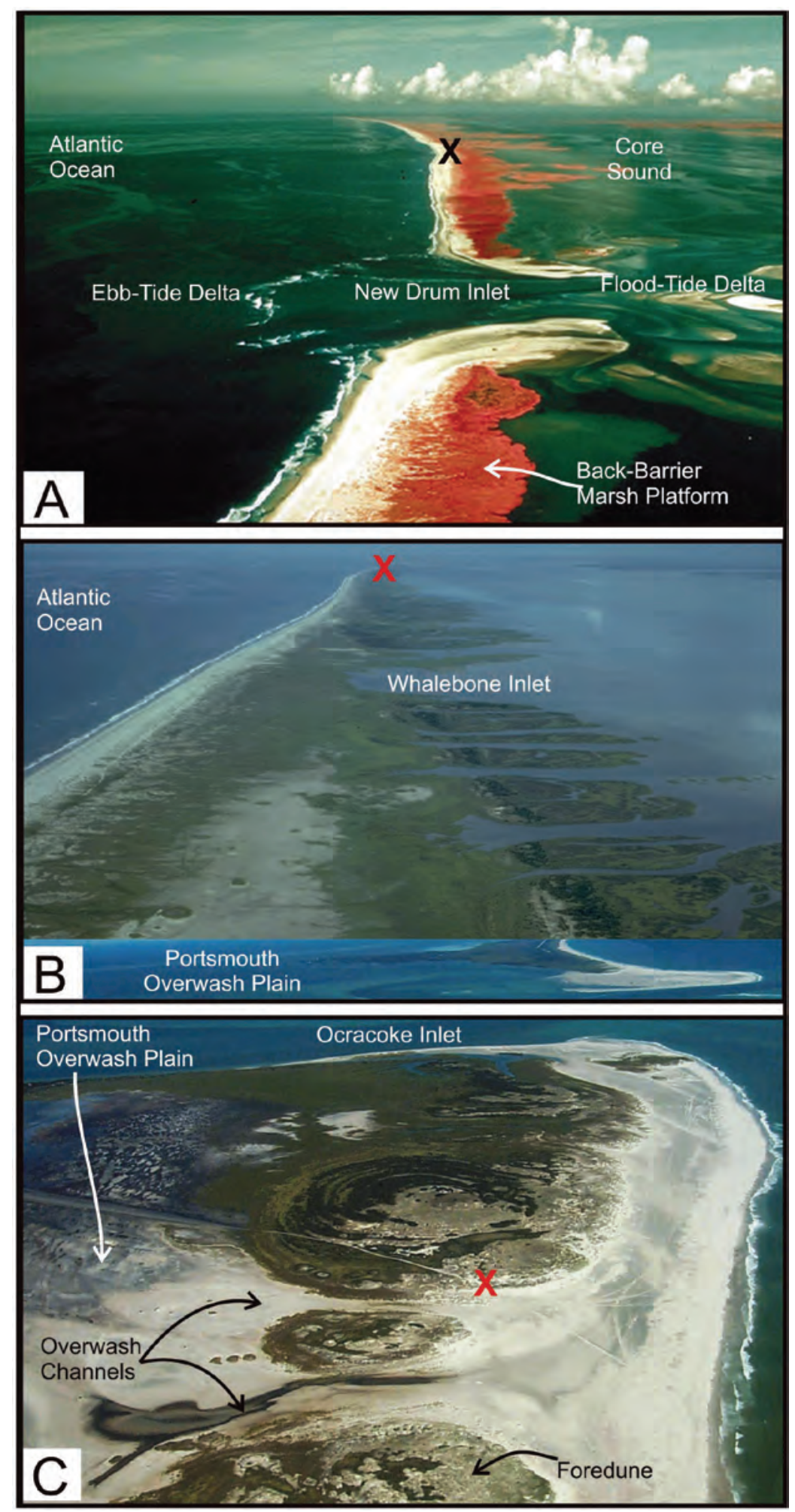

Figure 24. Specific features that are relevant to the dynamics of shoreline change, Core Banks, Cape Lookout National Seashore, North Carolina. (A) This false-color infrared aerial photograph was taken in 1977 looking southwest at New Drum Inlet, which separates North Core Banks from South Core Banks. Notice the significant bend in the shoreline a few miles beyond New Drum Inlet. This bend is an island segment that has experienced very low rates of shoreline change through time and probably reflects the interaction of the underlying geologic framework and shoreface composition. Photograph is by Duncan Heron of Duke University. $(B)$ This aerial photograph was taken in 1977 looking southwest at the end of the Portsmouth Overwash Plain, which has been terminated by the ephemeral Whalebone Inlet. Notice the bend in the shoreline just beyond Whalebone Inlet where the back-barrier marsh platform peat is cropping out on the shoreface. This is a segment of shoreline with low erosion rates that are probably due to the presence of underlying peat deposits in the shoreface. Photograph is by Duncan Heron of Duke University. (C) This aerial photograph was taken in 2001 looking northeast at the same area marked by an X in Figure 3 (1940, 1962, and 1983). Notice how high and wide the foredune complex and how extensive the vegetation have become through time on both the dunes and associated overwash plain. This sand accretion has deeply buried the reference markers in the dunes and associated overwash plain. Photograph is by William Birkemeier of the USACE Field Research Facility. 
in 1999 as New-Old Drum Inlet (fig. 2). However, because all reference markers for profiles P34 through P41 were apparently eroded, it is impossible to reconstruct the details of inlet change. Based on the NCDCM long-term data sets, the areas near P34-P42 (fig. 23) show high average annual rates of erosion, with rates up to $-17 \mathrm{ft} / \mathrm{yr}$. At P39 (fig. 23), the average annual erosion rate was calculated from the NCDCM 1946-1998 data set to be $-30 \mathrm{ft} / \mathrm{yr}$, in direct response to the migration of the New Drum Inlet channel. Also, the large net accretion $(+153 \mathrm{ft} / \mathrm{yr})$ mapped at P45 by the USACE 1962 survey (fig. 18) resulted from the southwestern migration of the Old Drum Inlet channel and associated spit (fig. 2), which was in direct response to the 1962 Ash Wednesday nor' easter storm (USACE, 1964).

\section{Elevation Changes on Core Banks Through Time}

The original ground elevation at each USACE reference marker, as surveyed during the 1961 survey, is shown in column D (appendix 1). In 1970, Godfrey and Godfrey (1976) located 141 reference markers (36 RM-0, 46 RM-1, and 59 RM-2) along 69 of the original USACE profiles (table 3 ). Of the 90 missing markers, 53 percent were those closest to the ocean (RM-0), and 23 percent were $200 \mathrm{ft}$ from the ocean (RM-2). Of those recovered, 107 showed an accretion of sediment, with the number of markers and the amount of accretion increasing away from the ocean. The remaining 34 markers showed deflation, which was greatest nearest the ocean. The actual ground elevation changes were small, with average elevations of $+6.7 \mathrm{ft}$ for RM-0s, $+6.4 \mathrm{ft}$ for RM- $1 \mathrm{~s}$, and $+6.1 \mathrm{ft}$ for RM-2s, as compared to the original USACE 1961 elevations (table 6).

The ECU 2001 survey located 83 reference markers (15 RM-0s, 33 RM-1s, and 35 RM-2s) along 57 of the original USACE profiles (table 4). Of the 148 missing markers, 81 percent were those closest to the ocean (RM-0), and 55 percent were farthest from the ocean (RM-2). In addition, 17 RM-4 through RM-8 markers also were located for a total of 100 (38 percent) of the 264 original USACE reference markers. Of all reference markers recovered, 100 percent either demonstrated no change since 1961 or accreted sediment. The average ground elevation for all recovered markers was $+10.1 \mathrm{ft}$ for RM-0s, $+9.1 \mathrm{ft}$ for RM-1s, and $+8.5 \mathrm{ft}$ for RM-2s, as compared to the original USACE 1961 elevations (table 6).

Because so many reference markers have been lost to shoreline erosion through time, only a general pattern of elevation change can be determined. The average ground elevations at the recovered RM-0, RM-1, and RM-2 sites in the G\&G 1970 and ECU 2001 surveys, relative to the USACE 1961 ground elevation, are compared in figure 25 and table 6. The increase in ground elevation is approximately 26 percent from 1961 to 1970 and approximately 41 percent from 1970 to 2001 . The net increase in island elevation from the
1961 survey to the 2001 survey resulted in approximately a 72-percent increase in island elevation through time.

The result of numerous storms is not only the systematic recession of the shoreline, but also major overwash events that move sand onto and across the island; this process is critical for island building and migration. This substantial increase in elevation is hypothesized to reflect the vertical accretion resulting from the deposition of frequent storm-driven, crossisland overwash fans through time. This can only happen on an undeveloped barrier island with a general absence of constructed barrier dune ridges, maintained roads, and structural developments along the oceanfront.

The berm crest and associated dunes are the highest point on an overwash-dominated barrier island with a gradual slope down the overwash plain to the estuary (fig. 20). As shoreline recession proceeded, the high berm crest migrated further landward on the barrier island, eroding many of the RM-0s. As the berm crest migrated, overwash processes moved sand across the island as overwash fans. This systematically added elevation to the back barrier and buried the remaining RM-1 and RM-2 markers (fig. 10). Most recovered reference markers were buried by either dune sands or overwash fans. This resulted in a general increase in island elevation further inland through time, as shown in the schematic cross sections in figure 10 .

The elevation change data (table 6) supports another major change in the character of Core Banks through time. Aerial photographic time-slice analysis suggests that Core Banks is no longer dominated by the high frequency of overwash processes that apparently occurred during the pre1963 period. Time-slice analysis of Core Banks from 1940 to 1998 shows an increase in vegetative growth during the post1970 period (White and Riggs, 2002; White and others, 2002; Ames and others, 2003). Higher island elevations resulting from increased overwash deposition through time would eventually decrease the vulnerability to overwash and initiate increased vegetative growth on Core Banks. The time-slice analysis in figure 26 strongly suggests that at least up to the Ash Wednesday storm in 1962, overwash was the dominant process. Then, with the increase in major storm activity during the 1971-2001 period, a few extensive overwash events (e.g., Hurricane Gordon in 1994 and Hurricane Isabel in 2003) substantially increased the average elevation of Core Banks and led to further increases in the amount of vegetation.

A five-part, aerial photograph, time-slice sequence of the Swash Inlet to Whalebone Inlet segment of North Core Banks is shown in figure 26. The 1940, 1943, and 1962 aerial photographs show overwash-dominated barrier islands with only minor levels of vegetative growth that are restricted to an older intertidal sequence of back-barrier platform marshes with extensive active subaerial and submerged sand bodies. The 1983 and 1998 aerial photographs show increasing amounts of subaerial, intertidal, and submerged aquatic vegetation with diminishing amounts of both subaerial and submerged bare sand. The 1983 time slice shows the transition stage from the 1940 to 1962 low, slightly vegetated, and 
Table 6. Summary of net ground elevation and percent change data for all reference markers from surveys by the U.S. Army Corps of Engineers, Godfrey and Godfrey, and East Carolina University for Core Banks, Cape Lookout National Seashore, North Carolina.

[Data are shown for the original 231 RM-0s, RM-1s, and RM-2s installed by the U.S. Army Corps of Engineers (USACE) along 77 profiles in 1961, the 141 reference markers located by the Godfrey and Godfrey (G\&G) 1970 survey, and the 83 reference markers located by the East Carolina University (ECU) 2001 survey. All elevations are in relation to mean sea level (1929 datum). ft, feet]

\begin{tabular}{|c|c|c|c|c|}
\hline Reference markers & RM-Os & RM-1s & RM-2s & ALL RMs ${ }^{1}$ \\
\hline USACE 1961 Average ground elevation (in feet) & +5.8 & +5.2 & +4.8 & +5.0 \\
\hline 1961 to 1970 Percent increase in elevation & 16 & 23 & 27 & 26 \\
\hline G\&G 1970 Average ground elevation (in feet) & +6.7 & +6.4 & +6.1 & +6.1 \\
\hline 1970 to 2001 Percent increase in elevation & 51 & 42 & 39 & 41 \\
\hline 1961 to 2001 Percent increase in elevation & 74 & 75 & 77 & 72 \\
\hline
\end{tabular}

'Includes all reference markers from RM-0 through RM-2 plus all others through RM-8 that were established by the USACE in 1961 (total RMs = 264) and located by the G\&G 1970 and ECU 2001 surveys (see appendixes 1, 3, and 6).

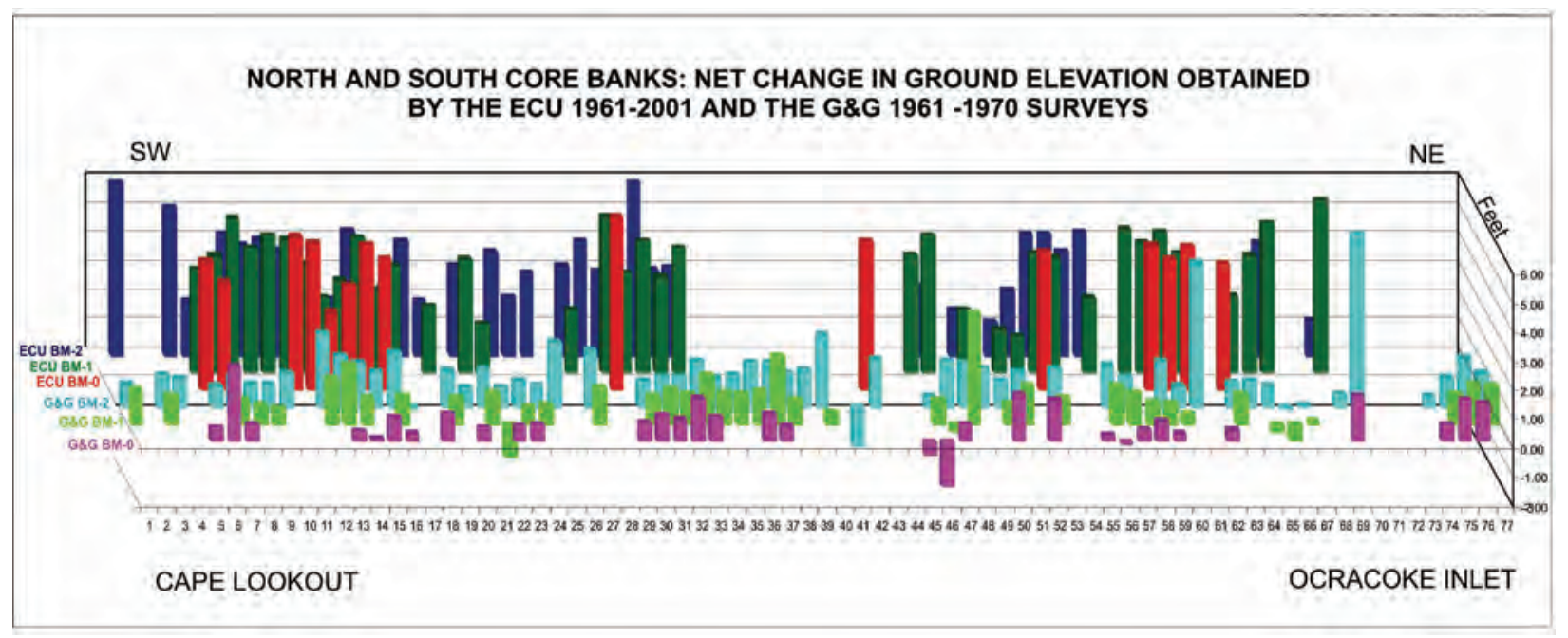

Figure 25. Elevation changes measured by the Godfrey and Godfrey 1970 and East Carolina University 2001 surveys as compared to the U.S. Army Corps of Engineers survey when the reference markers were installed on 77 profiles, Core Banks, Cape Lookout National Seashore, North Carolina. The G\&G survey located 141 reference markers along 69 profiles and the ECU survey located 83 reference markers along 57 profiles.

overwash-dominated character of Core Banks to the post1971 period of increasing elevation with the resultant increase in vegetative growth that is beginning to take over in the subaerial and submerged aquatic habitats. The 1998 time slice shows that most of the subaerial and intertidal habitats are heavily vegetated, with subaerial vegetation on the overwash plain and marsh vegetation on the intertidal marsh platforms. Approximately half of the submerged sand shoal habitat contains a dense growth of submerged aquatic vegetation (very dark color) in the lower swales between the higher sand shoals (light tan) that are semi-stabilized by micro-algal mats.
Today, Core Banks is modestly vegetated, and overwash occurs during some of the larger storm events such as Hurricane Isabel (fig. 2D). The data presented in this report suggest that the increased vegetation has taken place in direct response to storm activity and the associated overwash that has substantially increased island elevation since the 1961 USACE survey. It is also possible, however, that the changes in vegetation were partially in response to a change in climate, sea level, human modification, NPS management policies, or some combination thereof (fig. 27). 


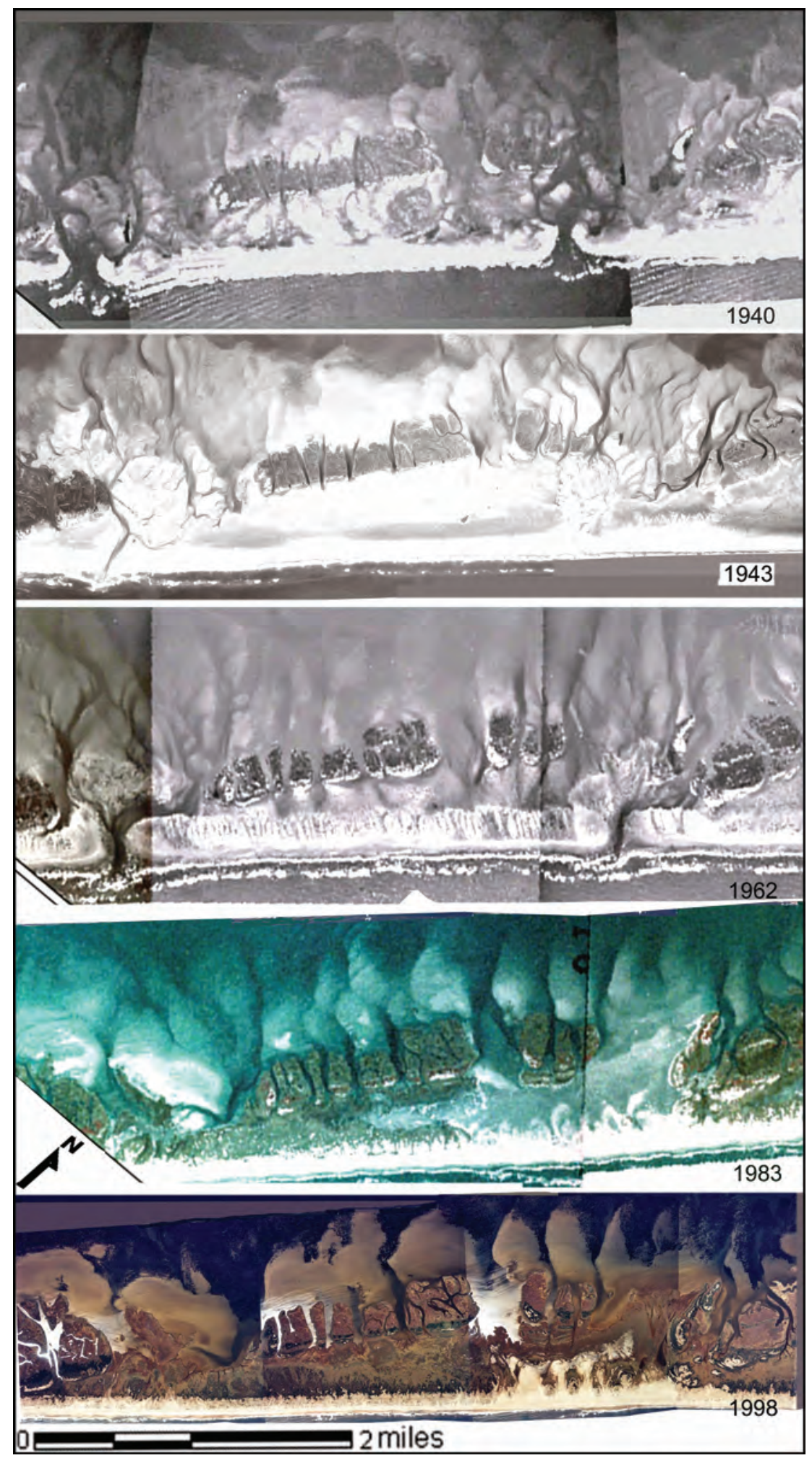

Figure 26. A five-part, aerial photograph, time-slice sequence showing the Swash Inlet to Whalebone Inlet segment of North Core Banks, Cape Lookout National Seashore, North Carolina. The 1940, 1943, and 1962 aerial photographs contain minor levels of vegetative cover that are restricted to an older intertidal sequence of back-barrier platform marshes with extensive active subaerial and submerged sand bodies. The 1983 and 1998 aerial photographs show increasing amounts of subaerial, intertidal, and submerged aquatic vegetation with diminishing amounts of both subaerial and submerged bare sand. (Panel 1940) Swash Inlet (left) and Whalebone Inlet (right) reopened sometime prior to 1940 (around 1939 according to Fisher, 1962 and Payne, 1985) and were active, but ephemeral inlets through 1962 in an early stage of building back-barrier floodtide deltas. (Panel 1943) Major overwash has occurred, the flood-tide deltas are almost totally sanded in with many minor channels (late-stage development), and both inlets are barely open. (Panel 1962) The Ash Wednesday nor'easter resulted in major overwash fans across the berm crest, the inlet channels have been reopened in the more southerly location, and the flood-tide delta sand lobes have been spread out and re-channeled. (Panel 1983) This time slice shows the transition stage from the 1940 to 1962 low, slightly vegetated, and overwashdominated character of Core Banks to the post1971 period of increasing island elevation, with the resultant increase in vegetative cover that is beginning to take over in the subaerial and submerged aquatic habitats. (Panel 1998) Most of the subaerial and intertidal habitats are heavily vegetated, with subaerial vegetation on the overwash plain and marsh vegetation on the intertidal marsh platforms. Approximately half of the submerged sand shoal habitat now contains a dense growth of submerged aquatic vegetation (very dark color) in the lower swales between the higher sand shoals (light tan) that are semi-stabilized by micro-algal mats. 

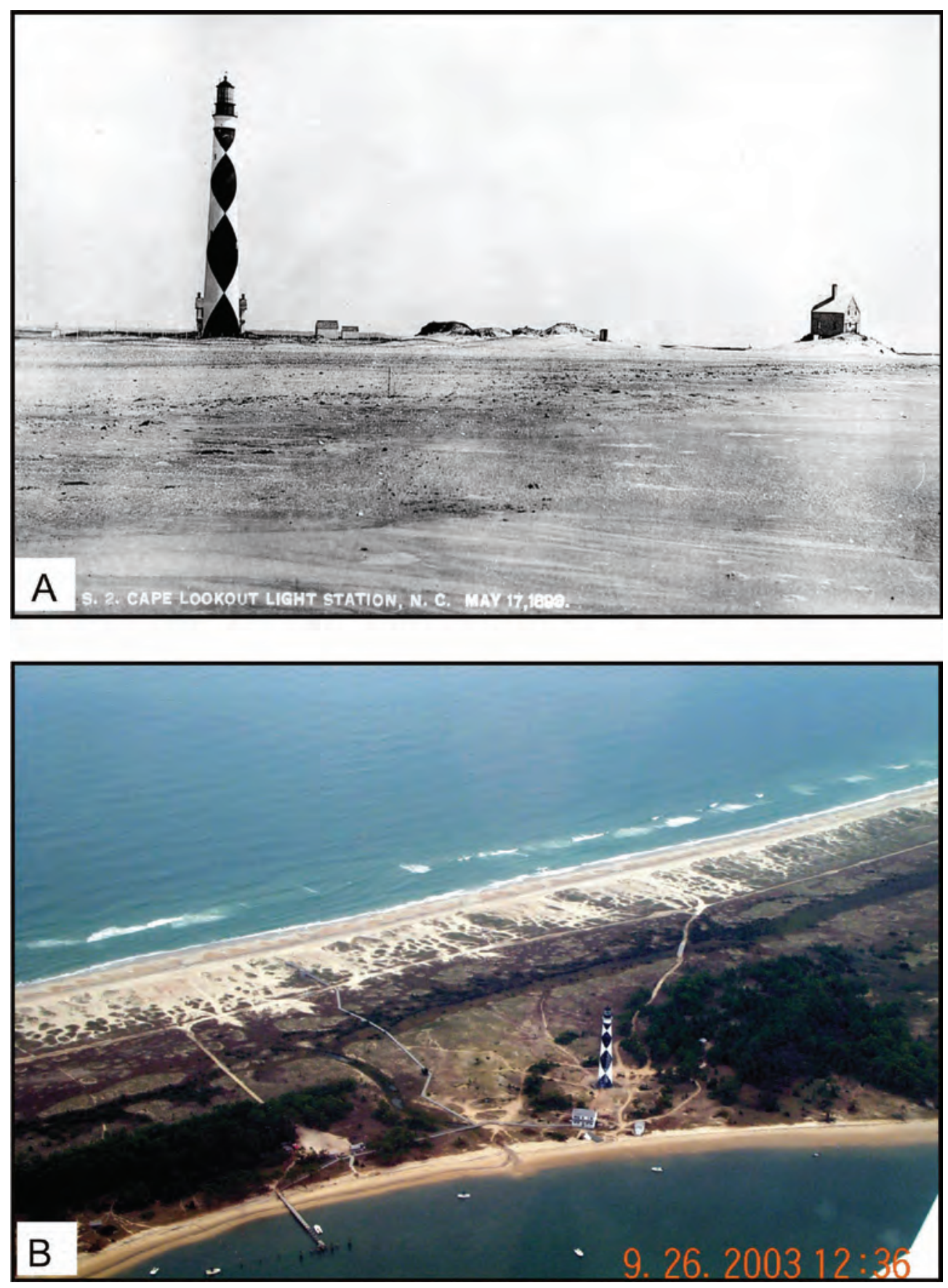

Figure 27. Changes with time on Core Banks, Cape Lookout National Seashore, North Carolina. (A) A 1898 ground photograph on South Core Banks, looking west from the beach towards the Cape Lookout Lighthouse and the estuarine shoreline. The lighthouse is situated on the estuarine side of an extensive overwash plain. Notice the very low, flat, and poorly vegetated character of the overwash plain. Photograph is from the Cape Lookout National Seashore. (B) A 2003 oblique aerial photograph shows the same area taken from the estuarine side looking towards the southeast across the overwash plain. Notice that the plain is heavily grassed with Spartina patens. The pine trees (dark green patches) were planted in the 1950s and 1960s. Photograph is by 0.H. Pilkey of Duke University. 


\section{Summary and Conclusions}

A research program to study the origin and evolution of North Carolina's coastal system was begun in 2000 as a cooperative effort between the U.S. Geological Survey (USGS), East Carolina University (ECU), and the North Carolina Geological Survey (NCGS). A primary goal of the program was to investigate the roles that the underlying geologic framework, climate change, and sea-level fluctuation play in the dynamics of short-term coastal behavior and long-term coastal evolution. Concurrent programs by the National Park Service (NPS) to develop a Geologic Resources Inventory for the Cape Hatteras and Cape Lookout National Seashores brought the groups together. One objective of the combined program was to evaluate barrier island dynamics along a natural section of the North Carolina coast known as Core Banks during a 41-year time period (1960-2001). This barrier island segment includes North and South Core Banks, extends for 51 miles from Ocracoke Inlet to Cape Lookout, and is part of Cape Lookout National Seashore.

Shoreline changes were evaluated by comparing the results of four surveys previously conducted along Core Banks with a 2001 survey by East Carolina University. The first survey was done by the U.S. Army Corps of Engineers (USACE), who installed and surveyed 77 profiles and associated reference markers in June 1960 between Cape Lookout and Ocracoke Inlet. On September 12, 1960, Hurricane Donna destroyed many of the surveyed reference markers. From September to December of 1961, the USACE replaced the destroyed reference markers and resurveyed all control points, including a survey of estuarine and nearshore bathymetry associated with specific profiles. Another storm, the Ash Wednesday nor'easter of March 7-9, 1962, destroyed many of the reference markers again. Consequently, the USACE replaced the destroyed reference markers and resurveyed the entire data set for the third time from June to July, 1962. Based on these surveys, the short-term average annual rate of shoreline erosion for all of Core Banks during this storm-dominated period was - 40 feet per year (ft/yr) for 1960-1961 and -26 ft/yr for 1961-1962, with ranges from $-226 \mathrm{feet}(\mathrm{ft})$ to $+153 \mathrm{ft}$ at specific locations. The combined (1960-1962) short-term rate of shoreline erosion was -36 ft/yr.

In 1970, Godfrey and Godfrey (G\&G) located and measured ground elevations on one or more of the USACE reference markers along 55 of the original 77 profiles. In the summer of 1971, after 9 years of minimal storm activity, G\&G surveyed the shoreline change from reference markers along 39 of the original USACE profiles. The short-term (9 year), non-stormy period was characterized by net shoreline accretion. Based on the G\&G survey, the average annual rate of accretion for all of Core Banks from 1962-1971 was +12 $\mathrm{ft} / \mathrm{yr}$, with ranges from $-11 \mathrm{ft} / \mathrm{yr}$ to $+55 \mathrm{ft} / \mathrm{yr}$. The maximum accretion recorded during the low-storm period of the G\&G survey was at the two ends of Core Banks, directly adjacent to Cape Lookout and Ocracoke Inlet, where average annual accretion rates were $+36 \mathrm{ft} / \mathrm{yr}$ and $+55 \mathrm{ft} / \mathrm{yr}$, respectively.

On September 30 to October 1, 1971, Hurricane Ginger came ashore to begin a 19-year period (1971-1990) of moderate storm activity. This was followed by an 13-year period that represented the most active storm period in recorded North Carolina history (1991-2005). During the summer of 2001, personnel from ECU, along with personnel from Cape Lookout National Seashore, located and resurveyed reference markers on 57 of the original 77 USACE profiles. The ECU 2001 survey used the initial USACE 1960 survey data to obtain an average annual long-term (41 years) shoreline erosion rate for all of Core Banks. The 1960-2001 (ECU) data resulted in an average annual shoreline recession rate of -5 $\mathrm{ft} / \mathrm{yr}$, with ranges from $-19 \mathrm{ft} / \mathrm{yr}$ to $0 \mathrm{ft} / \mathrm{yr}$. The highest erosion rates were midway between Whalebone Inlet and Portsmouth Village. The ECU 1960-2001 survey data were compared to the long-term (1946-1998) shoreline erosion data of North Carolina Division of Coastal Management (NCDCM) that were derived using different methods. The NCDCM (52-year) data resulted in an average annual shoreline recession rate of $-5 \mathrm{ft} / \mathrm{yr}$ for all of Core Banks, which is the same long-term rate as the ECU long-term data set.

Shoreline change data of the USACE, G\&G, and ECU surveys were compared for North and South Core Banks through time. North Core Banks had substantially higher average annual rates of erosion and accretion compared to South Core Banks. Data from the USACE survey (1960-1962) showed erosion rates of $-52 \mathrm{ft} / \mathrm{yr}$ for North Core Banks compared to $-21 \mathrm{ft} / \mathrm{yr}$ for South Core Banks. Data from the G\&G survey (1962-1971) showed accretion rates of $+20 \mathrm{ft} / \mathrm{yr}$ for North Core Banks compared to $+4 \mathrm{ft} / \mathrm{yr}$ for South Core Banks. Data from the ECU survey (1960-2001) showed erosion rates of $-8 \mathrm{ft} / \mathrm{yr}$ for North Core Banks compared to $-3 \mathrm{ft} / \mathrm{yr}$ for South Core Banks.

By 1962, the USACE had installed a total of 264 reference markers identified as RM- 0 on the oceanside and RM-2 on the inland side along all 77 profiles between Cape Lookout and Ocracoke Inlet. They also installed RM-4, RM-6, and RM-8 markers on a few profiles in wider island segments. Of the 231 reference markers installed in the RM-0, RM-1, and RM-2 series, the G\&G 1970 survey recovered a total of 141 reference markers (61 percent); however, only 36 (47 percent) of the 77 oceanside RM-0s were recovered. The ECU 2001 survey recovered a total of 83 reference markers (36 percent); however, only 15 (19 percent) of the original 77 oceanside RM-0s were recovered.

Changes in ground elevation were determined by measuring the amount of accretion or erosion of sediment on each reference marker relative to the ground elevation measured by the 1961 USACE survey. The average increase in ground elevation from the USACE 1961 survey to the G\&G 1970 survey was: $\mathrm{RM}-0=+0.9 \mathrm{ft}, \mathrm{RM}-1=+1.2 \mathrm{ft}$, and $\mathrm{RM}-2=$ $+1.3 \mathrm{ft}$. In comparison, the average increase in ground elevation from the USACE 1961 survey to the ECU 2001 survey was $\mathrm{RM}-0=+4.3 \mathrm{ft}, \mathrm{RM}-1=+3.9 \mathrm{ft}$, and $\mathrm{RM}-2=+3.7 \mathrm{ft}$. 
The ECU survey represents approximately a 72-percent net increase in barrier island elevation during the 40-year period, with all recovered reference markers displaying either major sediment accretion or little to no change.

The period of low storm activity (1962-1970) was characterized by minimal overwash events with minor vertical accretion; however, during the period of moderate to high storm activity (1971-2005), frequent overwash events led to a major increase in island elevation. This increased elevation led to a major increase in vegetative growth throughout most of the barrier island ecosystems. Thus, the processes of storm overwash are important in maintaining and building island elevation when allowed to occur unhindered.

As expected, the greatest amounts of both erosion and accretion occurred in direct association with individual storms and the resulting inlet dynamics during the USACE 1960-1962 surveys. Shoreline recession up to $-260 \mathrm{ft}$ and accretion up to $+525 \mathrm{ft}$ occurred in direct response to either the opening, closing, or lateral migration of the channel and spit associated with Old Drum, New Drum, and New-Old Drum Inlets, as well as the periodic opening and closing of the more ephemeral Whalebone and Swash Inlets.

Based on the USACE original bathymetric survey to 30-ft water depths, offshore slope geometry may reflect, and possibly even be responsible for the dynamics occurring on the adjacent barrier island segment. The lowest slope occurs along profiles adjacent to Cape Lookout and adjacent to Ocracoke Inlet. Between these two end points, the slope increases to its steepest point just southwest of New Drum Inlet. This is approximately where a significant bend occurs in South Core Banks and also the area where the 6- and 12-ft bathymetric contours have the greatest slopes, suggesting that some sort of indurated stratigraphic units may be controlling the substrate geometry. Further study is needed to investigate the development and changes of the ocean shoreline and its role in affecting the island.

The storm type (tropical storms, hurricanes, nor'easters), the directional path of the storm relative to the coastal system, and the frequency and pattern of successive storm events, can produce different erosion and accretion patterns along any given shoreline. Integrating the USACE, G\&G, ECU, NCDCM shoreline erosion surveys for Core Banks demonstrate these important points about shoreline recession.

1. The ECU and NCDCM data sets demonstrate that there is an ongoing net, long-term, but small-scale shoreline recession associated with the North Carolina barrier islands.

2. The USACE and G\&G short-term data sets demonstrate that processes associated with individual storm events or sets of events, as well as the absence of events, can produce extremely large-scale changes that include both erosion and accretion, respectively.

3. The short-term, non-stormy period data set of G\&G demonstrates that if given enough time between storm events, barriers can rebuild to their pre-storm period conditions. However, the post-storm shoreline response rarely gets there before the next storm or stormy period sets in.
4. The result is a net long-term change documented by the ECU 1960-2001 and NCDCM 1946-1998 Core Banks data sets that resulted in net annual average erosion rates of $-5 \mathrm{ft} / \mathrm{yr}$.

5. This results in a long-term net recession that is of a substantially smaller scale than that of individual storm events. In other words, the shoreline tends to develop a net response similar to the "two steps forward and one step backward" scenario.

6. Thus, long-term, small-scale shoreline erosion data are an average that does not reflect the impact of storm events. To more accurately reflect shoreline dynamics, erosion data should include ranges of maximum and minimum change.

7. Long-term survey data demonstrate a general increase in island width, elevation, and consequent vegetation on Core Banks over the past four decades. Aerial photographic timeslice analysis corroborates the survey data.

A. Aerial photographic evidence suggests that the islands were dominated by active overwash processes during the very stormy pre-1963 history, as indicated by vast areas of nonvegetated sand flats and fan deltas containing well-developed and active drainage systems across the barrier islands. During this stormy period, the overwash processes were actively building island width. The drainage systems flowed off the overwash plains and through major overwash tidal channels that occurred between extensive estuarine platform marshes. Where the tidal channels discharged into the estuary, major fan deltas formed.

B. Survey data, field mapping, and aerial photographic evidence demonstrate that the post-1963 period has been dominated by increasing island elevation through time. The increased elevation has in turn led to a decrease in the frequency and extent of overwash events and an increase in the growth of vegetation through time. The decrease in overwash events allowed the submerged fan-delta lobes to become stabilized by submerged aquatic vegetation and algae, while the intertidal portion of the fan-deltas evolved into low marshes. The post-1963 overwash plains formed stair-stepped ramps- the lower zone evolved into high marshes, the intermediate zone developed shrub-scrub communities, and the upper, oceanward part of the overwash ramp became dominated by scattered, ephemeral dune fields.

C. These results indicate that the back-barrier environments of Core Banks have experienced a substantial increase in marsh wetlands and growth of submerged aquatic vegetation over the past four decades in response to natural barrier island evolutionary processes. This is a critical finding in light of the fact that most estuarine shorelines in North Carolina that are dominated by wetland marshes are experiencing severe shoreline erosion and wetland loss. 
This study provides a basis for comparison of the effects of barrier island dynamics on a coastal system that is fairly natural and only slightly modified-Cape Lookout National Seashore-with an adjacent coastal system that has been modified by human influences - Cape Hatteras National Seashore. The re-evaluation of USACE and G\&G survey data on Core Banks, together with the ECU survey, represents an important component in understanding the dynamics of high energy, barrier island systems. It is imperative that the natural processes and responses driving the evolution of barrier islands be understood for the longterm management of these dynamic coastal systems in light of global climate change and sea level rise. The design and implementation of appropriate management plans is crucial for Cape Lookout and Cape Hatteras National Seashores, as well as other seashores in the National Park Service system and the future of our valuable coastal resources.

\section{Acknowledgments}

This manuscript is a product of the North Carolina Coastal Geology Cooperative Program, a 7-year, multi-institutional effort of East Carolina University (ECU), the U.S. Geological Survey (USGS), and North Carolina Geological Survey (NCGS). Primary funding is through the USGS Coastal and Marine Geology Program (Woods Hole, Mass.) Cooperative Agreements 01ERAG0010 and 02ERAG0044. Supplementary support is from the U.S. National Park Service (P521001A704), U.S. Fish and Wildlife Service (1448-40181-02-G-082), Environmental Defense, and East Carolina University.

Special thanks are extended to the following who personally dedicated a significant amount of time and effort to this project on Core Banks. Dr. Michael Rikard, Resource Management Specialist, and Jeff Cordes, Biologist at Cape Lookout National Seashore, provided extensive help with the field logistics of working on Core Banks and with locating the U.S. Army Corps of Engineers (USACE) survey markers. Robert White, research technician at ECU, was responsible for locating and surveying the $\mathrm{x}, \mathrm{y}$, and $\mathrm{z}$ location of all USACE reference markers recovered during the ECU 2001 survey. Ronald Crowson, geologist for Geo Solutions
Limited Inc., provided ground-penetrating radar survey equipment and operating time to help run the surveys on Core Banks. David Nichols and Barry Erwin, boat operators and seismic technicians for the USGS, provided their services and equipment to run the high-resolution seismic profiles in Core Sound. James Watson, research technician and boat captain in the ECU Geology Department, provided many months of hard work on the North Carolina waterways and critical expertise in equipment operation and maintenance through many years of field research. Greg Williams, Lynn Jack, and Tom Jarrett (formerly) of the USACE, Wilmington District Office, were helpful in recovering old survey data and supplying aerial photographs.

Personal thanks go to the faculty, staff, and students of the Geology Department at ECU, who carried out various supporting studies during 2000-2007 on barrier island dynamics and helped develop the scientific understanding of this complex system. The authors have participated in an extensive research program concerning the origin and evolution of the North Carolina estuarine system for the late Pleistocene and Holocene (the last 20,000 years of earth history). This program has included the following faculty researchers whose work has added greatly to our overall understanding of coastal dynamics: Dr. Stephen J. Culver, Dr. David J. Mallinson, Dr. D. Reide Corbett, and Dr. J.P. Walsh of ECU; Mr. Charles W. Hoffman and Dr. Kathleen Farrell of the North Carolina Geological Survey; Dr. E. Robert Thieler, David Foster, and Erika Hammar-Klose of the U.S. Geological Survey; Dr. John Wehmiller of the University of Delaware; and Dr. Jesse McNinch of Virginia Institute of Marine Science. The never-ending hard work of the following ECU graduate students is greatly acknowledged: K.E. Burdette, C.A. Grand Pre, M.Hale, J. Jomp, P.R. Parham, M.P. Ricardo, J. Rosenberger, M. Sims, C.G. Smith, and D. Twamley. Many other faculty, staff, students, individuals, and agencies supplied key support, information, and resources over the years that have allowed this long-term project to succeed-we extend our greatest thanks to all of you. 


\section{References Cited}

Ames, D.A., Riggs, S.R., and White, R.M., 2003, Time-slice analysis of geomorphic-Ecologic systems and decadalscale barrier island evolution, North Carolina Outer Banks: Geological Society of America Abstracts with Programs, v. 35 , no. 6 , paper $18-11$.

Barnes, J., 2001, North Carolina's hurricane history (3d ed.): Chapel Hill, N.C., University of North Carolina Press, 319 p.

Benton, S.B., Bellis, C.J., Overton, M.F., Fisher, J.S., Hench, J.L., and Dolan, R., 1993, North Carolina long term annual rates of shoreline change: North Carolina Division of Coastal Management Publication, 16 p. and 17 maps.

Benton, S.B., Bellis, C.J., Overton, M.F., Fisher, J.S., Hench, J.L., and Dolan, R., 1997, North Carolina long term annual rate of shoreline change-Methods report, 1992 update: North Carolina Division of Coastal Management Publication, 60 maps.

Benton, S.B., Bellis, C.J., Knisel, J.M., Overton, M.F., Fisher, J.S., 2004, North Carolina 1998 long-term average annual erosion rate update-Methods report: North Carolina Division of Coastal Management, N.C. Coastal Resources Commission Information Item.

Cumming, W.P., 1966, North Carolina in maps: North Carolina Dept. of Archives and History, 36 p., +15 map reproductions.

Dolan, R., and Godfrey, P., 1973, Effects of Hurricane Ginger on the barrier islands of North Carolina: Geological Society of America Bulletin, v. 84, p. 1329-1334.

Fisher, J.J., 1962, Geomorphic expression of former inlets along the Outer Banks of North Carolina: Unpublished M.S. thesis, Dept. of Geology, University of North Carolina, Chapel Hill, 120 p.

Godfrey, P.J., and Godfrey, M.M., 1976, Barrier island ecology of Cape Lookout National Seashore and vicinity, North Carolina: National Park Service Monograph Series 9, 160 p.
Hayes, M.O., 1976, Terrigenous clastic depositional environments, in Hayes, M.O., and Kana, T.W., eds., A field course for the American Association of Petroleum Geologists: Univ. of South Carolina, Coastal Resources Division, Columbia, S.C., Technical Report 11-CRD, p. I-1 to I-131.

Holland, F.R., 1968, A survey history of Cape Lookout National Seashore: U.S. National Park Service, Division of History Publication, 50 p., plus plates.

Payne, R.L., 1985, Place names of the Outer Banks: Washington, N.C., Thomas A. Williams, Publisher, 198 p.

Riggs, S.R., and Ames, D.V., 2003, Drowning the North Carolina coast-Sea-level rise and estuarine dynamics: North Carolina Sea Grant College Publication UNC-SG-04-03, $153 \mathrm{p}$.

Savage, R.P., and Woodhouse, W.W., 1968, Creation and stabilization of coastal barrier dunes: 11th Conference on Coastal Engineering, Proceedings, p. 671-700.

Snyder, S.W., Hine, A.C., and Riggs, S.R., 1990, The seismic stratigraphic record of shifting Gulf Stream flow paths in response to Miocene glacioeustacy-Implications for phosphogenesis along the North Carolina continental margin, in Burnett, W.C., and Riggs, S.R., eds., Phosphate deposits of the world-Neogene to modern phosphates: Cambridge, England, Cambridge University Press, v. 3, p. 396-423.

Stick, D., 1958, The Outer Banks of North Carolina, 15841958: Chapel Hill, N.C., University of North Carolina Press, $352 \mathrm{p}$.

U.S. Army Corps of Engineers, 1964, Ocracoke Inlet to Beaufort Inlet, North Carolina-Combined hurricane survey interim report-Ocracoke Inlet to Beaufort Inlet, and beach erosion report on cooperative study of Ocracoke Inlet to Cape Lookout: Wilmington, N.C., U.S. Army Corps of Engineers, 28 p., plus 8 appendixes.

White, R.M., and Riggs, S.R., 2002, Coastal wetland formation since 1940_Core Banks, Cape Lookout National Seashore, NC: Raleigh, N.C., Water Resources Research Institute Annual Conference, Abstracts, p. 8.

White, R.M., Riggs, S.R., Mallinson, D.A., and Ames, D.V., 2002, Process-response, time-slice, geomorphic and ecologic mapping of Core Banks, Cape Lookout National Seashore, N.C.: Geological Society of America, Abstracts with Programs, v. 34, no. 6, paper 200-9. 



\section{Appendixes 1-7}

Appendix 1. Summary of the U.S. Army Corps of Engineers (USACE) data developed in the 1960, 1961, and 1962 surveys on Core Banks, Cape Lookout National Seashore, North Carolina. Data are summarized directly from the USACE report produced in 1964, and miscellaneous files and field notebooks located at the USACE Wilmington (N.C.) District Office

Appendix 2. Summary of the U.S. Army Corps of Engineers (USACE, 1964) 1961 survey data of the shoreface bathymetry for Core Banks, Cape Lookout National Seashore, North Carolina. The 1961 bathymetric survey data are the horizontal distances obtained along alternate profiles and measured from mean sea level shoreline, based upon the 1929 datum, out to the 6-, 12-, 18-, 24-, and 30-foot bathymetric contours, respectively

Appendix 3. Summary of the 1970 survey of Godfrey and Godfrey (1976) concerning change in surface elevation relative to the reference markers recovered on 69 of the 77 U.S. Army Corps of Engineers profiles established on Core Banks, Cape Lookout National Seashore, North Carolina. Because the actual survey data do not exist in the public domain, the data presented here are interpreted from a graph in figure 20 in Godfrey and Godfrey (1976).

Appendix 4. Summary of the 1971 Godfrey and Godfrey (1976) shoreline change survey data for 39 selected profiles of the 77 U.S. Army Corps of Engineers profiles established on Core Banks, Cape Lookout National Seashore, North Carolina. Because the survey data do not exist in the public domain, the data presented here are interpreted from a graph in figure 37 in Godfrey and Godfrey (1976).

Appendix 5. Latitude and longitude for the recovered U.S. Army Corps of Engineers (1964) reference markers and that were resurveyed in 2001 by East Carolina University for the present study on Core Banks, Cape Lookout National Seashore, North Carolina. The reference marker designations are as follows: 1-0 represents profile $\mathrm{P} 1$, and reference marker $\mathrm{RM}-0,2-2$ represents profile $\mathrm{P} 2$ and reference marker RM-2.

Appendix 6. Summary of the East Carolina University survey data developed for 57 of the 77 U.S. Army Corps of Engineers profiles located in the 2001 survey on Core Banks, Cape Lookout National Seashore, North Carolina.

Appendix 7. Summary of the North Carolina Division of Coastal Management (NCDCM) data for the average annual shoreline erosion rates on Core Banks, Cape Lookout National Seashore, North Carolina. The two data sets include the 1940 to 1992 period (Benton and others, 1993) and the 1946 to 1998 period (Benton and others, 1997). These data are plotted on a 1998 NCDCM aerial photograph mosaic for the entire North Carolina coast. NCDCM subdivided the coast into segments of similar erosion rates and labeled each segment with the average annual erosion rate. Refer to text for a description of the methodology. The 77 U.S. Army Corps of Engineers profiles for Core Banks were superimposed on the appropriate segments to obtain the NCDCM average annual erosion rate for each profile. 
Appendix 1. Summary of the U.S. Army Corps of Engineers (USACE) data developed in the 1960, 1961, and 1962 surveys on Core Banks, Cape Lookout National Seashore, North Carolina.

[ft, feet; MSL, mean sea level; --, no data; In 1960-1962, USACE constructed 77 profiles (P); each had 3 or more reference markers (RM) that were 100 ft apart and perpendicular to the shore. RM- 0 is closest to the ocean. The zero reference markers (RM-0) constitute the baseline. Profile 1 is located at Cape Lookout, profile 77 is located at Ocracoke Inlet. All profiles are 3,000 ft apart, except 1 and 2, and 76 and 77, which are 2,400 ft apart]

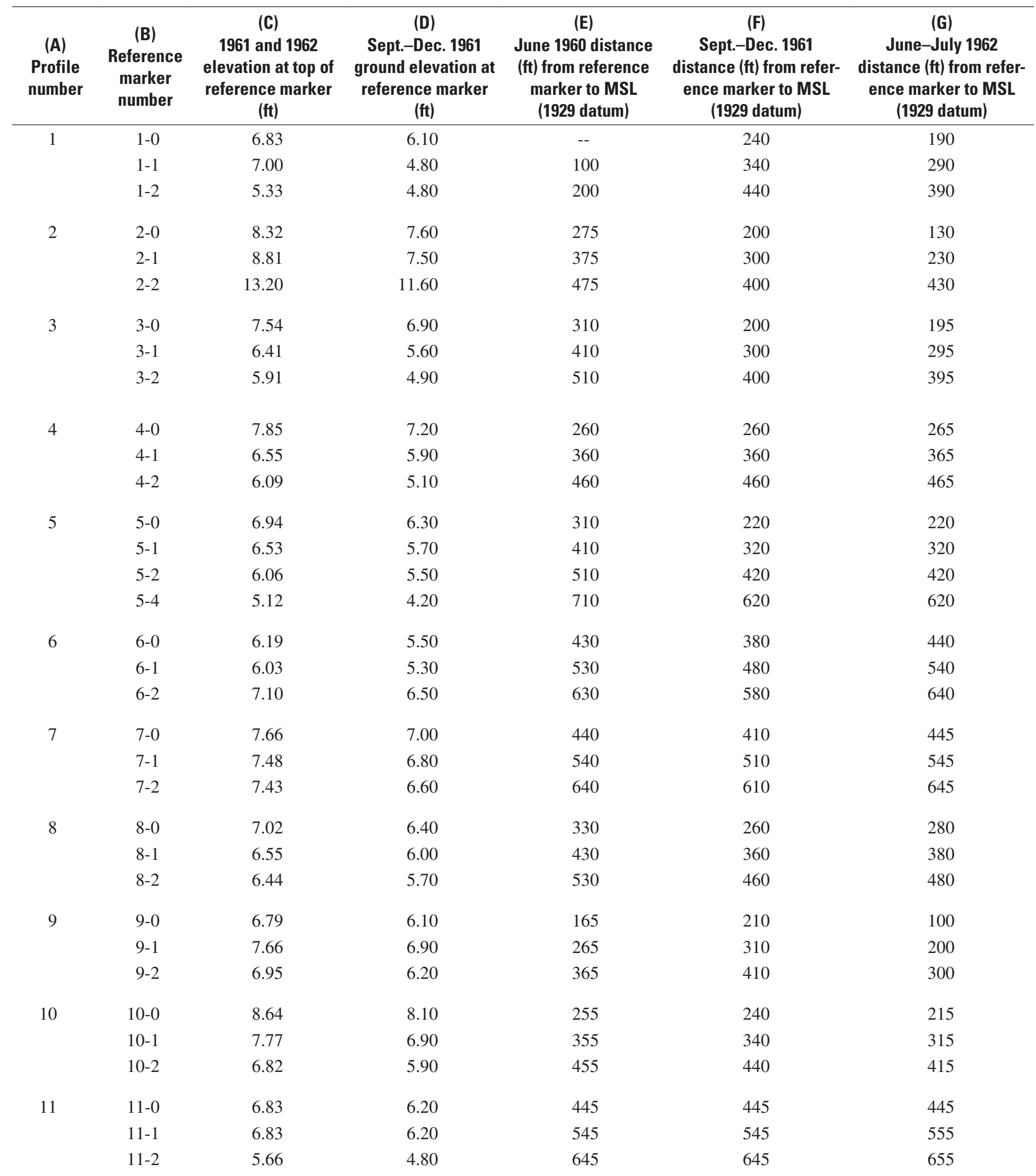


Appendix 1. Summary of the U.S. Army Corps of Engineers (USACE) data developed in the 1960, 1961, and 1962 surveys on Core Banks, Cape Lookout National Seashore, North Carolina.-Continued

[ft, feet; MSL, mean sea level; --, no data; In 1960-1962, USACE constructed 77 profiles (P); each had 3 or more reference markers (RM) that were 100 ft apart and perpendicular to the shore. RM-0 is closest to the ocean. The zero reference markers (RM-0) constitute the baseline. Profile 1 is located at Cape Lookout, profile 77 is located at Ocracoke Inlet. All profiles are 3,000 ft apart, except 1 and 2, and 76 and 77, which are 2,400 ft apart]

\begin{tabular}{|c|c|c|c|c|c|c|}
\hline $\begin{array}{c}\text { (A) } \\
\text { Profile } \\
\text { number }\end{array}$ & $\begin{array}{l}\text { (B) } \\
\text { Reference } \\
\text { marker } \\
\text { number }\end{array}$ & $\begin{array}{l}\text { (C) } \\
1961 \text { and } 1962 \\
\text { elevation at top of } \\
\text { reference marker } \\
\text { (ft) }\end{array}$ & $\begin{array}{l}\text { (D) } \\
\text { Sept--Dec. } 1961 \\
\text { ground elevation at } \\
\text { reference marker } \\
\text { (ft) }\end{array}$ & $\begin{array}{c}\text { (E) } \\
\text { June } 1960 \text { distance } \\
\text { (ft) from reference } \\
\text { marker to } \mathrm{MSL} \\
\text { (1929 datum) }\end{array}$ & $\begin{array}{c}\text { (F) } \\
\text { Sept.-Dec. } 1961 \\
\text { distance (ft) from refer- } \\
\text { ence marker to MSL } \\
\text { (1929 datum) }\end{array}$ & $\begin{array}{c}\text { (G) } \\
\text { June-July } 1962 \\
\text { distance (ft) from refer- } \\
\text { ence marker to MSL } \\
\text { (1929 datum) }\end{array}$ \\
\hline \multirow[t]{3}{*}{12} & $12-0$ & 7.19 & 6.70 & 390 & 380 & 380 \\
\hline & $12-1$ & 6.71 & 6.10 & 490 & 480 & 480 \\
\hline & $12-2$ & 6.70 & 6.00 & 590 & 580 & 580 \\
\hline \multirow[t]{3}{*}{13} & $13-0$ & 6.71 & 6.20 & 430 & 380 & 395 \\
\hline & $13-1$ & 6.23 & 5.60 & 530 & 480 & 495 \\
\hline & $13-2$ & 6.31 & 5.30 & 630 & 580 & 595 \\
\hline \multirow[t]{3}{*}{14} & $14-0$ & 6.16 & 5.60 & 490 & 385 & 415 \\
\hline & $14-1$ & 5.22 & 4.50 & 590 & 485 & 515 \\
\hline & $14-2$ & 4.69 & 3.90 & 690 & 585 & 615 \\
\hline \multirow[t]{3}{*}{15} & $15-0$ & 6.16 & 5.60 & 465 & 420 & 395 \\
\hline & $15-1$ & 5.42 & 4.70 & 565 & 520 & 495 \\
\hline & $15-2$ & 4.74 & 4.00 & 665 & 620 & 595 \\
\hline \multirow[t]{3}{*}{16} & $16-0$ & 7.07 & 6.20 & 465 & 500 & 400 \\
\hline & $16-1$ & 6.17 & 5.50 & 565 & 600 & 500 \\
\hline & $16-2$ & 5.90 & 5.30 & 665 & 700 & 600 \\
\hline \multirow[t]{3}{*}{17} & $17-0$ & 7.27 & 6.60 & 395 & 345 & 310 \\
\hline & $17-1$ & 6.43 & 5.60 & 495 & 445 & 410 \\
\hline & $17-2$ & 6.05 & 6.20 & 595 & 545 & 510 \\
\hline \multirow[t]{3}{*}{18} & $18-0$ & 7.56 & 6.90 & 375 & 290 & 270 \\
\hline & $18-1$ & 6.75 & 6.10 & 475 & 390 & 370 \\
\hline & $18-2$ & 6.46 & 5.70 & 575 & 490 & 470 \\
\hline \multirow[t]{3}{*}{19} & $19-0$ & 7.35 & 6.70 & 440 & 335 & 380 \\
\hline & $19-1$ & 6.75 & 6.00 & 540 & 435 & 480 \\
\hline & $19-2$ & 6.62 & 5.70 & 640 & 535 & 580 \\
\hline \multirow[t]{3}{*}{20} & $20-0$ & 8.29 & & 365 & 350 & 290 \\
\hline & $20-1$ & 7.62 & 6.90 & 465 & 450 & 390 \\
\hline & $20-2$ & 6.77 & 6.20 & 565 & 550 & 490 \\
\hline \multirow[t]{3}{*}{21} & 21-0 & 8.28 & 7.80 & 285 & 280 & 305 \\
\hline & $21-1$ & 7.36 & 6.70 & 385 & 380 & 405 \\
\hline & $21-2$ & 6.55 & 5.80 & 485 & 480 & 605 \\
\hline \multirow[t]{3}{*}{22} & $22-0$ & 8.25 & 7.60 & 345 & 355 & 305 \\
\hline & $22-1$ & 7.71 & 8.80 & 445 & 455 & 405 \\
\hline & $22-2$ & 8.38 & 7.80 & -- & 555 & 505 \\
\hline
\end{tabular}


Appendix 1. Summary of the U.S. Army Corps of Engineers (USACE) data developed in the 1960, 1961, and 1962 surveys on Core Banks, Cape Lookout National Seashore, North Carolina.-Continued

[ft, feet; MSL, mean sea level; --, no data; In 1960-1962, USACE constructed 77 profiles (P); each had 3 or more reference markers (RM) that were 100 ft apart and perpendicular to the shore. RM- 0 is closest to the ocean. The zero reference markers (RM-0) constitute the baseline. Profile 1 is located at Cape Lookout, profile 77 is located at Ocracoke Inlet. All profiles are 3,000 ft apart, except 1 and 2, and 76 and 77, which are 2,400 ft apart]

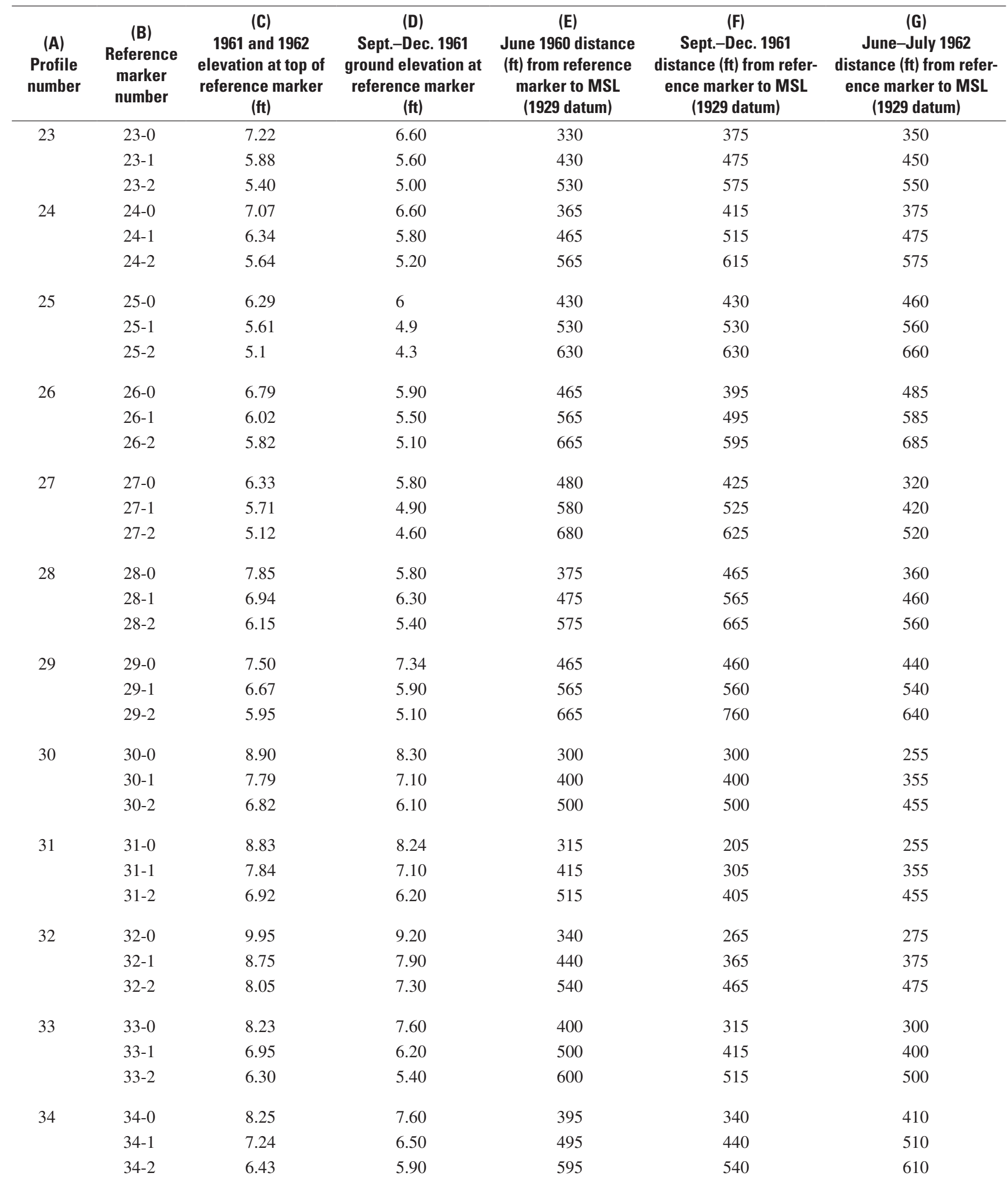


Appendix 1. Summary of the U.S. Army Corps of Engineers (USACE) data developed in the 1960, 1961, and 1962 surveys on Core Banks, Cape Lookout National Seashore, North Carolina.-Continued

[ft, feet; MSL, mean sea level; --, no data; In 1960-1962, USACE constructed 77 profiles (P); each had 3 or more reference markers (RM) that were $100 \mathrm{ft}$ apart and perpendicular to the shore. RM- 0 is closest to the ocean. The zero reference markers (RM- 0 ) constitute the baseline. Profile 1 is located at Cape Lookout, profile 77 is located at Ocracoke Inlet. All profiles are 3,000 ft apart, except 1 and 2, and 76 and 77, which are 2,400 ft apart]

\begin{tabular}{|c|c|c|c|c|c|c|}
\hline $\begin{array}{c}\text { (A) } \\
\text { Profile } \\
\text { number }\end{array}$ & $\begin{array}{l}\text { (B) } \\
\text { Reference } \\
\text { marker } \\
\text { number }\end{array}$ & $\begin{array}{l}\text { (C) } \\
1961 \text { and } 1962 \\
\text { elevation at top of } \\
\text { reference marker } \\
\text { (ft) }\end{array}$ & $\begin{array}{l}\text { (D) } \\
\text { Sept.-Dec. } 1961 \\
\text { ground elevation at } \\
\text { reference marker } \\
\text { (ft) }\end{array}$ & $\begin{array}{c}(\mathrm{E}) \\
\text { June } 1960 \text { distance } \\
\text { (ft) from reference } \\
\text { marker to } \mathrm{MSL} \\
\text { (1929 datum) }\end{array}$ & $\begin{array}{c}\text { (F) } \\
\text { Sept.-Dec. } 1961 \\
\text { distance (ft) from refer- } \\
\text { ence marker to MSL } \\
\text { (1929 datum) }\end{array}$ & $\begin{array}{c}\text { (G) } \\
\text { June-July } 1962 \\
\text { distance (ft) from refer- } \\
\text { ence marker to MSL } \\
\text { (1929 datum) }\end{array}$ \\
\hline \multirow[t]{2}{*}{35} & $35-0$ & 8.18 & -- & 480 & 445 & 450 \\
\hline & $35-1$ & 7.17 & 6.40 & 580 & 545 & 550 \\
\hline \multirow{2}{*}{36} & $36-1$ & 7.48 & 6.90 & 520 & 480 & 480 \\
\hline & $36-2$ & 7.04 & 6.30 & 620 & 580 & 580 \\
\hline \multirow[t]{2}{*}{37} & $37-0$ & 8.15 & 7.20 & 375 & 390 & 365 \\
\hline & $37-1$ & 7.37 & 6.70 & 475 & 490 & 465 \\
\hline \multirow{2}{*}{38} & $38-1$ & 6.79 & 6.70 & 470 & 455 & 480 \\
\hline & $38-2$ & 6.36 & 5.90 & 570 & 555 & 580 \\
\hline \multirow[t]{4}{*}{39} & $39-0$ & 8.16 & 7.60 & 320 & 270 & 250 \\
\hline & $39-1$ & 7.08 & 6.30 & 420 & 370 & 650 \\
\hline & $39-2$ & 6.31 & 5.60 & 520 & 470 & 450 \\
\hline & $39-4$ & 6.23 & 4.50 & 720 & 670 & 650 \\
\hline \multirow[t]{3}{*}{40} & $40-0$ & 8.86 & 8.20 & 310 & 220 & 150 \\
\hline & $40-1$ & 7.78 & 7.00 & 410 & 320 & 250 \\
\hline & $40-2$ & 7.03 & 6.50 & 510 & 420 & 350 \\
\hline \multirow[t]{5}{*}{42} & $42-0$ & 7.23 & 6.60 & 320 & 250 & 235 \\
\hline & $42-1$ & 6.52 & 5.80 & 420 & 350 & 335 \\
\hline & $42-2$ & 5.66 & 4.90 & 520 & 450 & 435 \\
\hline & $42-4$ & 5.36 & 3.90 & 720 & 650 & 635 \\
\hline & $42-6$ & 4.32 & 4.10 & 920 & 850 & 835 \\
\hline \multirow[t]{3}{*}{43} & $43-0$ & 6.36 & 5.70 & 390 & 365 & 220 \\
\hline & $43-1$ & 5.58 & 4.90 & 490 & 465 & 320 \\
\hline & $43-2$ & 5.00 & 4.20 & 590 & 565 & 420 \\
\hline \multirow[t]{3}{*}{44} & $44-0$ & 4.23 & 3.70 & 770 & 600 & 595 \\
\hline & $44-1$ & 3.97 & 3.20 & 870 & 700 & 695 \\
\hline & $44-2$ & 3.88 & 3.10 & 970 & 800 & 795 \\
\hline
\end{tabular}


Appendix 1. Summary of the U.S. Army Corps of Engineers (USACE) data developed in the 1960, 1961, and 1962 surveys on Core Banks, Cape Lookout National Seashore, North Carolina.-Continued

[ft, feet; MSL, mean sea level; --, no data; In 1960-1962, USACE constructed 77 profiles (P); each had 3 or more reference markers (RM) that were 100 ft apart and perpendicular to the shore. RM-0 is closest to the ocean. The zero reference markers (RM-0) constitute the baseline. Profile 1 is located at Cape Lookout, profile 77 is located at Ocracoke Inlet. All profiles are 3,000 ft apart, except 1 and 2, and 76 and 77, which are 2,400 ft apart]

\begin{tabular}{|c|c|c|c|c|c|c|}
\hline $\begin{array}{c}(\mathrm{A}) \\
\text { Profile } \\
\text { number }\end{array}$ & $\begin{array}{c}\text { (B) } \\
\text { Reference } \\
\text { marker } \\
\text { number }\end{array}$ & $\begin{array}{l}\text { (C) } \\
1961 \text { and } 1962 \\
\text { elevation at top of } \\
\text { reference marker } \\
\text { (ft) }\end{array}$ & $\begin{array}{l}\text { (D) } \\
\text { Sept.-Dec. } 1961 \\
\text { ground elevation at } \\
\text { reference marker } \\
\text { (ft) }\end{array}$ & $\begin{array}{c}\text { (E) } \\
\text { June } 1960 \text { distance } \\
\text { (ft) from reference } \\
\text { marker to } \mathrm{MSL} \\
\text { (1929 datum) }\end{array}$ & $\begin{array}{c}\text { (F) } \\
\text { Sept.-Dec. } 1961 \\
\text { distance (ft) from refer- } \\
\text { ence marker to MSL } \\
\text { (1929 datum) }\end{array}$ & $\begin{array}{c}\text { (G) } \\
\text { June-July } 1962 \\
\text { distance (ft) from refer- } \\
\text { ence marker to MSL } \\
\text { (1929 datum) }\end{array}$ \\
\hline \multirow[t]{2}{*}{45} & $45-0$ & 4.65 & 3.90 & 380 & 230 & 625 \\
\hline & $45-1$ & 3.86 & 3.20 & 480 & 330 & 725 \\
\hline \multirow[t]{3}{*}{46} & $46-0$ & 6.66 & 6.00 & 400 & 245 & 270 \\
\hline & 46-1 & 5.51 & 4.80 & 500 & 345 & 370 \\
\hline & $46-2$ & 5.56 & 4.80 & 600 & 445 & 470 \\
\hline 47 & $47-0$ & 7.13 & 6.30 & 400 & 285 & 290 \\
\hline \multirow{2}{*}{48} & $48-1$ & 6.95 & 6.10 & 475 & 490 & 320 \\
\hline & $48-2$ & 6.32 & 5.40 & 575 & 590 & 420 \\
\hline \multirow[t]{4}{*}{49} & $49-0$ & -- & 5.90 & 240 & 130 & 200 \\
\hline & $49-1$ & 5.72 & 5.00 & 340 & 230 & 300 \\
\hline & $49-2$ & 4.79 & 4.10 & 440 & 430 & 400 \\
\hline & $49-4$ & 4.81 & 3.00 & 640 & 630 & 600 \\
\hline \multirow[t]{2}{*}{50} & $50-0$ & 5.64 & 4.80 & 280 & 355 & 240 \\
\hline & $50-1$ & 4.81 & 4.20 & 380 & 455 & 340 \\
\hline \multirow{2}{*}{52} & $52-1$ & 4.29 & 3.40 & 590 & 495 & 510 \\
\hline & $52-2$ & 3.67 & 2.60 & 690 & 595 & 610 \\
\hline \multirow[t]{3}{*}{53} & $53-0$ & 5.11 & 4.50 & 400 & 410 & 350 \\
\hline & 53-1 & 4.45 & 3.70 & 500 & 510 & 450 \\
\hline & $53-2$ & 4.22 & 3.20 & 600 & 610 & 550 \\
\hline \multirow[t]{4}{*}{54} & $54-0$ & 5.30 & 4.50 & 440 & 405 & 320 \\
\hline & 54-1 & 4.12 & 3.50 & 540 & 505 & 420 \\
\hline & $54-2$ & 3.83 & 2.80 & 640 & 605 & 520 \\
\hline & $54-4$ & 4.37 & 2.20 & 840 & 805 & 720 \\
\hline
\end{tabular}


Appendix 1. Summary of the U.S. Army Corps of Engineers (USACE) data developed in the 1960, 1961, and 1962 surveys on Core Banks, Cape Lookout National Seashore, North Carolina.-Continued

[ft, feet; MSL, mean sea level; --, no data; In 1960-1962, USACE constructed 77 profiles (P); each had 3 or more reference markers (RM) that were 100 ft apart and perpendicular to the shore. RM-0 is closest to the ocean. The zero reference markers (RM-0) constitute the baseline. Profile 1 is located at Cape Lookout, profile 77 is located at Ocracoke Inlet. All profiles are 3,000 ft apart, except 1 and 2, and 76 and 77, which are 2,400 ft apart]

\begin{tabular}{|c|c|c|c|c|c|c|}
\hline $\begin{array}{c}\text { (A) } \\
\text { Profile } \\
\text { number }\end{array}$ & $\begin{array}{l}\text { (B) } \\
\text { Reference } \\
\text { marker } \\
\text { number }\end{array}$ & $\begin{array}{l}\text { (C) } \\
1961 \text { and } 1962 \\
\text { elevation at top of } \\
\text { reference marker } \\
\text { (ft) }\end{array}$ & $\begin{array}{l}\text { (D) } \\
\text { Sept.-Dec. } 1961 \\
\text { ground elevation at } \\
\text { reference marker } \\
\text { (ft) }\end{array}$ & $\begin{array}{c}\text { (E) } \\
\text { June } 1960 \text { distance } \\
\text { (ft) from reference } \\
\text { marker to MSL } \\
\text { (1929 datum) }\end{array}$ & $\begin{array}{c}\text { (F) } \\
\text { Sept.-Dec. } 1961 \\
\text { distance (ft) from refer- } \\
\text { ence marker to MSL } \\
\text { (1929 datum) }\end{array}$ & $\begin{array}{c}\text { (G) } \\
\text { June-July } 1962 \\
\text { distance (ft) from refer- } \\
\text { ence marker to MSL } \\
\text { (1929 datum) }\end{array}$ \\
\hline \multirow[t]{3}{*}{55} & $55-0$ & 5.30 & 4.60 & 455 & 400 & 330 \\
\hline & $55-1$ & 4.50 & 4.00 & 555 & 500 & 430 \\
\hline & $55-6$ & 3.53 & 1.80 & 955 & 1,000 & 930 \\
\hline \multirow[t]{3}{*}{56} & $56-0$ & 6.35 & 5.60 & 400 & 340 & 330 \\
\hline & $56-1$ & 5.72 & 5.00 & 500 & 440 & 430 \\
\hline & $56-2$ & 4.82 & 4.00 & 600 & 540 & 530 \\
\hline 57 & $57-2$ & 4.99 & 4.50 & 645 & 570 & 510 \\
\hline \multirow[t]{4}{*}{58} & $58-0$ & 6.92 & 6.10 & 400 & 325 & 335 \\
\hline & $58-1$ & 6.08 & 5.30 & 500 & 425 & 435 \\
\hline & $58-2$ & 8.44 & 8.00 & 600 & 525 & 535 \\
\hline & $58-4$ & 5.50 & 4.10 & 800 & 725 & 735 \\
\hline \multirow[t]{3}{*}{59} & $59-0$ & 5.74 & 5.10 & 425 & 315 & 395 \\
\hline & $59-1$ & 5.04 & 4.30 & 525 & 415 & 495 \\
\hline & $59-2$ & 5.03 & 4.00 & 625 & 515 & 595 \\
\hline \multirow[t]{4}{*}{62} & $62-0$ & 4.51 & 3.45 & 620 & 445 & 560 \\
\hline & $62-1$ & 4.23 & 3.20 & 720 & 545 & 660 \\
\hline & $62-2$ & 3.75 & 2.90 & 820 & 645 & 760 \\
\hline & $62-4$ & 3.43 & 2.60 & 1,020 & 845 & 960 \\
\hline \multirow[t]{3}{*}{63} & $63-0$ & 4.19 & 3.30 & 625 & 560 & 435 \\
\hline & $63-1$ & 4.03 & 3.00 & 725 & 660 & 534 \\
\hline & $63-2$ & 3.71 & 2.90 & 825 & 760 & 635 \\
\hline \multirow[t]{4}{*}{64} & $64-0$ & 5.20 & 4.50 & 500 & 455 & 405 \\
\hline & $64-1$ & 4.76 & 4.10 & 600 & 555 & 505 \\
\hline & $64-2$ & 4.14 & 3.40 & 700 & 655 & 605 \\
\hline & $64-4$ & 4.53 & 2.30 & 900 & 855 & 805 \\
\hline
\end{tabular}


Appendix 1. Summary of the U.S. Army Corps of Engineers (USACE) data developed in the 1960, 1961, and 1962 surveys on Core Banks, Cape Lookout National Seashore, North Carolina.-Continued

[ft, feet; MSL, mean sea level; --, no data; In 1960-1962, USACE constructed 77 profiles (P); each had 3 or more reference markers (RM) that were 100 ft apart and perpendicular to the shore. RM-0 is closest to the ocean. The zero reference markers (RM-0) constitute the baseline. Profile 1 is located at Cape Lookout, profile 77 is located at Ocracoke Inlet. All profiles are 3,000 ft apart, except 1 and 2, and 76 and 77, which are 2,400 ft apart]

\begin{tabular}{|c|c|c|c|c|c|c|}
\hline $\begin{array}{c}\text { (A) } \\
\text { Profile } \\
\text { number }\end{array}$ & $\begin{array}{c}\text { (B) } \\
\text { Reference } \\
\text { marker } \\
\text { number }\end{array}$ & $\begin{array}{l}\text { (C) } \\
1961 \text { and } 1962 \\
\text { elevation at top of } \\
\text { reference marker } \\
\text { (ft) }\end{array}$ & $\begin{array}{l}\text { (D) } \\
\text { Sept.-Dec. } 1961 \\
\text { ground elevation at } \\
\text { reference marker } \\
\text { (ft) }\end{array}$ & $\begin{array}{c}\text { (E) } \\
\text { June } 1960 \text { distance } \\
\text { (ft) from reference } \\
\text { marker to MSL } \\
\text { (1929 datum) }\end{array}$ & $\begin{array}{c}\text { (F) } \\
\text { Sept.-Dec. } 1961 \\
\text { distance (ft) from refer- } \\
\text { ence marker to MSL } \\
\text { (1929 datum) }\end{array}$ & $\begin{array}{c}\text { (G) } \\
\text { June-July } 1962 \\
\text { distance (ft) from refer- } \\
\text { ence marker to MSL } \\
\text { (1929 datum) }\end{array}$ \\
\hline \multirow[t]{3}{*}{65} & $65-0$ & 5.47 & 4.70 & 580 & 455 & 430 \\
\hline & $65-1$ & 4.76 & 4.20 & 680 & 555 & 530 \\
\hline & $65-4$ & 4.52 & 2.50 & 980 & 855 & 830 \\
\hline \multirow[t]{4}{*}{66} & $66-0$ & 4.84 & 3.90 & 700 & 495 & 450 \\
\hline & $66-1$ & 4.19 & 3.50 & 800 & 595 & 550 \\
\hline & $66-2$ & 3.81 & 3.10 & 900 & 695 & 650 \\
\hline & $66-4$ & 4.11 & 2.50 & 1,100 & 895 & 850 \\
\hline \multirow{2}{*}{67} & $67-2$ & 3.82 & 3.10 & 855 & 765 & 660 \\
\hline & $67-4$ & 3.81 & 1.70 & 1,055 & 965 & 860 \\
\hline \multirow[t]{6}{*}{68} & $68-0$ & 3.86 & 2.80 & 710 & 660 & 465 \\
\hline & $68-1$ & 4.35 & 3.20 & 810 & 760 & 565 \\
\hline & $68-2$ & 4.36 & 3.20 & 910 & 860 & 665 \\
\hline & $68-4$ & 3.21 & 2.70 & 1,110 & 1,060 & 865 \\
\hline & $68-6$ & 3.00 & 0.60 & 1,320 & 1,260 & 1,065 \\
\hline & $68-8$ & 2.46 & -1.30 & 1,520 & 1,460 & 1,265 \\
\hline 69 & $69-0$ & 5.60 & 4.60 & 580 & 425 & 430 \\
\hline 70 & $70-4$ & 4.23 & 2.00 & 900 & 710 & 735 \\
\hline \multirow[t]{6}{*}{71} & $71-0$ & 4.67 & 3.40 & 400 & 300 & 300 \\
\hline & $71-1$ & 5.40 & 4.30 & 500 & 400 & 400 \\
\hline & $71-2$ & 5.30 & 4.10 & 600 & 500 & 500 \\
\hline & $71-4$ & 4.78 & 3.10 & 800 & 700 & 700 \\
\hline & $71-6$ & 3.98 & 2.70 & 1,000 & 900 & 900 \\
\hline & $71-8$ & 3.63 & -- & 1,200 & 1,100 & 1,100 \\
\hline \multirow[t]{6}{*}{72} & $72-0$ & 5.77 & 4.60 & 340 & 185 & 190 \\
\hline & $72-1$ & 5.98 & 4.90 & 440 & 285 & 290 \\
\hline & $72-2$ & 5.20 & 4.30 & 540 & 385 & 390 \\
\hline & $72-4$ & 5.24 & 3.30 & 740 & 585 & 590 \\
\hline & $72-6$ & 4.55 & -- & 940 & 785 & 790 \\
\hline & $72-8$ & 4.09 & -- & 1,140 & 985 & 990 \\
\hline
\end{tabular}


Appendix 1. Summary of the U.S. Army Corps of Engineers (USACE) data developed in the 1960, 1961, and 1962 surveys on Core Banks, Cape Lookout National Seashore, North Carolina.-Continued

[ft, feet; MSL, mean sea level; --, no data; In 1960-1962, USACE constructed 77 profiles (P); each had 3 or more reference markers (RM) that were $100 \mathrm{ft}$ apart and perpendicular to the shore. RM-0 is closest to the ocean. The zero reference markers (RM- 0 ) constitute the baseline. Profile 1 is located at Cape Lookout, profile 77 is located at Ocracoke Inlet. All profiles are 3,000 ft apart, except 1 and 2, and 76 and 77, which are 2,400 ft apart]

\begin{tabular}{|c|c|c|c|c|c|c|}
\hline $\begin{array}{c}\text { (A) } \\
\text { Profile } \\
\text { number }\end{array}$ & $\begin{array}{l}\text { (B) } \\
\text { Reference } \\
\text { marker } \\
\text { number }\end{array}$ & $\begin{array}{c}\text { (C) } \\
1961 \text { and } 1962 \\
\text { elevation at top of } \\
\text { reference marker } \\
\text { (ft) }\end{array}$ & $\begin{array}{c}\text { (D) } \\
\text { Sept.-Dec. 1961 } \\
\text { ground elevation at } \\
\text { reference marker } \\
\text { (ft) }\end{array}$ & $\begin{array}{c}(\mathrm{E}) \\
\text { June } 1960 \text { distance } \\
\text { (ft) from reference } \\
\text { marker to MSL } \\
\text { (1929 datum) }\end{array}$ & $\begin{array}{c}\text { (F) } \\
\text { Sept.-Dec. } 1961 \\
\text { distance (ft) from refer- } \\
\text { ence marker to MSL } \\
\text { (1929 datum) }\end{array}$ & $\begin{array}{c}\text { (G) } \\
\text { June-July } 1962 \\
\text { distance ( } \mathrm{ft} \text { ) from refer- } \\
\text { ence marker to MSL } \\
\text { (1929 datum) }\end{array}$ \\
\hline \multirow[t]{6}{*}{73} & 73-0 & 6.43 & 5.10 & 330 & 175 & 180 \\
\hline & 73-1 & 6.08 & 5.10 & 430 & 275 & 280 \\
\hline & $73-2$ & 5.18 & 4.20 & 530 & 375 & 380 \\
\hline & 73-4 & 3.95 & 2.70 & 730 & 575 & 580 \\
\hline & 73-6 & 3.89 & -- & 930 & 775 & 780 \\
\hline & 73-8 & 3.67 & -- & 1,130 & 975 & 980 \\
\hline \multirow[t]{5}{*}{74} & 74-0 & 6.21 & 5.00 & 400 & 270 & 220 \\
\hline & 74-1 & 5.61 & 4.50 & 500 & 370 & 320 \\
\hline & $74-2$ & 4.90 & 3.70 & 600 & 470 & 420 \\
\hline & 74-4 & 4.82 & 3.00 & 800 & 670 & 620 \\
\hline & 74-6 & 4.33 & -- & 1,000 & 870 & 820 \\
\hline \multirow[t]{3}{*}{75} & 75-0 & 5.10 & 3.90 & 555 & 500 & 480 \\
\hline & $75-1$ & 4.44 & 3.40 & 655 & 600 & 580 \\
\hline & $75-2$ & 4.05 & 3.20 & 755 & 700 & 680 \\
\hline \multirow[t]{3}{*}{76} & 76-0 & 4.38 & 2.90 & 800 & 745 & 760 \\
\hline & 76-1 & 3.94 & 2.70 & 900 & 845 & 860 \\
\hline & $76-2$ & 3.59 & 2.70 & 1,000 & 945 & 960 \\
\hline \multirow[t]{3}{*}{77} & $77-0$ & 3.50 & 2.30 & 750 & 820 & 770 \\
\hline & 77-1 & 3.36 & 2.10 & 850 & 920 & 870 \\
\hline & $77-2$ & 3.20 & 2.10 & 950 & 1,020 & 970 \\
\hline \multirow[t]{3}{*}{76} & $76-0$ & 4.38 & 2.90 & 800 & 745 & 760 \\
\hline & 76-1 & 3.94 & 2.70 & 900 & 845 & 860 \\
\hline & $76-2$ & 3.59 & 2.70 & 1,000 & 945 & 960 \\
\hline \multirow[t]{3}{*}{77} & 77-0 & 3.50 & 2.30 & 750 & 820 & 770 \\
\hline & $77-1$ & 3.36 & 2.10 & 850 & 920 & 870 \\
\hline & $77-2$ & 3.20 & 2.10 & 950 & 1,020 & 970 \\
\hline
\end{tabular}


Appendix 2. Summary of the U.S. Army Corps of Engineers (USACE, 1964) 1961 survey data of the shoreface bathymetry for Core Banks, Cape Lookout National Seashore, North Carolina.

[ft, feet; MSL, mean sea level; USACE, U.S. Army Corps of Engineers]

\begin{tabular}{|c|c|c|c|c|c|}
\hline \multirow{2}{*}{ Profile number } & \multicolumn{5}{|c|}{ Horizontal distance (ft) from the MSL shoreline (1929 datum) to bathymetric contours of the USACE 1961 survey } \\
\hline & $-6 \mathrm{ft}$ & $-12 \mathrm{ft}$ & $-18 \mathrm{ft}$ & $-24 \mathrm{ft}$ & $-30 \mathrm{ft}$ \\
\hline 1 & 105 & 955 & 1,725 & 4,325 & 6,235 \\
\hline 3 & 50 & 620 & 1,060 & 2,720 & 5,120 \\
\hline 5 & 240 & 530 & 1,200 & 1,860 & 5,770 \\
\hline 7 & 70 & 570 & 840 & 1,020 & 5,590 \\
\hline 9 & 130 & 610 & 810 & 1,620 & 3,790 \\
\hline 11 & 230 & 540 & 950 & 1,640 & 2,800 \\
\hline 13 & 70 & 550 & 750 & 1,240 & 2,060 \\
\hline 15 & 160 & 610 & 950 & 1,570 & 2,770 \\
\hline 17 & 160 & 720 & 1,200 & 1,960 & 2,780 \\
\hline 19 & 190 & 640 & 1,090 & 1,790 & 2,450 \\
\hline 21 & 170 & 700 & 1,060 & 1,670 & 2,500 \\
\hline 23 & 100 & 550 & 960 & 1,770 & 2,030 \\
\hline 25 & 70 & 210 & 990 & 1,260 & 2,500 \\
\hline 27 & 140 & 730 & 970 & 1,560 & 2,380 \\
\hline 29 & 190 & 440 & 950 & 1,260 & 1,830 \\
\hline 31 & 40 & 800 & 1,020 & 1,210 & 1,790 \\
\hline 33 & 140 & 640 & 990 & 1,530 & 2,360 \\
\hline 35 & 140 & 190 & 1,030 & 1,290 & 2,010 \\
\hline 37 & 120 & 200 & 1,020 & 1,330 & 1,870 \\
\hline 39 & 100 & 200 & 1,020 & 1,390 & 2,280 \\
\hline 41 & 150 & 210 & 1,090 & 1,520 & 2,460 \\
\hline 43 & 220 & 360 & 1,190 & 1,720 & 2,800 \\
\hline 46 & 240 & 450 & 1,370 & 2,110 & 2,720 \\
\hline 48 & 280 & 360 & 1,410 & 1,940 & 2,870 \\
\hline 50 & 290 & 440 & 1,270 & 1,990 & 3,030 \\
\hline 52 & 360 & 570 & 1,450 & 1,940 & 2,830 \\
\hline 54 & 350 & 470 & 1,360 & 1,880 & 2,130 \\
\hline 56 & 190 & 470 & 1,340 & 1,820 & 2,650 \\
\hline 58 & 320 & 480 & 920 & 1,870 & 2,410 \\
\hline 60 & 250 & 450 & 820 & 1,860 & 2,380 \\
\hline 62 & 400 & 640 & 1,480 & 2,120 & 2,760 \\
\hline 64 & 90 & 370 & 870 & 1,860 & 2,430 \\
\hline 66 & 350 & 520 & 1,420 & 2,030 & 2,850 \\
\hline 68 & 470 & 720 & 1,880 & 2,380 & 3,040 \\
\hline 70 & 480 & 680 & 1,560 & 1,970 & 2,690 \\
\hline 72 & 260 & 710 & 1,530 & 2,500 & 2,980 \\
\hline 74 & 310 & 730 & 970 & 2,350 & 3,490 \\
\hline 76 & 680 & 1,070 & 2,700 & 4,540 & 6,780 \\
\hline
\end{tabular}


Appendix 3. Summary of the 1970 survey of Godfrey and Godfrey (1976) concerning change in surface elevation relative to the reference markers recovered on 69 of the 77 U.S. Army Corps of Engineers profiles established on Core Banks, Cape Lookout National Seashore, North Carolina.

[ft, feet; G\&G, Godfrey and Godfrey; --, no data]

\begin{tabular}{|c|c|}
\hline $\begin{array}{l}\text { Reference marker } \\
\text { number }\end{array}$ & $\begin{array}{l}\text { Change in surface elevation between } \\
1960 \text { and } 1970 \text { (ft) (from G\&G fig. 20) }\end{array}$ \\
\hline $1 \mathrm{~A}-0$ & -- \\
\hline $1 \mathrm{~A}-1$ & 1.22 \\
\hline $1 \mathrm{~A}-2$ & 0.79 \\
\hline $2-0$ & -- \\
\hline $2-1$ & -- \\
\hline $2-2$ & -- \\
\hline $3-0$ & -- \\
\hline $3-1$ & 1.01 \\
\hline $3-2$ & 1.14 \\
\hline $4-0$ & -- \\
\hline $4-1$ & -- \\
\hline $4-2$ & 1.02 \\
\hline $5-0$ & -- \\
\hline $5-1$ & -- \\
\hline $5-2$ & -- \\
\hline $5-4$ & -- \\
\hline $6-0$ & 0.49 \\
\hline $6-1$ & -- \\
\hline $6-2$ & 0.73 \\
\hline $7-0$ & 2.63 \\
\hline $7-1$ & 0.84 \\
\hline $7-2$ & 1.06 \\
\hline $8-0$ & 0.62 \\
\hline $8-1$ & 0.65 \\
\hline $8-2$ & 0.84 \\
\hline $9-0$ & -- \\
\hline $9-1$ & 0.56 \\
\hline $9-2$ & 0.82 \\
\hline $10-0$ & -- \\
\hline $10-1$ & -- \\
\hline $10-2$ & 1.18 \\
\hline
\end{tabular}

Appendix 3. Summary of the 1970 survey of Godfrey and Godfrey (1976) concerning change in surface elevation relative to the reference markers recovered on 69 of the 77 U.S. Army Corps of Engineers profiles established on Core Banks, Cape Lookout National Seashore, North Carolina.-Continued

[ft, feet; G\&G, Godfrey and Godfrey; --, no data]

\begin{tabular}{|c|c|}
\hline $\begin{array}{c}\text { Reference marker } \\
\text { number }\end{array}$ & $\begin{array}{l}\text { Change in surface elevation between } \\
1960 \text { and } 1970 \text { (ft) (from G\&G fig. 20) }\end{array}$ \\
\hline $11-0$ & -- \\
\hline $11-1$ & -- \\
\hline $11-2$ & -- \\
\hline $12-0$ & -- \\
\hline $12-1$ & 1.59 \\
\hline $12-2$ & 2.60 \\
\hline $13-0$ & -- \\
\hline $13-1$ & 2.07 \\
\hline $13-2$ & 1.80 \\
\hline $14-0$ & 0.36 \\
\hline $14-1$ & 0.95 \\
\hline $14-2$ & 1.58 \\
\hline $15-0$ & 0.10 \\
\hline $15-1$ & -- \\
\hline $15-2$ & 1.26 \\
\hline $16-0$ & 0.84 \\
\hline $16-1$ & 1.00 \\
\hline $16-2$ & 1.91 \\
\hline $17-0$ & 0.28 \\
\hline $17-1$ & -- \\
\hline $17-2$ & -0.05 \\
\hline $18-0$ & -- \\
\hline $18-1$ & -- \\
\hline $18-2$ & -- \\
\hline $19-0$ & 0.98 \\
\hline $19-1$ & 0.95 \\
\hline $19-2$ & 1.28 \\
\hline $20-0$ & -- \\
\hline $20-1$ & -- \\
\hline $20-2$ & 0.67 \\
\hline
\end{tabular}


Appendix 3. Summary of the 1970 survey of Godfrey and Godfrey (1976) concerning change in surface elevation relative to the reference markers recovered on 69 of the 77 U.S. Army Corps of Engineers profiles established on Core Banks, Cape Lookout National Seashore, North Carolina.-Continued

[ft, feet; G\&G, Godfrey and Godfrey; --, no data]

\begin{tabular}{|c|c|}
\hline $\begin{array}{c}\text { Reference marker } \\
\text { number }\end{array}$ & $\begin{array}{l}\text { Change in surface elevation between } \\
1960 \text { and } 1970 \text { (ft) (from G\&G fig. 20) }\end{array}$ \\
\hline $21-0$ & 0.48 \\
\hline $21-1$ & 1.12 \\
\hline $21-2$ & 1.34 \\
\hline $22-0$ & -- \\
\hline $22-1$ & -1.12 \\
\hline $22-2$ & 0.71 \\
\hline $23-0$ & 0.55 \\
\hline $23-1$ & 0.64 \\
\hline $23-2$ & 0.92 \\
\hline $24-0$ & 0.60 \\
\hline 24-1 & 0.70 \\
\hline $24-2$ & 0.77 \\
\hline $25-0$ & -- \\
\hline $25-1$ & -- \\
\hline $25-2$ & 2.28 \\
\hline $26-0$ & -- \\
\hline $26-1$ & -- \\
\hline $26-2$ & -- \\
\hline $27-0$ & -- \\
\hline $27-1$ & 1.27 \\
\hline $27-2$ & 2.00 \\
\hline $28-0$ & -- \\
\hline $28-1$ & -- \\
\hline $28-2$ & -- \\
\hline $29-0$ & -- \\
\hline $29-1$ & -- \\
\hline $29-2$ & -- \\
\hline $30-0$ & 0.67 \\
\hline $30-1$ & 0.95 \\
\hline $30-2$ & 0.92 \\
\hline $31-0$ & 0.92 \\
\hline $31-1$ & 1.20 \\
\hline $31-2$ & 1.08 \\
\hline
\end{tabular}

Appendix 3. Summary of the 1970 survey of Godfrey and Godfrey (1976) concerning change in surface elevation relative to the reference markers recovered on 69 of the 77 U.S. Army Corps of Engineers profiles established on Core Banks, Cape Lookout National Seashore, North Carolina.-Continued

[ft, feet; G\&G, Godfrey and Godfrey; --, no data]

\begin{tabular}{|c|c|}
\hline $\begin{array}{l}\text { Reference marker } \\
\text { number }\end{array}$ & $\begin{array}{l}\text { Change in surface elevation between } \\
1960 \text { and } 1970 \text { (ft) (from G\&G fig. 20) }\end{array}$ \\
\hline $32-0$ & 0.75 \\
\hline $32-1$ & 1.05 \\
\hline $32-2$ & 1.08 \\
\hline $33-0$ & 1.48 \\
\hline $33-1$ & 1.70 \\
\hline $33-2$ & 1.59 \\
\hline $34-0$ & 0.85 \\
\hline $34-1$ & 1.10 \\
\hline $34-2$ & 1.05 \\
\hline $35-0$ & -- \\
\hline $35-1$ & 1.03 \\
\hline $35-2$ & 1.12 \\
\hline $36-0$ & --- \\
\hline $36-1$ & 1.17 \\
\hline $36-2$ & 1.56 \\
\hline $37-0$ & 0.95 \\
\hline $37-1$ & 2.41 \\
\hline $37-2$ & 1.57 \\
\hline $38-0$ & 0.53 \\
\hline $38-1$ & 0.88 \\
\hline $38-2$ & 1.18 \\
\hline $39-0$ & -- \\
\hline $39-1$ & -- \\
\hline $39-2$ & 1.33 \\
\hline $39-4$ & -- \\
\hline $40-0$ & -- \\
\hline $40-1$ & 0.45 \\
\hline $40-2$ & 2.50 \\
\hline $40-4$ & -- \\
\hline $41-0$ & -- \\
\hline $41-1$ & -- \\
\hline $41-2$ & -- \\
\hline $41-4$ & -- \\
\hline $41-6$ & -- \\
\hline
\end{tabular}


Appendix 3. Summary of the 1970 survey of Godfrey and Godfrey (1976) concerning change in surface elevation relative to the reference markers recovered on 69 of the 77 U.S. Army Corps of Engineers profiles established on Core Banks, Cape Lookout National Seashore, North Carolina.-Continued

[ft, feet; G\&G, Godfrey and Godfrey; --, no data]

\begin{tabular}{|c|c|}
\hline $\begin{array}{l}\text { Reference marker } \\
\text { number }\end{array}$ & $\begin{array}{l}\text { Change in surface elevation between } \\
1960 \text { and } 1970 \text { (ft) (from G\&G fig. 20) }\end{array}$ \\
\hline $42-0$ & -- \\
\hline $42-1$ & -- \\
\hline $42-2$ & -1.34 \\
\hline $42-4$ & 2.31 \\
\hline $42-6$ & 0.68 \\
\hline $43-0$ & -- \\
\hline $43-1$ & -- \\
\hline $43-2$ & 1.69 \\
\hline $44-0$ & -- \\
\hline $44-1$ & -- \\
\hline $44-2$ & -- \\
\hline $45-0$ & -- \\
\hline $45-1$ & -- \\
\hline $45-2$ & -- \\
\hline $46-0$ & -0.46 \\
\hline $46-1$ & 0.87 \\
\hline $46-2$ & 0.40 \\
\hline $47-0$ & -1.60 \\
\hline $47-1$ & -0.29 \\
\hline $47-2$ & 1.63 \\
\hline $48-0$ & 0.61 \\
\hline $48-1$ & 3.87 \\
\hline $48-2$ & 1.58 \\
\hline $49-0$ & -- \\
\hline $49-1$ & -- \\
\hline $49-2$ & 1.35 \\
\hline $49-4$ & 2.63 \\
\hline $50-0$ & -- \\
\hline $50-1$ & 0.71 \\
\hline $50-2$ & 0.95 \\
\hline $51-0$ & 1.65 \\
\hline $51-1$ & 1.33 \\
\hline $51-2$ & 1.25 \\
\hline
\end{tabular}

Appendix 3. Summary of the 1970 survey of Godfrey and Godfrey (1976) concerning change in surface elevation relative to the reference markers recovered on 69 of the 77 U.S. Army Corps of Engineers profiles established on Core Banks, Cape Lookout National Seashore, North Carolina.-Continued

[ft, feet; G\&G, Godfrey and Godfrey; --, no data]

\begin{tabular}{|c|c|}
\hline $\begin{array}{l}\text { Reference marker } \\
\text { number }\end{array}$ & $\begin{array}{l}\text { Change in surface elevation between } \\
1960 \text { and } 1970 \text { (ft) (from G\&G fig. 20) }\end{array}$ \\
\hline $52-0$ & -- \\
\hline $52-1$ & -- \\
\hline $52-2$ & -- \\
\hline $53-0$ & 1.43 \\
\hline $53-1$ & 0.95 \\
\hline $53-2$ & 1.38 \\
\hline $54-0$ & -- \\
\hline $54-1$ & -- \\
\hline $54-2$ & -- \\
\hline $54-4$ & -- \\
\hline $55-0$ & -- \\
\hline $55-1$ & -- \\
\hline $55-2$ & -- \\
\hline $55-4$ & -- \\
\hline $55-6$ & -- \\
\hline $56-0$ & 0.23 \\
\hline 56-1 & 1.38 \\
\hline $56-2$ & 1.48 \\
\hline $57-0$ & -0.09 \\
\hline $57-1$ & 1.11 \\
\hline $57-2$ & 1.08 \\
\hline $58-0$ & 0.43 \\
\hline $58-1$ & 0.78 \\
\hline $58-2$ & -- \\
\hline $58-4$ & -- \\
\hline 59-0 & 0.71 \\
\hline $59-1$ & 0.74 \\
\hline $59-2$ & 1.62 \\
\hline $60-0$ & 0.29 \\
\hline $60-1$ & 0.38 \\
\hline $60-2$ & 0.75 \\
\hline $61-0$ & -0.09 \\
\hline $61-1$ & -- \\
\hline $61-2$ & 5.01 \\
\hline
\end{tabular}


Appendix 3. Summary of the 1970 survey of Godfrey and Godfrey (1976) concerning change in surface elevation relative to the reference markers recovered on 69 of the 77 U.S. Army Corps of Engineers profiles established on Core Banks, Cape Lookout National Seashore, North Carolina.-Continued

[ft, feet; G\&G, Godfrey and Godfrey; --, no data]

\begin{tabular}{|c|c|}
\hline $\begin{array}{l}\text { Reference marker } \\
\text { number }\end{array}$ & $\begin{array}{l}\text { Change in surface elevation between } \\
1960 \text { and } 1970 \text { (ft) (from G\&G fig. 20) }\end{array}$ \\
\hline $62-0$ & -- \\
\hline $62-1$ & -- \\
\hline $62-2$ & -- \\
\hline $62-4$ & -- \\
\hline $63-0$ & 0.40 \\
\hline $63-1$ & 1.03 \\
\hline $63-2$ & 0.88 \\
\hline $64-0$ & -- \\
\hline 64-1 & -- \\
\hline $64-2$ & 0.97 \\
\hline $64-4$ & 1.48 \\
\hline $65-0$ & -- \\
\hline $65-1$ & -0.29 \\
\hline $65-2$ & 0.74 \\
\hline $65-4$ & 1.30 \\
\hline $66-0$ & -- \\
\hline $66-1$ & -0.56 \\
\hline $66-2$ & -0.08 \\
\hline $66-4$ & 0.92 \\
\hline $67-0$ & -- \\
\hline $67-1$ & 0.10 \\
\hline $67-2$ & 0.10 \\
\hline $67-4$ & 1.45 \\
\hline $68-0$ & -- \\
\hline $68-1$ & -- \\
\hline $68-2$ & -- \\
\hline $68-4$ & -0.77 \\
\hline $68-6$ & 3.06 \\
\hline $68-8$ & -- \\
\hline $69-0$ & -- \\
\hline $69-1$ & -- \\
\hline $69-2$ & 0.47 \\
\hline $69-4$ & -- \\
\hline
\end{tabular}

Appendix 3. Summary of the 1970 survey of Godfrey and Godfrey (1976) concerning change in surface elevation relative to the reference markers recovered on 69 of the 77 U.S. Army Corps of Engineers profiles established on Core Banks, Cape Lookout National Seashore, North Carolina.-Continued

[ft, feet; G\&G, Godfrey and Godfrey; --, no data]

\begin{tabular}{|c|c|}
\hline $\begin{array}{l}\text { Reference marker } \\
\text { number }\end{array}$ & $\begin{array}{l}\text { Change in surface elevation between } \\
1960 \text { and } 1970 \text { (ft) (from G\&G fig. 20) }\end{array}$ \\
\hline 70-0 & 1.57 \\
\hline $70-1$ & -- \\
\hline $70-2$ & 7.19 \\
\hline 70-4 & 1.74 \\
\hline 71-0 & -- \\
\hline 71-1 & -- \\
\hline $71-2$ & -- \\
\hline $71-4$ & -- \\
\hline $71-6$ & -- \\
\hline $71-8$ & -- \\
\hline $72-0$ & -- \\
\hline $72-1$ & -- \\
\hline $72-2$ & -- \\
\hline $72-4$ & 0.40 \\
\hline $72-6$ & -- \\
\hline $72-8$ & -- \\
\hline 73-0 & -- \\
\hline $73-1$ & -- \\
\hline $73-2$ & -- \\
\hline 73-4 & 0.89 \\
\hline $73-6$ & -- \\
\hline $73-8$ & 3.34 \\
\hline 74-0 & -- \\
\hline 74-1 & -- \\
\hline $74-2$ & 0.41 \\
\hline 74-4 & 1.00 \\
\hline 74-6 & -- \\
\hline $75-0$ & 0.61 \\
\hline $75-1$ & 1.07 \\
\hline $75-2$ & 1.05 \\
\hline $76-0$ & 1.48 \\
\hline 76-1 & 1.44 \\
\hline $76-2$ & 1.71 \\
\hline $77-0$ & 1.33 \\
\hline $77-1$ & 1.36 \\
\hline $77-2$ & 1.20 \\
\hline
\end{tabular}


Appendix 4. Summary of the 1971 Godfrey and Godfrey (1976) shoreline change survey data for 39 selected profiles of the 77 U.S. Army Corps of Engineers profiles established on Core Banks, Cape Lookout National Seashore, North Carolina.

[ft, feet; ft/yr, feet per year; USACE, U.S. Army Corps of Engineers; G\&G, Godfrey and Godfrey]

\begin{tabular}{|c|c|c|}
\hline $\begin{array}{l}\text { USACE profile } \\
\text { number }\end{array}$ & $\begin{array}{l}\text { G\&G 1962-1971 net } \\
\text { shoreline change (ft) }\end{array}$ & $\begin{array}{c}\text { G\&G 1962-1971 rate of } \\
\text { shoreline change (ft/yr) }\end{array}$ \\
\hline 1 & 328 & 36 \\
\hline 3 & -43 & -5 \\
\hline 5 & 144 & 16 \\
\hline 7 & 10 & 1 \\
\hline 9 & 194 & 22 \\
\hline 10 & 10 & 1 \\
\hline 13 & 39 & 4 \\
\hline 15 & 20 & 2 \\
\hline 19 & 26 & 3 \\
\hline 21 & -62 & -7 \\
\hline 22 & 26 & 3 \\
\hline 25 & -39 & -4 \\
\hline 27 & 118 & 13 \\
\hline 29 & -20 & -2 \\
\hline 31 & 16 & 2 \\
\hline 33 & 7 & 1 \\
\hline 35 & -98 & -11 \\
\hline 37 & -82 & -9 \\
\hline 39 & 89 & 10 \\
\hline 40 & 115 & 13 \\
\hline 42 & 154 & 17 \\
\hline 43 & 236 & 26 \\
\hline 47 & 79 & 9 \\
\hline 48 & 131 & 15 \\
\hline 50 & 95 & 11 \\
\hline 51 & 98 & 11 \\
\hline 53 & 131 & 15 \\
\hline 56 & 85 & 9 \\
\hline 57 & 49 & 5 \\
\hline 59 & 85 & 9 \\
\hline 61 & 148 & 16 \\
\hline 63 & 184 & 20 \\
\hline 65 & 180 & 20 \\
\hline 66 & 203 & 23 \\
\hline 69 & 197 & 22 \\
\hline 71 & 453 & 50 \\
\hline 73 & 322 & 36 \\
\hline 75 & 62 & 7 \\
\hline 77 & 492 & 55 \\
\hline
\end{tabular}


Appendix 5. Latitude and longitude for the recovered U.S. Army Corps of Engineers (1964) reference markers and that were resurveyed in 2001 by East Carolina University for the present study on Core Banks, Cape Lookout National Seashore, North Carolina.

[1-0 represents profile $\mathrm{P} 1$, and reference marker RM-0; $2-2$ represents profile $\mathrm{P} 2$, and reference marker RM-2]

\begin{tabular}{|c|c|c|}
\hline \multicolumn{3}{|c|}{ Reference markers recovered in 2001} \\
\hline Reference marker & $\begin{array}{l}\text { Latitude north } \\
\text { decimal degrees }\end{array}$ & $\begin{array}{l}\text { Longitude west } \\
\text { decimal degrees }\end{array}$ \\
\hline $1-0$ & 34.902950 & -76.250433 \\
\hline $2-2$ & 34.597683 & -76.533583 \\
\hline $3-2$ & 34.605600 & -76.530533 \\
\hline $4-1$ & 34.613050 & -76.526217 \\
\hline $4-2$ & 34.613150 & -76.526567 \\
\hline $5-2$ & 34.620733 & -76.522583 \\
\hline $5-4$ & 34.621000 & -76.523150 \\
\hline $6-0$ & 34.627800 & -76.517383 \\
\hline $6-1$ & 34.627950 & -76.517700 \\
\hline $6-2$ & 34.628067 & -76.517983 \\
\hline $7-0$ & 34.635117 & -76.512783 \\
\hline $7-1$ & 34.635233 & -76.513050 \\
\hline $7-2$ & 34.635383 & -76.513367 \\
\hline $8-1$ & 34.642567 & -76.508467 \\
\hline $8-2$ & 34.642700 & -76.508767 \\
\hline $9-1$ & 34.649867 & -76.503867 \\
\hline $9-2$ & 34.650000 & -76.504150 \\
\hline $10-1$ & 34.657200 & -76.499233 \\
\hline $10-2$ & 34.657317 & -76.499500 \\
\hline $11-0$ & 34.664383 & -76.494317 \\
\hline $11-1$ & 34.664533 & -76.494567 \\
\hline $11-2$ & 34.664683 & -76.494850 \\
\hline $12-0$ & 34.671183 & -76.488667 \\
\hline $12-1$ & 34.671333 & -76.488933 \\
\hline $12-2$ & 34.671533 & -76.489233 \\
\hline $13-0$ & 34.678000 & -76.483033 \\
\hline $13-1$ & 34.678200 & -76.483233 \\
\hline $13-2$ & 34.678300 & -76.483583 \\
\hline
\end{tabular}

Appendix 5. Latitude and longitude for the recovered U.S. Army Corps of Engineers (1964) reference markers and that were resurveyed in 2001 by East Carolina University for the present study on Core Banks, Cape Lookout National Seashore, North Carolina.-Continued

[1-0 represents profile $\mathrm{P} 1$, and reference marker RM-0; $2-2$ represents profile $\mathrm{P} 2$, and reference marker RM-2]

\section{Reference markers recovered in 2001}

\begin{tabular}{|c|c|c|}
\hline Reference marker & $\begin{array}{l}\text { Latitude north } \\
\text { decimal degrees }\end{array}$ & $\begin{array}{l}\text { Longitude west } \\
\text { decimal degrees }\end{array}$ \\
\hline $14-0$ & 34.684783 & -76.477400 \\
\hline $14-1$ & 34.684950 & -76.477683 \\
\hline $14-2$ & 34.685117 & -76.477983 \\
\hline $15-0$ & 34.691600 & -76.471750 \\
\hline $15-1$ & 34.691767 & -76.472067 \\
\hline $15-2$ & 34.691900 & -76.472333 \\
\hline $16-0$ & 34.698417 & -76.466133 \\
\hline $16-1$ & 34.698550 & -76.466417 \\
\hline $16-2$ & 34.698750 & -76.466700 \\
\hline $17-1$ & 34.705217 & -76.460567 \\
\hline $17-2$ & 34.705350 & -76.460767 \\
\hline $18-2$ & 34.711983 & -76.454833 \\
\hline $19-1$ & 34.718450 & -76.448650 \\
\hline $19-2$ & 34.718617 & -76.448917 \\
\hline $21-1$ & 34.731717 & -76.436783 \\
\hline $21-2$ & 34.731900 & -76.437067 \\
\hline $22-2$ & 34.738517 & -76.431167 \\
\hline $23-2$ & 34.745167 & -76.425217 \\
\hline $24-2$ & 34.751800 & -76.419283 \\
\hline $25-2$ & 34.758500 & -76.413433 \\
\hline $27-1$ & 34.771533 & -76.401233 \\
\hline $27-2$ & 34.771717 & -76.401500 \\
\hline $28-1$ & 34.778183 & -76.395283 \\
\hline $28-2$ & 34.778400 & -76.395550 \\
\hline $29-0$ & 34.784483 & -76.388383 \\
\hline $29-1$ & 34.784833 & -76.389317 \\
\hline $29-2$ & 34.785017 & -76.389583 \\
\hline
\end{tabular}


Appendix 5. Latitude and longitude for the recovered U.S. Army Corps of Engineers (1964) reference markers and that were resurveyed in 2001 by East Carolina University for the present study on Core Banks, Cape Lookout National Seashore, North Carolina.-Continued

[1-0 represents profile $\mathrm{P} 1$, and reference marker RM-0; 2-2 represents profile $\mathrm{P} 2$, and reference marker RM-2]

\begin{tabular}{|c|c|c|}
\hline \multicolumn{3}{|c|}{ Reference markers recovered in 2001} \\
\hline Reference marker & $\begin{array}{c}\text { Latitude north } \\
\text { decimal degrees }\end{array}$ & $\begin{array}{l}\text { Longitude west } \\
\text { decimal degrees }\end{array}$ \\
\hline $30-1$ & 34.791000 & -76.382717 \\
\hline $30-2$ & 34.791200 & -76.382967 \\
\hline $31-1$ & 34.797183 & -76.376083 \\
\hline $31-2$ & 34.797400 & -76.376367 \\
\hline $32-1$ & 34.803383 & -76.369467 \\
\hline $32-2$ & 34.803533 & -76.369733 \\
\hline $33-1$ & 34.809550 & -76.362867 \\
\hline $33-2$ & 34.809717 & -76.363100 \\
\hline $34-2$ & 34.815900 & -76.356483 \\
\hline $42-4$ & 34.864917 & -76.302950 \\
\hline $42-6$ & 34.865267 & -76.303433 \\
\hline $43-0$ & 34.870133 & -76.295117 \\
\hline $46-1$ & 34.886467 & -76.272767 \\
\hline $47-1$ & 34.891767 & -76.265167 \\
\hline $47-2$ & 34.892000 & -76.265350 \\
\hline $49-1$ & 34.902767 & -76.250217 \\
\hline $49-2$ & 34.902967 & -76.250450 \\
\hline $49-4$ & 34.903350 & -76.250900 \\
\hline $50-2$ & 34.908817 & -76.243367 \\
\hline $51-1$ & 34.914300 & -76.235867 \\
\hline $51-2$ & 34.914533 & -76.236133 \\
\hline $52-1$ & 34.920333 & -76.229017 \\
\hline $52-2$ & 34.920533 & -76.229267 \\
\hline $53-0$ & 34.925950 & -76.221717 \\
\hline $53-1$ & 34.926183 & -76.221983 \\
\hline $53-2$ & 34.926350 & -76.222217 \\
\hline
\end{tabular}

Appendix 5. Latitude and longitude for the recovered U.S. Army Corps of Engineers (1964) reference markers and that were resurveyed in 2001 by East Carolina University for the present study on Core Banks, Cape Lookout National Seashore, North Carolina.-Continued

[1-0 represents profile $\mathrm{P}$ 1, and reference marker RM-0; 2-2 represents profile $\mathrm{P} 2$, and reference marker RM-2]

\begin{tabular}{|c|c|c|}
\hline \multicolumn{3}{|c|}{ Reference markers recovered in 2001} \\
\hline Reference marker & $\begin{array}{l}\text { Latitude north } \\
\text { decimal degrees }\end{array}$ & $\begin{array}{l}\text { Longitude west } \\
\text { decimal degrees }\end{array}$ \\
\hline $54-1$ & 34.932033 & -76.214917 \\
\hline $54-2$ & 34.932200 & -76.215167 \\
\hline $54-4$ & 34.932617 & -76.215633 \\
\hline $55-2$ & 34.938083 & -76.208133 \\
\hline $55-4$ & 34.938450 & -76.208600 \\
\hline $55-6$ & 34.938883 & -76.209067 \\
\hline $56-1$ & 34.943717 & -76.200817 \\
\hline $56-2$ & 34.943917 & -76.201050 \\
\hline $58-0$ & 34.955200 & -76.186467 \\
\hline $58-1$ & 34.955400 & -76.186717 \\
\hline $58-4$ & 34.955983 & -76.187417 \\
\hline $59-0$ & 34.961033 & -76.179400 \\
\hline $59-1$ & 34.961250 & -76.179650 \\
\hline $59-2$ & 34.961450 & -76.179883 \\
\hline $60-0$ & 34.966667 & -76.172083 \\
\hline $60-1$ & 34.966867 & -76.172317 \\
\hline $60-2$ & 34.967067 & -76.172550 \\
\hline $61-0$ & 34.972283 & -76.164767 \\
\hline $61-1$ & 34.972500 & -76.165000 \\
\hline $61-2$ & 34.972683 & -76.165217 \\
\hline $62-0$ & 34.978700 & -76.158350 \\
\hline $63-0$ & 34.983533 & -76.150083 \\
\hline $63-1$ & 34.983817 & -76.150367 \\
\hline $63-2$ & 34.983933 & -76.150583 \\
\hline $64-0$ & 34.989183 & -76.142767 \\
\hline $64-1$ & 34.989367 & -76.143017 \\
\hline $64-2$ & 34.989567 & -76.143233 \\
\hline $64-4$ & 34.989967 & -76.143717 \\
\hline
\end{tabular}


Appendix 5. Latitude and longitude for the recovered U.S. Army Corps of Engineers (1964) reference markers and that were resurveyed in 2001 by East Carolina University for the present study on Core Banks, Cape Lookout National Seashore, North Carolina.-Continued

[1-0 represents profile $\mathrm{P} 1$, and reference marker RM-0; $2-2$ represents profile $\mathrm{P} 2$, and reference marker RM-2]

\begin{tabular}{|c|c|c|}
\hline \multicolumn{3}{|c|}{ Reference markers recovered in 2001} \\
\hline Reference marker & $\begin{array}{l}\text { Latitude north } \\
\text { decimal degrees }\end{array}$ & $\begin{array}{l}\text { Longitude west } \\
\text { decimal degrees }\end{array}$ \\
\hline $65-1$ & 34.994983 & -76.135700 \\
\hline $65-2$ & 34.995200 & -76.135917 \\
\hline $65-4$ & 34.995583 & -76.136383 \\
\hline $66-1$ & 35.000583 & -76.128367 \\
\hline $66-2$ & 35.000800 & -76.128600 \\
\hline $66-4$ & 35.001183 & -76.129050 \\
\hline $68-4$ & 35.012450 & -76.114367 \\
\hline $69-1$ & 35.017150 & -76.105933 \\
\hline $69-2$ & 35.017300 & -76.106117 \\
\hline $70-4$ & 35.022933 & -76.098800 \\
\hline $71-4$ & 35.028183 & -76.091017 \\
\hline $71-6$ & 35.028583 & -76.091467 \\
\hline $71-8$ & 35.028983 & -76.091967 \\
\hline $72-0$ & 35.034233 & -76.084133 \\
\hline 73-4 & 35.038600 & -76.075500 \\
\hline $73-6$ & 35.039000 & -76.075950 \\
\hline $73-8$ & 35.039450 & -76.076367 \\
\hline $74-4$ & 35.043800 & -76.067767 \\
\hline $74-6$ & 35.044250 & -76.068200 \\
\hline
\end{tabular}


Appendix 6. Summary of the East Carolina University survey data developed for 57 of the 77 U.S. Army Corps of Engineers profiles located in the 2001 survey on Core Banks, Cape Lookout National Seashore, North Carolina.

[USACE, U.S. Army Corps of Engineers; RM, reference marker; ft, feet; MSL, mean sea level; NL, not located; --, no data. Columns A through G are located in appendix 1]

\begin{tabular}{|c|c|c|c|c|c|}
\hline $\begin{array}{l}\text { (H) USACE } \\
\text { reference } \\
\text { marker }\end{array}$ & $\begin{array}{l}\text { (I) } 2001 \text { distance } \\
\text { measured (ft) from } \\
\text { located RM-X to } \\
\text { MSL (1929 datum) }\end{array}$ & $\begin{array}{l}\text { (J) Erosion (ft) from } \\
1960 \text { through } 2001 \\
\text { (columns E-I) }\end{array}$ & $\begin{array}{l}\text { (K) } 2001 \text { ground elevation } \\
\text { (ft) above or below top of } \\
\text { USACE reference marker }\end{array}$ & $\begin{array}{l}\text { (L) } 2001 \text { ground } \\
\text { elevation (ft) above } \\
\text { MSL (1929 datum) } \\
\text { (columns C+K) }\end{array}$ & $\begin{array}{l}\text { (M) Change in surface } \\
\text { elevation between } \\
1961 \text { and } 2001 \text { (ft above } \\
\text { MSL } 1929 \text { datum) } \\
\text { (columns L-D) }\end{array}$ \\
\hline 1-0 & NL & -- & -- & - & -- \\
\hline $1-1$ & NL & -- & -- & -- & -- \\
\hline $1-2$ & NL & -- & -- & -- & -- \\
\hline $2-0$ & NL & -- & -- & -- & -- \\
\hline $2-1$ & NL & -- & -- & -- & -- \\
\hline $2-2$ & 292 & 183 & 4.5 & 17.7 & 6.10 \\
\hline 3-0 & NL & -- & -- & -- & -- \\
\hline $3-1$ & NL & -- & -- & -- & -- \\
\hline $3-2$ & NL & -- & -- & -- & -- \\
\hline $4-0$ & NL & -- & -- & -- & -- \\
\hline $4-1$ & 155 & 205 & -- & -- & -- \\
\hline $4-2$ & 255 & 205 & -- & -- & -- \\
\hline $5-0$ & NL & -- & -- & -- & -- \\
\hline $5-1$ & NL & -- & -- & -- & -- \\
\hline $5-2$ & 210 & 300 & 4.6 & 10.7 & 5.16 \\
\hline $5-4$ & 410 & 300 & 3.5 & 8.6 & 4.42 \\
\hline 6-0 & 343 & 87 & 3.8 & 10.0 & 4.49 \\
\hline 6-1 & 443 & 87 & 2.9 & 8.9 & 3.63 \\
\hline $6-2$ & 543 & 87 & 1.3 & 8.4 & 1.90 \\
\hline $7-0$ & 305 & 135 & 3.1 & 10.8 & 3.76 \\
\hline $7-1$ & 405 & 135 & 3.4 & 10.9 & 4.08 \\
\hline $7-2$ & 505 & 135 & 2 & 9.4 & 2.83 \\
\hline 8-0 & NL & -- & -- & -- & -- \\
\hline 8-1 & 351 & 79 & 4.8 & 11.4 & 5.35 \\
\hline $8-2$ & 451 & 79 & 3.5 & 9.9 & 4.24 \\
\hline $9-0$ & NL & -- & -- & -- & -- \\
\hline $9-1$ & 242 & 23 & 3.6 & 11.3 & 4.36 \\
\hline $9-2$ & 342 & 23 & 3.1 & 10.1 & 3.85 \\
\hline $10-0$ & NL & -- & -- & -- & -- \\
\hline $10-1$ & 214 & 141 & 3.9 & 11.7 & 4.77 \\
\hline $10-2$ & 314 & 141 & 3.1 & 9.9 & 4.02 \\
\hline
\end{tabular}


Appendix 6. Summary of the East Carolina University survey data developed for 57 of the 77 U.S. Army Corps of Engineers profiles located in the 2001 survey on Core Banks, Cape Lookout National Seashore, North Carolina._Continued

[USACE, U.S. Army Corps of Engineers; RM, reference marker; ft, feet; MSL, mean sea level; NL, not located; --, no data. Columns A through G are located in appendix 1]

\begin{tabular}{|c|c|c|c|c|c|}
\hline $\begin{array}{l}\text { (H) USACE } \\
\text { reference } \\
\text { marker }\end{array}$ & $\begin{array}{l}\text { (I) } 2001 \text { distance } \\
\text { measured (ft) from } \\
\text { located RM-X to } \\
\text { MSL (1929 datum) }\end{array}$ & $\begin{array}{l}\text { (J) Erosion (ft) from } \\
1960 \text { through } 2001 \\
\text { (columns E-I) }\end{array}$ & $\begin{array}{l}\text { (K) } 2001 \text { ground elevation } \\
\text { (ft) above or below top of } \\
\text { USACE reference marker }\end{array}$ & $\begin{array}{l}\text { (L) } 2001 \text { ground } \\
\text { elevation (ft) above } \\
\text { MSL (1929 datum) } \\
\text { (columns C+K) }\end{array}$ & $\begin{array}{l}\text { (M) Change in surface } \\
\text { elevation between } \\
1961 \text { and } 2001 \text { (ft above } \\
\text { MSL } 1929 \text { datum) } \\
\text { (columns L-D) }\end{array}$ \\
\hline $11-0$ & 390 & 55 & 4.7 & 11.5 & 5.33 \\
\hline $11-1$ & 490 & 55 & 4 & 10.8 & 4.63 \\
\hline $12-0$ & 352 & 38 & 4.6 & 11.8 & 5.09 \\
\hline $12-1$ & 452 & 38 & 3.2 & 9.9 & 3.81 \\
\hline $12-2$ & 552 & 38 & 3 & 9.7 & 3.70 \\
\hline $14-0$ & 420 & 70 & 3.1 & 9.3 & 3.66 \\
\hline $14-1$ & 520 & 70 & 2.5 & 7.7 & 3.22 \\
\hline $14-2$ & 620 & 70 & 1.2 & 5.9 & 1.99 \\
\hline $15-0$ & 420 & 45 & 4.5 & 10.7 & 5.06 \\
\hline $15-1$ & 520 & 45 & 4 & 9.4 & 4.72 \\
\hline $15-2$ & 620 & 45 & 3.6 & 8.3 & 4.34 \\
\hline $16-0$ & 380 & 85 & 3.7 & 10.8 & 4.57 \\
\hline $17-2$ & 455 & 140 & 2.5 & 8.6 & 2.35 \\
\hline $18-0$ & NL & -- & -- & -- & -- \\
\hline $18-1$ & NL & -- & -- & -- & -- \\
\hline $18-2$ & 200 & 375 & 3.2 & 9.7 & 3.96 \\
\hline $19-0$ & NL & -- & -- & -- & -- \\
\hline $19-1$ & 414 & 126 & 1.6 & 8.4 & 2.35 \\
\hline $19-2$ & 514 & 126 & 1 & 7.6 & 1.92 \\
\hline $20-0$ & NL & -- & -- & -- & -- \\
\hline $20-1$ & NL & -- & -- & -- & -- \\
\hline $20-2$ & NL & -- & -- & -- & -- \\
\hline $21-0$ & NL & -- & -- & -- & -- \\
\hline $21-1$ & 270 & 115 & 3.3 & 10.7 & 3.96 \\
\hline $21-2$ & 370 & 115 & 2.4 & 9.0 & 3.15 \\
\hline
\end{tabular}


Appendix 6. Summary of the East Carolina University survey data developed for 57 of the 77 U.S. Army Corps of Engineers profiles located in the 2001 survey on Core Banks, Cape Lookout National Seashore, North Carolina.-Continued

[USACE, U.S. Army Corps of Engineers; RM, reference marker; ft, feet; MSL, mean sea level; NL, not located; --, no data. Columns A through G are located in appendix 1]

\begin{tabular}{|c|c|c|c|c|c|}
\hline $\begin{array}{l}\text { (H) USACE } \\
\text { reference } \\
\text { marker }\end{array}$ & $\begin{array}{l}\text { (I) } 2001 \text { distance } \\
\text { measured (ft) from } \\
\text { located RM-X to } \\
\text { MSL (1929 datum) }\end{array}$ & $\begin{array}{l}\text { (J) Erosion (ft) from } \\
1960 \text { through } 2001 \\
\text { (columns E-I) }\end{array}$ & $\begin{array}{l}\text { (K) } 2001 \text { ground elevation } \\
\text { (ft) above or below top of } \\
\text { USACE reference marker }\end{array}$ & $\begin{array}{l}\text { (L) } 2001 \text { ground } \\
\text { elevation }(\mathrm{ft}) \text { above } \\
\text { MSL (1929 datum) } \\
\text { (columns C+K) }\end{array}$ & $\begin{array}{l}\text { (M) Change in surface } \\
\text { elevation between } \\
1961 \text { and } 2001 \text { (ft above } \\
\text { MSL } 1929 \text { datum) } \\
\text { (columns L-D) }\end{array}$ \\
\hline $22-0$ & $\mathrm{NL}$ & -- & -- & -- & -- \\
\hline $22-1$ & 355 & 90 & 2.8 & 10.5 & 1.71 \\
\hline $22-2$ & NL & -- & -- & -- & -- \\
\hline $23-0$ & NL & -- & -- & -- & -- \\
\hline $23-1$ & NL & -- & -- & -- & -- \\
\hline $23-2$ & 290 & 240 & 3.2 & 8.6 & 3.60 \\
\hline $24-0$ & NL & -- & -- & -- & -- \\
\hline 24-1 & NL & -- & -- & -- & -- \\
\hline $24-2$ & 300 & 265 & 1.6 & 7.2 & 2.04 \\
\hline $25-0$ & NL & -- & -- & -- & -- \\
\hline $25-1$ & NL & -- & -- & -- & -- \\
\hline $25-2$ & 420 & 210 & 2.1 & 7.2 & 2.90 \\
\hline $26-0$ & NL & -- & -- & -- & -- \\
\hline $26-1$ & NL & -- & -- & -- & -- \\
\hline $26-2$ & NL & -- & -- & -- & -- \\
\hline $27-0$ & NL & -- & -- & -- & -- \\
\hline $27-1$ & 450 & 130 & 1.4 & 7.1 & 2.21 \\
\hline $27-2$ & 550 & 130 & 2.6 & 7.7 & 3.12 \\
\hline $28-0$ & NL & -- & -- & -- & -- \\
\hline $28-1$ & 360 & 115 & -- & -- & -- \\
\hline $28-2$ & 460 & 115 & 3.25 & 9.4 & 4.00 \\
\hline $29-0$ & 440 & 25 & 6.9 & 14.4 & 7.06 \\
\hline $29-1$ & 540 & 25 & 4.65 & 11.3 & 5.42 \\
\hline $29-2$ & 640 & 25 & 2.1 & 8.1 & 2.95 \\
\hline $30-0$ & NL & -- & -- & -- & -- \\
\hline $30-1$ & 310 & 90 & 2.82 & 10.6 & 3.51 \\
\hline $30-2$ & 410 & 90 & 3.35 & 10.2 & 4.07 \\
\hline $31-0$ & NL & -- & -- & -- & -- \\
\hline $31-1$ & 290 & 125 & 3.86 & 11.7 & 4.60 \\
\hline $31-2$ & 390 & 125 & 5.65 & 12.6 & 6.37 \\
\hline $32-0$ & NL & -- & -- & -- & -- \\
\hline $32-1$ & 330 & 110 & 2.5 & 11.3 & 3.35 \\
\hline $32-2$ & 430 & 110 & 2.24 & 10.3 & 2.99 \\
\hline
\end{tabular}


Appendix 6. Summary of the East Carolina University survey data developed for 57 of the 77 U.S. Army Corps of Engineers profiles located in the 2001 survey on Core Banks, Cape Lookout National Seashore, North Carolina._Continued

[USACE, U.S. Army Corps of Engineers; RM, reference marker; ft, feet; MSL, mean sea level; NL, not located; --, no data. Columns A through G are located in appendix 1]

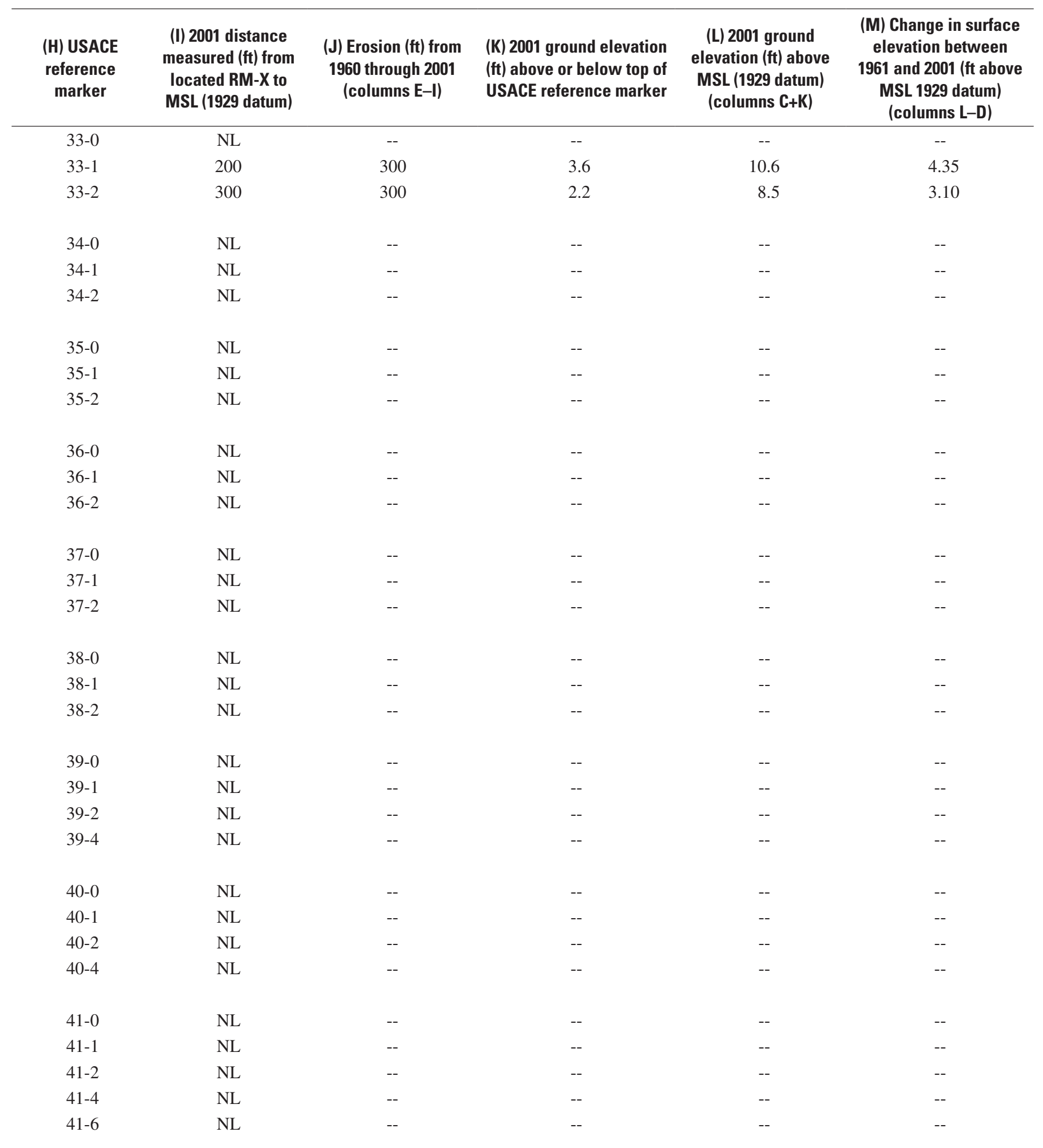


Appendix 6. Summary of the East Carolina University survey data developed for 57 of the 77 U.S. Army Corps of Engineers profiles located in the 2001 survey on Core Banks, Cape Lookout National Seashore, North Carolina.-Continued

[USACE, U.S. Army Corps of Engineers; RM, reference marker; ft, feet; MSL, mean sea level; NL, not located; --, no data. Columns A through G are located in appendix 1]

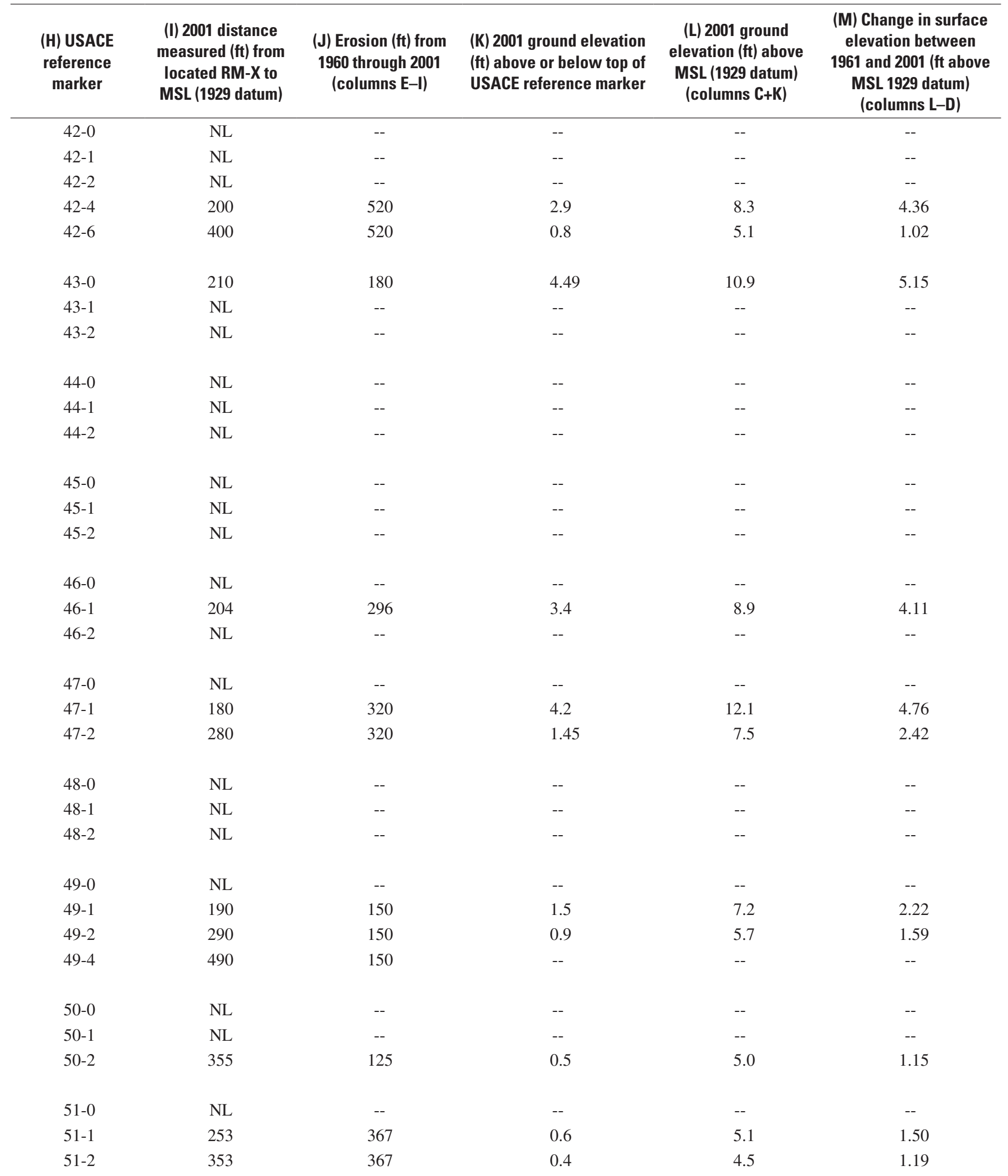


Appendix 6. Summary of the East Carolina University survey data developed for 57 of the 77 U.S. Army Corps of Engineers profiles located in the 2001 survey on Core Banks, Cape Lookout National Seashore, North Carolina.-Continued

[USACE, U.S. Army Corps of Engineers; RM, reference marker; ft, feet; MSL, mean sea level; NL, not located; --, no data. Columns A through G are located in appendix 1]

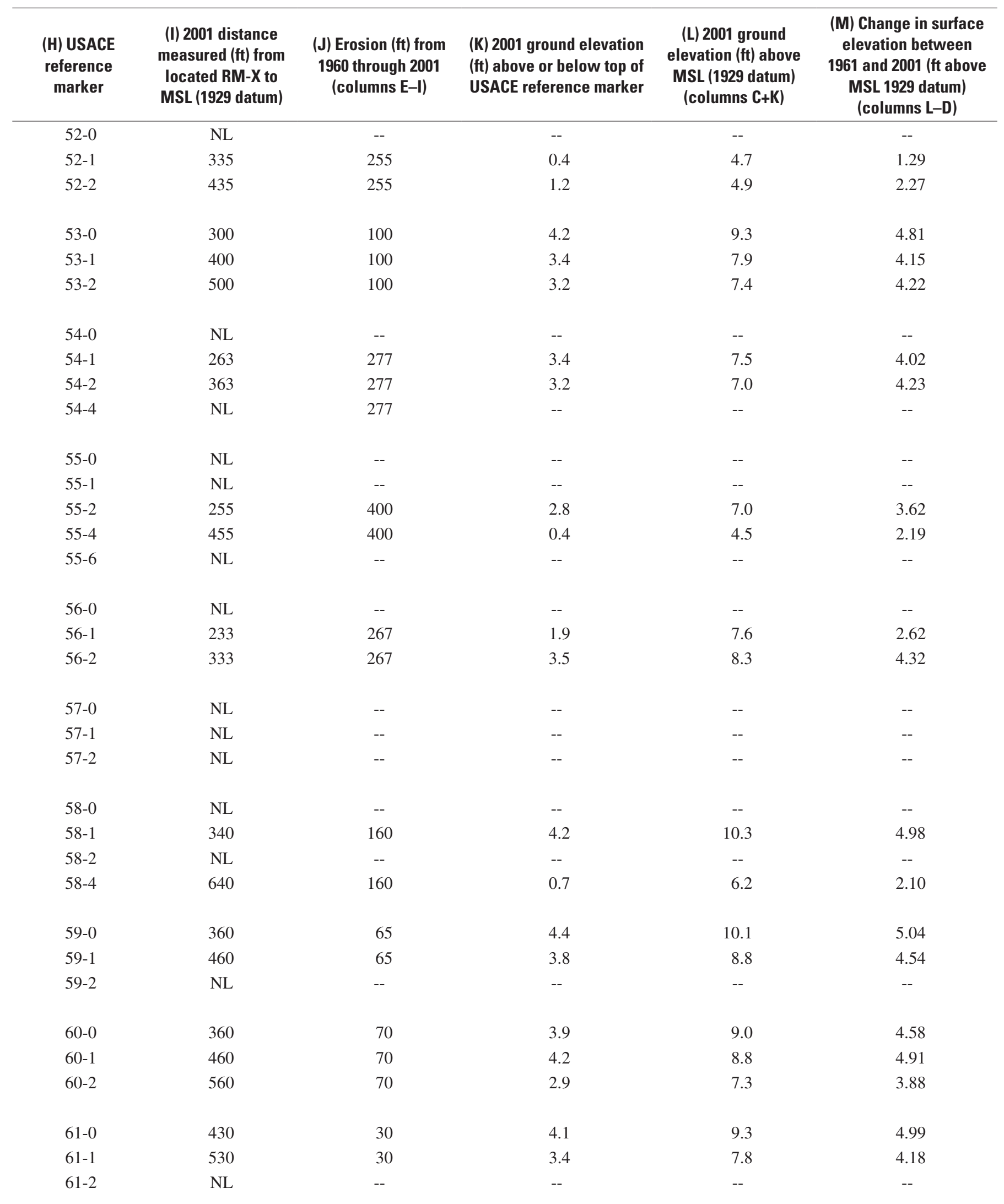


Appendix 6. Summary of the East Carolina University survey data developed for 57 of the 77 U.S. Army Corps of Engineers profiles located in the 2001 survey on Core Banks, Cape Lookout National Seashore, North Carolina.-Continued

[USACE, U.S. Army Corps of Engineers; RM, reference marker; ft, feet; MSL, mean sea level; NL, not located; --, no data. Columns A through G are located in appendix 1]

\begin{tabular}{|c|c|c|c|c|c|}
\hline $\begin{array}{l}\text { (H) USACE } \\
\text { reference } \\
\text { marker }\end{array}$ & $\begin{array}{l}\text { (I) } 2001 \text { distance } \\
\text { measured (ft) from } \\
\text { located RM-X to } \\
\text { MSL (1929 datum) }\end{array}$ & $\begin{array}{l}\text { (J) Erosion (ft) from } \\
1960 \text { through } 2001 \\
\text { (columns E-l) }\end{array}$ & $\begin{array}{l}\text { (K) } 2001 \text { ground elevation } \\
\text { (ft) above or below top of } \\
\text { USACE reference marker }\end{array}$ & $\begin{array}{l}\text { (L) } 2001 \text { ground } \\
\text { elevation (ft) above } \\
\text { MSL (1929 datum) } \\
\text { (columns C+K) }\end{array}$ & $\begin{array}{l}\text { (M) Change in surface } \\
\text { elevation between } \\
1961 \text { and } 2001 \text { (ft above } \\
\text { MSL } 1929 \text { datum) } \\
\text { (columns L-D) }\end{array}$ \\
\hline $62-0$ & $\mathrm{NL}$ & - & - & - & -- \\
\hline $62-1$ & 495 & 225 & -- & -- & -- \\
\hline $62-2$ & NL & -- & -- & -- & -- \\
\hline $62-4$ & $\mathrm{NL}$ & -- & -- & -- & -- \\
\hline 63-0 & 422 & 203 & 3.5 & 7.7 & 4.39 \\
\hline $63-1$ & NL & -- & -- & -- & -- \\
\hline $63-2$ & NL & -- & -- & -- & -- \\
\hline 64-0 & $\mathrm{NL}$ & -- & -- & -- & -- \\
\hline $64-1$ & 421 & 179 & 2 & 6.8 & 2.66 \\
\hline $64-2$ & $\mathrm{NL}$ & -- & -- & -- & -- \\
\hline 64-4 & NL & -- & -- & -- & -- \\
\hline $65-0$ & NL & -- & -- & -- & -- \\
\hline $65-1$ & 390 & 290.0 & 3.5 & 8.3 & 4.06 \\
\hline $65-2$ & NL & -- & -- & -- & -- \\
\hline $65-4$ & NL & -- & -- & -- & -- \\
\hline $66-0$ & NL & -- & -- & -- & -- \\
\hline 66-1 & 451 & 349 & 4.5 & 8.7 & 5.19 \\
\hline $66-2$ & 551 & 349 & 3.2 & 7.0 & 3.91 \\
\hline $66-4$ & 751 & 349 & 2.6 & 6.7 & 4.21 \\
\hline $67-0$ & NL & -- & -- & -- & -- \\
\hline $67-1$ & NL & -- & -- & -- & -- \\
\hline $67-2$ & NL & -- & -- & -- & -- \\
\hline $67-4$ & NL & -- & -- & -- & -- \\
\hline $68-0$ & $\mathrm{NL}$ & -- & -- & -- & -- \\
\hline 68-1 & NL & -- & -- & -- & -- \\
\hline $68-2$ & NL & -- & -- & -- & -- \\
\hline 68-4 & 458 & 652 & 2.2 & 5.4 & 2.71 \\
\hline $68-6$ & NL & -- & -- & -- & -- \\
\hline 68-8 & NL & -- & -- & -- & -- \\
\hline 69-0 & NL & -- & -- & -- & -- \\
\hline $69-1$ & 352 & 328 & 5.1 & 10.5 & 6.22 \\
\hline $69-2$ & 452 & 328 & 0 & 4.7 & 1.22 \\
\hline
\end{tabular}


Appendix 6. Summary of the East Carolina University survey data developed for 57 of the 77 U.S. Army Corps of Engineers profiles located in the 2001 survey on Core Banks, Cape Lookout National Seashore, North Carolina.-Continued

[USACE, U.S. Army Corps of Engineers; RM, reference marker; ft, feet; MSL, mean sea level; NL, not located; --, no data. Columns A through G are located in appendix 1]

\begin{tabular}{|c|c|c|c|c|c|}
\hline $\begin{array}{l}\text { (H) USACE } \\
\text { reference } \\
\text { marker }\end{array}$ & $\begin{array}{l}\text { (I) } 2001 \text { distance } \\
\text { measured (ft) from } \\
\text { located RM-X to } \\
\text { MSL (1929 datum) }\end{array}$ & $\begin{array}{l}\text { (J) Erosion (ft) from } \\
1960 \text { through } 2001 \\
\text { (columns E-I) }\end{array}$ & $\begin{array}{l}\text { (K) } 2001 \text { ground elevation } \\
\text { (ft) above or below top of } \\
\text { USACE reference marker }\end{array}$ & $\begin{array}{l}\text { (L) } 2001 \text { ground } \\
\text { elevation (ft) above } \\
\text { MSL (1929 datum) } \\
\text { (columns C+K) }\end{array}$ & $\begin{array}{l}\text { (M) Change in surface } \\
\text { elevation between } \\
1961 \text { and } 2001 \text { (ft above } \\
\text { MSL } 1929 \text { datum) } \\
\text { (columns L-D) }\end{array}$ \\
\hline $70-0$ & NL & -- & -- & -- & -- \\
\hline 70-1 & NL & -- & -- & -- & -- \\
\hline $70-2$ & NL & -- & -- & -- & -- \\
\hline $70-4$ & 621 & 279 & 2.9 & 7.1 & 5.13 \\
\hline $71-0$ & NL & -- & -- & -- & -- \\
\hline $71-1$ & NL & -- & -- & -- & -- \\
\hline $71-2$ & NL & -- & -- & -- & -- \\
\hline 71-4 & 32 & 768 & 4.6 & 9.4 & 6.28 \\
\hline $71-6$ & 232 & 768 & 1.8 & 5.8 & 3.08 \\
\hline 71-8 & 432 & 768 & 0.8 & 4.4 & 4.43 \\
\hline $72-0$ & NL & -- & -- & -- & -- \\
\hline $72-1$ & NL & -- & -- & -- & -- \\
\hline $72-2$ & NL & -- & -- & -- & -- \\
\hline $72-4$ & 118 & 622.0 & 0.7 & 5.9 & 2.64 \\
\hline $72-6$ & NL & -- & -- & -- & -- \\
\hline $72-8$ & NL & -- & -- & -- & -- \\
\hline $73-0$ & NL & -- & -- & -- & -- \\
\hline $73-1$ & NL & -- & -- & -- & -- \\
\hline $73-2$ & NL & -- & -- & -- & -- \\
\hline $73-4$ & NL & -- & -- & -- & -- \\
\hline $73-6$ & 304 & 626.0 & 1.8 & 5.7 & 5.69 \\
\hline 73-8 & 504 & 626.0 & 0 & 3.7 & 3.67 \\
\hline $74-0$ & NL & -- & -- & -- & -- \\
\hline $74-1$ & NL & -- & -- & -- & -- \\
\hline $74-2$ & NL & -- & -- & -- & -- \\
\hline $74-4$ & 194 & 606 & 0 & 4.8 & 1.82 \\
\hline $74-6$ & 394 & 606 & 1.1 & 5.4 & 5.43 \\
\hline $75-0$ & NL & -- & -- & -- & -- \\
\hline $75-1$ & NL & -- & -- & -- & -- \\
\hline $75-2$ & NL & -- & -- & -- & -- \\
\hline $76-0$ & NL & -- & -- & -- & -- \\
\hline $76-1$ & NL & -- & -- & -- & -- \\
\hline $76-2$ & NL & -- & -- & -- & -- \\
\hline $77-0$ & NL & -- & -- & -- & -- \\
\hline $77-1$ & NL & -- & -- & -- & -- \\
\hline $77-2$ & NL & -- & -- & -- & -- \\
\hline
\end{tabular}


Appendix 7. Summary of the North Carolina Division of Coastal Management (NCDCM) data for the average annual shoreline erosion rates on Core Banks, Cape Lookout National Seashore, North Carolina.

[USACE, U.S. Army Corps of Engineers; NCDCM, North Carolina Division of Coastal Management; ft/yr, feet per year; --, no data]

\begin{tabular}{|c|c|c|c|c|c|}
\hline $\begin{array}{c}\text { USACE profile } \\
\text { number }\end{array}$ & $\begin{array}{l}\text { NCDCM 1946-1998 } \\
\text { average annual } \\
\text { erosion rate (ft/yr) }\end{array}$ & $\begin{array}{c}\text { NCDCM 1940-1992 } \\
\text { average annual } \\
\text { erosion rate (ft/yr) }\end{array}$ & $\begin{array}{l}\text { USACE profile } \\
\text { number }\end{array}$ & $\begin{array}{c}\text { NCDCM 1946-1998 } \\
\text { average annual } \\
\text { erosion rate (ft/yr) }\end{array}$ & $\begin{array}{c}\text { NCDCM 1940-1992 } \\
\text { average annual } \\
\text { erosion rate (ft/yr) }\end{array}$ \\
\hline 1 & -6 & -7 & 41 & -6.5 & -12 \\
\hline 2 & -6 & -8 & 42 & -6 & -8 \\
\hline 3 & -6 & -8 & 43 & -3 & -4 \\
\hline 4 & -4 & -5 & 44 & -2 & -4 \\
\hline 5 & -2 & -5 & 45 & -2 & -2 \\
\hline 6 & -2 & -2 & 46 & -5.5 & -2 \\
\hline 7 & -2 & -2 & 47 & -4 & -4 \\
\hline 8 & -2 & -2 & 48 & -3 & -4 \\
\hline 9 & -2 & -2 & 49 & -4 & -5 \\
\hline 10 & -2 & -2 & 50 & -5 & -4 \\
\hline 11 & -3 & -2 & 51 & -5 & -4 \\
\hline 12 & -3 & -2 & 52 & -5 & -4 \\
\hline 13 & -3 & -2 & 53 & -5 & -4 \\
\hline 14 & -3.5 & -2 & 54 & -4 & -3 \\
\hline 15 & -2 & -2 & 55 & -5 & -4 \\
\hline 16 & -2 & -2 & 56 & -5.5 & -4 \\
\hline 17 & -2 & -2 & 57 & -5.5 & -4 \\
\hline 18 & -2 & -2 & 58 & -4 & -4 \\
\hline 19 & -2 & -2 & 59 & -3 & -4 \\
\hline 20 & -3 & -3 & 60 & -2 & -3 \\
\hline 21 & -4 & -3 & 61 & -2 & -2 \\
\hline 22 & -3 & -2 & 62 & -2 & -2 \\
\hline 23 & -3 & -2 & 63 & -6 & -3 \\
\hline 24 & -2.5 & -2 & 64 & -3 & -3 \\
\hline 25 & -2 & -2 & 65 & -3 & -2 \\
\hline 26 & -3 & -2 & 66 & -2 & -2 \\
\hline 27 & -4 & -2 & 67 & -2 & -2 \\
\hline 28 & -5 & -4 & 68 & -2 & -2 \\
\hline 29 & -4 & -2 & 69 & -4 & -2 \\
\hline 30 & -3 & -3 & 70 & -6 & -4 \\
\hline 31 & -3 & -3 & 71 & -7 & -6 \\
\hline 32 & -4 & -2 & 72 & -11 & -10 \\
\hline 33 & -5 & -2 & 73 & -12 & -10 \\
\hline 34 & -7 & -4.5 & 74 & -9.5 & -- \\
\hline 35 & -10.5 & -4.5 & 75 & -6.5 & -- \\
\hline 36 & -14 & -7.5 & 76 & -2 & -- \\
\hline 37 & -16 & -11.5 & 77 & -2 & -- \\
\hline 38 & -16.5 & -14.5 & & & \\
\hline 39 & -30 & -14.5 & & & \\
\hline 40 & -13.5 & -17 & & & \\
\hline
\end{tabular}

Appendix 7. Summary of the North Carolina Division of Coastal Management (NCDCM) data for the average annual shoreline erosion rates on Core Banks, Cape Lookout National Seashore, North Carolina.-Continued

[USACE, U.S. Army Corps of Engineers; NCDCM, North Carolina Division of Coastal Management; ft/yr, feet per year; --, no data] 
ISBN $978-1-411,3-19822-0$

4 Printed on recycled paper 